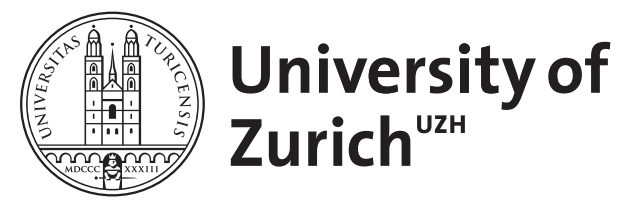

\title{
A revised classification of the Apocynaceae s.l.
}

\author{
Endress, Mary E ; Bruyns, Peter V
}

\begin{abstract}
The Asclepiadaceae, as traditionally defined, have repeatedly been shown to be an apomorphic derivative of the Apocynaceae. It has often been recommended that the Asclepiadaceae be subsumed within the Apocynaceae in order to make the latter monophyletic. To date, however, no comprehensive, unified classification has been established. Here we provide a unified classification for the Apocynaceae, which consists of 424 genera distributed among five subfamilies: Rauvolfioideae, Apocynoideae, Periplocoideae, Secamonoideae, and Asclepiadoideae. Keys to the subfamilies and tribes are provided, with lists of genera that (as far as we have been able to ascertain) are recognized in each tribe
\end{abstract}

DOI: https://doi.org/10.1007/bf02857781

Posted at the Zurich Open Repository and Archive, University of Zurich ZORA URL: https://doi.org/10.5167/uzh-156540

Journal Article

Published Version

Originally published at:

Endress, Mary E; Bruyns, Peter V (2000). A revised classification of the Apocynaceae s.l. Botanical Review, 66(1):1-56.

DOI: https://doi.org/10.1007/bf02857781 


\title{
THE BOTANICAL REVIEW \\ \begin{tabular}{lll} 
VOL. 66 & JANUARY-MARCH 2000 & No. 1 \\
\hline
\end{tabular}
}

\section{A Revised Classification of the Apocynaceae s.I.}

\author{
MARY E. ENDRESS \\ Institute of Systematic Botany \\ University of Zurich \\ 8008 Zurich, Switzerland \\ AND \\ PETER V. BRUYNS \\ Bolus Herbarium \\ University of Cape Town \\ Rondebosch 7700, South Africa
}

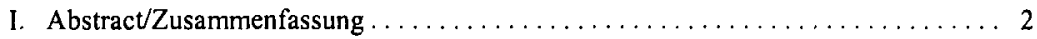

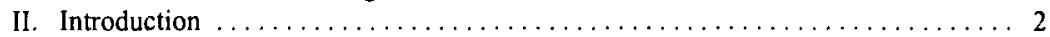

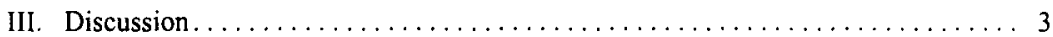

A. Infrafamilial Classification of the Apocynaceae s.str. ............. 3

B. Recognition of the Family Periplocaceae $\ldots \ldots \ldots \ldots \ldots \ldots \ldots \ldots$

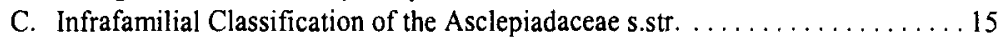

1. Recognition of the Secamonoideae ...................... 15

2. Relationships within the Asclepiadoideae .................. 17

D. Coronas within the Apocynaceae s.l.: Homologies and Interpretations . . . . . 22

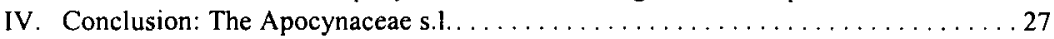

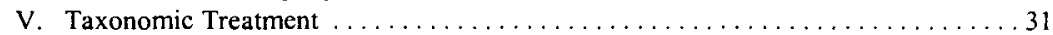

A. Key to the Subfamilies of the Apocynaceae $s .1 \ldots \ldots \ldots \ldots \ldots \ldots \ldots \ldots \ldots$

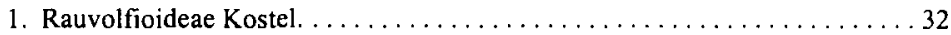

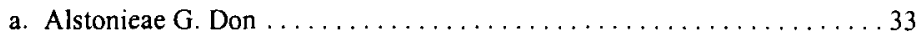

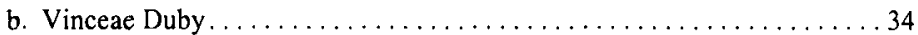

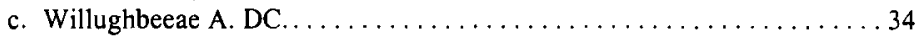

d. Tabernaemontaneae G. Don ............................. 35

e. Melodineae G. Don ............................. 36

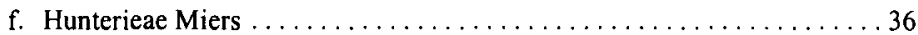

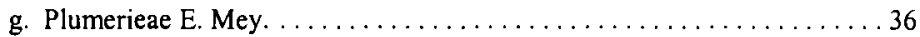

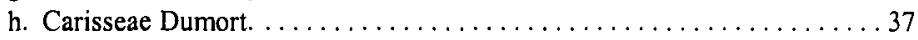

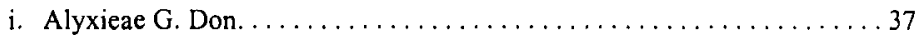

Copies of this issue [66(1)] may be purchased from the NYBG Press, The New York Botanical Garden, Bronx, NY 10458-5125, U.S.A. Please inquire as to prices. 


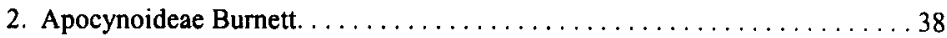

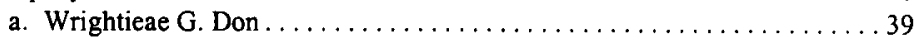

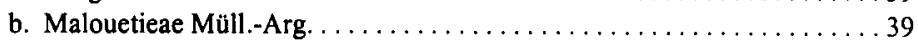

c. Apocyneae Rchb.............................. 40

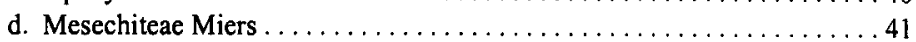

e. Echiteae Bartl. ............................... 41

3. Periplocoideae R. Br. ex Endl. ....................... 42

4. Secamonoideae Endl. ........................... 44

5. Asclepiadoideae R. Br. ex Burnett ..................... 45

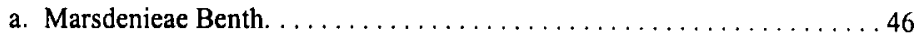

b. Ceropegieae Orb. ............................ 47

c. Asclepiadeae (R. Br.) Duby........................ 48

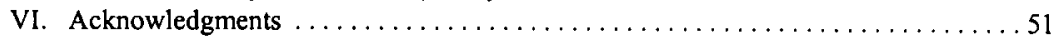

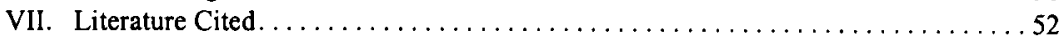

\section{Abstract}

The Asclepiadaceae, as traditionally defined, have repeatedly been shown to be an apomorphic derivative of the Apocynaceae. It has often been recommended that the Asclepiadaceae be subsumed within the Apocynaceae in order to make the latter monophyletic. To date, however, no comprehensive, unified classification has been established. Here we provide a unified classification for the Apocynaceae, which consists of 424 genera distributed among five subfamilies: Rauvolfioideae, Apocynoideae, Periplocoideae, Secamonoideae, and Asclepiadoideae. Keys to the subfamilies and tribes are provided, with lists of genera that (as far as we have been able to ascertain) are recognized in each tribe.

\section{Zusammenfassung}

Es wurde wiederholt festgestellt, dass die Asclepiadaceae in der traditionellen Umgrenzung ein apomorphes Derivat der Apocynaceae sind. Deshalb wurde oft vorgeschlagen, sie bei den Apocynaceae unterzubringen, damit die Apocynaceae eine monophyletische Gruppe darstellen. Bis jetzt wurde aber keine eingehende kombinierte Klassifikation publiziert. Hier stellen wir eine kombinierte Klassifikation vor für die Apocynaceae, mit 424 Gattungen, die in fünf Unterfamilien gegliedert sind: Rauvolfioideae, Apocynoideae, Periplocoideae, Secamonoideae und Asclepiadoideae. Schlüssel zu den Unterfamilien sowie den Triben werden gegeben. Die Gattungen, die zu jeder Tribus gehören (soweit bekannt) werden aufgelistet.

\section{Introduction}

In 1810 Robert Brown published two seminal papers, "Prodromus Flora Novae Hollandiae" (Brown, 1810a) and "On the Asclepiadeae" (Brown, 1810b). In these two publications Brown separated the Asclepiadeae (Asclepiadaceae) from the Apocineae (Apocynaceae) of Jussieu (1789) for the first time. In his Prodromus, which came out about a week before the second paper (Mabberley, 1985; Forster, 1991), he listed the taxa in two separate orders (families), which he called the Asclepiadeae and the Apocineae. His reasons for these changes were discussed in detail in the second paper: the main one being the presence of translators in the Asclepiadeae and their absence in the Apocyneae. Although Brown's classification has been universally accepted and implemented, controversy over the delimitation of 
the two families has never been put to rest. They are clearly more similar to each other than to the rest of the Gentianales, and in a number of characters there is a gradation from the Apocynaceae to the Asclepiadaceae. Three suggestions for recognition and expression of this relationship have appeared: as one family (Hallier, 1905; Demeter, 1922; Safwat, 1962; Stebbins, 1974; Stevens, 1976; Thorne, 1976, 1992; Judd et al., 1994; Struwe et al., 1994; Takhtajan, 1997); as an order separate from the Gentianales (Tsiang, 1934; Hutchinson, 1973); and as a suborder within the Gentianales (Rosatti, 1989; Nicholas \& Baijnath, 1994; Omlor, 1998).

None of these possibilities seems to have met with much acceptance, so that, more than 180 years after Brown's (1810b) treatise, the group is still usually maintained as two families in the Gentianales. Nevertheless, new evidence from more detailed and extensive morphological studies, as well as the rapidly growing body of molecular information (Judd et al., 1994; Endress \& Albert, 1995; Sennblad \& Bremer, 1996; Sennblad, 1997; Civeyrel et al., 1998; Sennblad et al., 1998; Potgieter, 1999), suggests that Brown's delimitation does not reflect natural relationships. This new information and cladistic interpretations of it support the recognition of a single entity.

Here we again assess the relationship between the Apocynaceae and the Asclepiadaceae, and we present our arguments for the recognition of a single family. A new classification is proposed, descriptions of taxa down to tribal level are provided, and the genera at present recognized in each tribe are listed. The priority rule has made necessary some changes of familiar names for subfamilies and tribes. We have adopted the oldest known names according to J. Reveal's Web site for suprageneric names (http://www.inform.umd.edu/PBIO). Thus some familiar names must be discarded. The major changes include: Rauvolfioideae Kostel. rather than Plumerioideae K. Schum.; Vinceae Duby rather than Rauvolfieae Bartl.; and Ceropegieae Orb. rather than Stapelieae Decne. Our classification is based mostly on morphological evidence accumulated through our own studies. Changes in classification based on results from molecular studies have been incorporated only where cladistic support was strong, or if they were also corroborated by morphological evidence.

\section{Discussion}

\section{A. INFRAFAMILIAL CLASSIFICATION OF THE APOCYNACEAE S.STR.}

The infrafamilial classification of the Apocynaceae s.str. has not changed much in the last 50 years. Two subfamilies are usually recognized: the Plumerioideae (= Rauvolfioideae), and the Apocynoideae. Additional subfamilies, such as Tabernaemontanoideae Stapf (1902), Apocynoideae sensu Woodson (1930), Cerberoideae Pichon (1948b), Carissoideae Endlicher (1838), have been described. However, either their delimitation is more ambiguous than that of the Rauvolfioideae and Apocynoideae, or they are at variance with our data. Consequently, they are not recognized here. The Rauvolfioideae typically have the corolla lobes sinistrorsely contorted in bud, the anthers are mostly unspecialized and free from the style head, and there is a broad array of fruit and seed types, although the seeds are almost always ecomose. The Apocynoideae, in contrast, are characterized by having the corolla lobes dextrorsely contorted in bud and anthers specialized with lignified guide rails and adnate to the style head, forming a gynostegium (Fig. 1); the fruit is almost always a dry follicle with comose seeds. With the exception of Woodson's (1930) backward hypothesis, the Rauvolfioideae have usually been considered to be basal and more heterogeneous than the Apocynoideae. This view is also supported in all molecular investigations of the group and is followed here. 


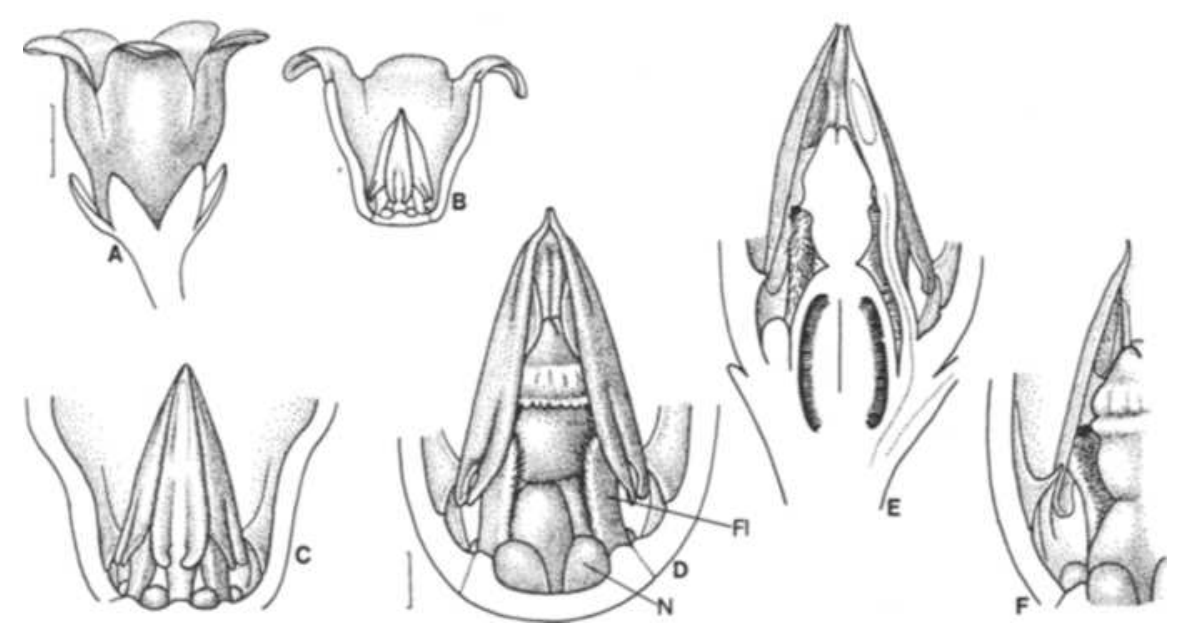

Fig. 1. Apocynoideae with filaments fused to corolla more or less at base, without any staminal foot: Apocynum androsaemifolium (M. Endress). A. Flower. B. Dissected flower with two petals removed. C. Gynostegium. D. Base of dissected flower with one stamen removed. E. Half-flower (base only). F. Base of flower with stamen removed, showing small "corona lobe" on corolla (located below middle of each petal and pointing up into base of guide rail). $\mathrm{FI}=$ filament; $\mathrm{N}=$ nectary. Scales: $\mathrm{A}, \mathrm{B}, 2 \mathrm{~mm}$ (at A); C, $1 \mathrm{~mm}$ (at A); D-F, $0.5 \mathrm{~mm}$ (at D).

The taxa of the Rauvolfioideae contain the least specialized flowers in the family. With the exception of the Tabernaemontaneae, which are characterized by the presence of lignified guide rails on the anthers, there are few distinguishing floral characters useful for differentiating among tribes. The flowers are typically small and whitish and have a salveriform corolla tube. The anthers are small and ovate and are not adnate to the style head.

Allorge (1975) reported a retinacle in Allamanda and transferred the genus to the Echitoideae (= Apocynoideae). However, the presence of a retinacle has not been confirmed in subsequent studies (Fallen, 1985), and a position in the Apocynoideae was not supported in more recent analyses either (Endress et al., 1996; Sennblad, 1997; Civeyrel et al., 1998). Leeuwenberg $(1991,1994)$ erroneously described Voacanga as having the anthers united with the style head because the style and style head are shed with the corolla. More careful investigations reveal that the style and style head come off when the corolla is shed not because the style head is united with the anthers but because of the conspicuously twisted corolla tube and the very large style head. On the inside of the corolla tube, the twisting in the tube manifests itself as tightly spiraled ridges that protrude into the corolla tube and reduce its diameter to much less than that of the enlarged style head. Thus, when the corolla is shed the ridges cannot pass over the style head and break it off instead. The only genus in the Rauvolfioideae in which the style head is united with any other structure is Thevetia. In at least some species of this genus the style head is postgenitally united with infrastaminal appendages of the corolla tube, below the anther. This union is not considered to be homologous to the retinacle and has been discussed elsewhere (Endress et al., 1996).

Thus, the very useful characters in the Apocynoideae provided by the structure of the retinacle are not found in the Rauvolfioideae. Obvious differences in floral structure characterize certain alliances but break down at tribal level. In constructing a tribal classification for 
the Rauvolfioideae, the systematist is faced with the dilemma of trying to find stable floral characters to distinguish the tribes amid a sea of monotonously similar flowers. For this reason tribal delimitation in the Rauvolfioideae has almost always been based on fruit characters.

At first glance this seems like an excellent solution, because the fruits are distinctive and allow taxa to be easily categorized and keys constructed. Current knowledge, however, suggests that these fruit-based classifications are overly simplistic. As noted earlier (Fallen, 1983a, 1983b), it is always risky to place too much weight on a single character, especially when that character is more than usually subject to selective pressure. Recent studies (Endress et al., 1996; Sennblad \& Bremer, 1996; Sennblad, 1997) indicate that fleshy, indehiscent fruits have evolved at least three times in the Rauvolfioideae. In addition, there are isolated cases of a taxon with fleshy, indehiscent fruits in a tribe that is otherwise characterized by dehiscent fruits with a dry pericarp and winged seeds. (Examples include Geissospermum (fruit a berry) and Vallesia and Microplumeria (fruit a drupe)-all closely related to Aspidosperma, which has dry, woody follicles and flat seeds with a diaphanous wing (Potgieter \& Albert, 1997, 1998a; Potgieter, 1999)-and Melodinus (fruit a berry), which is closely related to Diplorhynchus and other, related, dry-fruited genera. This suggests a strong oscillatory or "back-and-forth" evolution between fleshy and dry, dehiscent and indehiscent fruits in response to dispersal by water, wind, or animals. Similar recurrences of certain characters in various angiosperm families has been reported by Armbruster (1996), Endress (1996), and Hufford (1997). The fruit characters should continue to be used, but with caution and only in conjunction with other characters. These fruit characters have been used so long that systematists have become lazy and do not search for new, meaningful characters. This is precisely what is now needed. In this paper we attempt to remedy this by delimiting the tribes of the Rauvolfioideae to reflect more accurately their true relationships. However, a consequence of this is that they are no longer as neatly and precisely defined as they were in older classifications.

The most comprehensive survey of the Rauvolfioideae was that of Pichon (1948a, 1948b, $1949,1950 \mathrm{~b}$ ). It contained much new and detailed information and was a significant improvement over the classification published by Schumann (1895). However, tribes were still mostly based on a single fruit character. Pichon's ideas still dominate in floras and classifications today. For example, the most recent classification of Leeuwenberg (1994) scarcely differs from that of Pichon. Because they have been used for so long and the names are familiar, the tribes as recognized by Pichon and Leeuwenberg (cited above) will usually be outlined first (the names in quotation marks) in the discussion below, followed by the changes presented in the classification proposed here.

Pichon (1948a, 1948b, 1949, 1950b) split the rauvolfioid tribes into two main groups, depending on whether the inner pericarp was fleshy or dry. The first group contained the "Carisseae," "Ambelanieae" and "Macoubeeae" (fruit a fleshy, indehiscent berry) and the "Chilocarpeae" and "Tabernaemontaneae" (fruit consisting of dehiscent follicles with arillate seeds). The second group contained the "Alstonieae" (= "Plumerieae" sensu Leeuwenberg, 1994) (fruit a pair of dehiscent follicles with dry pericarp and usually winged seeds), "Rauvolfieae" (= "Alyxieae" sensu Leeuwenberg, 1994) (fruit an indehiscent drupe with a stony endocarp), and the "Allamandeae" (fruit a spiny unilocular capsule).

Syncarpy has generally been considered the plesiomorphic condition in the family, and the "Carisseae" was thus considered the most basal tribe. However, recent molecular results (Civeyrel, 1996; Endress et al., 1996; Sennblad \& Bremer, 1996; Sennblad, 1997; Civeyrel et al., 1998) suggest that the traditionally defined "Carisseae" is not a natural group and that syncarpy is perhaps not the basal condition in the family after all (Endress et al., 1996; Potgieter, 
1999). Rather, it appears that syncarpy has arisen independently in various assemblages and is, thus, not a particularly reliable character upon which to base a tribe. In the present treatment, the traditional "Carisseae" is split into three tribes. Carissa and Acokanthera form the new Carisseae. Morphologically they are distinguished by having placentas that become indurated in the fruit, forming a woody partition, as opposed to the remainder of the "Carisseae," in which the placentas are unspecialized or pulpy in the fruit. The "Pleiocarpinae," characterized by apocarpous ovaries and conspicuous gaps in the corolla tube just above insertion of the stamens, is removed from the "Carisseae" and is treated as a separate tribe- the Hunterieae - as was proposed earlier (Fallen, 1986, as Pleiocarpeae). The remainder of the "Carisseae" (excluding Melodinus) is, for the time being, maintained together as the tribe Willughbeeae. The monotypic "Chilocarpeae" is abandoned and Chilocarpus included in a newly defined Alyxieae.

The other two tribes with indehiscent fruits and a fleshy inner pericarp recognized by Pichon (1948a) and Leeuwenberg (1994), the "Ambelanieae" and the "Macoubeeae," differ from the "Carisseae" in having specialized anthers with winglike margins formed into hard, lignified guide rails, such as are found in the Tabernaemontaneae as traditionally defined. Although the "Ambelanieae" and "Macoubeeae" have a syncarpous ovary and seeds embedded in pulp, whereas in the Tabernaemontaneae the ovary is usually apocarpous and the seeds displayed with (often brightly colored) arils, the close relationship of these three tribes is well supported by morphological, chemical, and molecular evidence (Fallen, 1986; Zhu et al., 1990; Endress et al., 1996; Sennblad \& Bremer, 1996; Sennblad, 1997; Civeyrel et al., 1998). Therefore, all are included here in a more broadly circumscribed Tabernaemontaneae.

Of the tribes of the Rauvolfioideae recognized by Pichon $(1949,1950 \mathrm{~b})$ that have a dry inner pericarp, the "Alstonieae" (= Plumerieae sensu Leeuwenberg, 1994) appears to be the most heterogeneous (Endress et al., 1996; Sennblad \& Bremer, 1996; Sennblad, 1997). It is characterized by a plesiomorphic flower and fruit morphology, but several taxa have never been thoroughly studied. Preliminary molecular results indicate that winged seeds probably have arisen in parallel a number of times (Endress et al., 1996; Sennblad \& Bremer, 1996; Potgieter, 1999). Here, the traditional "Plumerieae" (sensu Leeuwenberg, 1994) are split into three tribes. The "Plumeriinae," the "Cerbereae" (= the "Cerberoideae" sensu Pichon, 1948 b), and the "Allamandeae" are combined to form the new Plumerieae. This is in accordance with independent studies, which suggest that the "Plumeriinae" is more closely related to the "Cerbereae" and the "Allamandeae" than to the remainder of the "Plumerieae" (Coppen \& Cobb, 1983; Fallen, 1985; Nilsson, 1986, 1990; Endress et al., 1996; Sennblad \& Bremer, 1996; Sennblad, 1997; Civeyrel et al., 1998). The "Craspidosperminae" (excluding Strempeliopsis and Plectaneia) is here combined with Melodinus as the new Melodineae. Delimitation of this tribe is somewhat imprecise. There is no single autapomorphic character known to be constant for all taxa. Rather, for the time being, circumscription must be based on a suite of characters and tendencies. These tendencies include: corolline corona often present, anthers sometimes with conspicuous sterile apical (sometimes also basal) appendages, ovary often syncarpous to varying degrees, and pollen sometimes porate and sometimes in tetrads. The "Alstoniinae" and most genera of the "Aspidosperminae" are combined to form the new Alstonieae. Like the Melodineae, the Alstonieae is plesiomorphic and diverse. Common traits found in this tribe are alternate or whorled leaves, conspicuous gaps in the corolla tube above the level of stamen insertion, and the lack of a corolline corona. Finally, the "Catharanthinae" is transferred from the "Plumerieae" to a newly defined Vinceae, based on seed morphology (Endress, unpubl. data) and DNA results (Sennblad \& Bremer, 1996; Sennblad, 1997). 
A source of confusion is the gaps in the corolla tube mentioned above as often present in the Alstonieae. The first report of these gaps was by Woodson (1951: 124-125), who used them as a criterion to separate Aspidosperma (in which he found them to be present) from other genera, such as Microplumeria, Geissospermum and Diplorhynchus, in which he found them to be "quite absent." Markgraf (1974: 105-106) described similar gaps in the Madagascan endemic Stephanostegia and raised the question of whether this was an indication of close relationship. Leeuwenberg (1997: 96), inexplicably, used this character in a key to separate Stephanostegia (gaps present) from Aspidosperma (gaps absent). The gaps are due to the incomplete fusion of the petal primordia above the stamens (Boke, 1948; Nishino, 1982; Sennblad et al., 1998: 1147). The resulting gaps are especially long and thus conspicuous in Aspidosperma and Stephanostegia. However, they are also present, though shorter and not easily visible except in serial section, in a number of other taxa, including Craspidospermum, Geissospermum, Haplophyton, Pleiocarpa and Picralima.

The "Rauvolfieae" of Pichon (1949) (= "Alyxieae" sensu Leeuwenberg, 1994) has traditionally been characterized by having drupaceous fruits with a stony endocarp. Here the tribe is divided into the Vinceae-which normally have a style head that is vertically differentiated into functional zones (Fallen, 1986), fleshy mesocarp, nonruminate endosperm, flat seeds without a deep hilar furrow, and colporate pollen-and the Alyxieae-which typically have a style head that is uniformly receptive and secretory, stringy or woody mesocarp, ruminate endosperm, cylindrical seeds with a deep hilar furrow, and porate pollen. Although the Vinceae and the Alyxieae are superficially similar, taxa of the Vinceae cluster toward the basal part of the family, and it shows some affinities to the Tabernaemontaneae, whereas the Alyxieae appears to be closer to the Plumerieae and Carisseae.

The second subfamily, the Apocynoideae, has generally been considered to be more homogeneous than the Rauvolfioideae, and tribal delimitation is correspondingly more difficult (Fallen, 1986; Leeuwenberg, 1994). The most significant contribution to classification of the Apocynoideae was made by Pichon (1950a), who recognized four tribes: "Parsonsieae," "Nerieae," "Ecdysanthereae," and "Ichnocarpeae." These tribes were based mainly on the manner in which the anthers were united with the style head, a character Pichon (1948c) termed the "retinacle." Because the retinacle is very delicate and is easily ruptured during dissection, characters based on its detailed structure have not been used by most subsequent apocynologists.

A number of revisions of Old World genera have been published by the Apocynaceae study group in Wageningen, under the leadership of A. J. M. Leeuwenberg (for references, see the literature cited in Leeuwenberg, 1983, 1988; Sennblad et al., 1998), and by Middleton (1994, 1995, 1997a, 1997b, and references therein). A detailed study by Endress et al. (1990) of the Holarrheninae (included in the "Plumerioideae" = Rauvolfioideae by Pichon, 1950b; De Kruif, 1981; and Leeuwenberg, 1983) resulted in the transfer of the three constituent genera (Holarrhena, Carruthersia, and Spirolobium) to the Nerieae (sensu Leeuwenberg, $1988=$ Wrightieae sensu Leeuwenberg, 1994) of the Apocynoideae. In the classification presented here all three genera are included in the Malouetieae. But broad, comparative studies of the group are lacking. In particular, the relationship of the Old World taxa with those in the New World has not been satisfactorily investigated, and this would be a rewarding focus for future studies of this subfamily.

In his most recent classification Leeuwenberg (1994) stated, "The Apocynoideae genera are so closely interrelated, that it is probably impossible to place them into distinct tribes or subtribes." Nonetheless, in the same publication, he recognized three tribes: Echiteae, Wrightieae, and Apocyneae. Leeuwenberg's Echiteae and Wrightieae correspond for the 
most part to Pichon's "Parsonsieae" and "Nerieae," respectively; his Apocyneae is an amalgamation of Pichon's "Ecdysanthereae" and "Ichnocarpeae."

Fortunately, interest in the Apocynoideae has revived in conjunction with the increasing use of molecular techniques. In a recent study of the Wrightieae, the three tribes of the Apocynoideae recognized by Leeuwenberg (1994) were all shown to be paraphyletic, whereas the retinacle proved to be a useful character (Sennblad et al., 1998). In the present classification, five tribes are recognized in the Apocynoideae: Wrightieae, Malouetieae, Apocyneae, Echiteae, and Mesechiteae; these are based mainly on retinacle structure and preliminary DNA results and are augmented by other characters, as indicated in the key. The composition of the tribes differs significantly from those of both Pichon (1950a) and Leeuwenberg (1994). For example, genera that were previously included in the Echiteae by Leeuwenberg (1994) are here dispersed among three tribes. The relocations are, thus, too numerous to be discussed individually. The five tribes of the Apocynoideae recognized here almost certainly represent a simplified scheme. The Apocyneae, especially, will probably need to be divided in some way, and some rearrangement of taxa will no doubt be necessary as more data accumulate. Nonetheless, until more adequate sampling is available for detailed studies, we feel this is the best representation.

\section{B. RECOGNITION OF THE FAMILY PERIPLOCACEAE}

After it was split from the Apocynaceae, the Asclepiadaceae was further divided into two families, the Asclepiadaceae and the Periplocaceae, on the suggestion of Schlechter (1905). This division was founded on the belief that in the Periplocaceae the pollen tetrads are loosely deposited on scooplike translators attached to a soft, sticky, somewhat amorphous viscidium, whereas in the remainder of the Asclepiadaceae the pollen is gathered into pollinia and attached to a cliplike corpuscle. The use of these two characters to separate these families was favored particularly by Bullock (1956), was supported by Hutchinson (1973) and Huber (1973), and has persisted to the present (see, for example, Kunze, 1993, 1996; Swarupanandan et al., 1996; Omlor, 1998). However, as the genera of the Periplocoideae have become better known, evidence has emerged that in many of them the pollen is gathered into pollinia (Verhoeven \& Venter, 1998). We have personally seen this in Decalepis, Gymnanthera, and Hemidesmus. In addition, in Decalepis the two pollinia produced in each locule of the anther tend to be pressed quite closely together, so that the appearance of a single pollinium-and hence only two on each translator-is created. This suggests the arrangement in the Asclepiadoideae, and the same pairing of pollinia has been observed in three genera of the Secamonoideae: Genianthus (Klackenberg, 1995b), Secamone (Civeyrel, 1994), and Secamonopsis (Civeyrel, 1996). In the Secamonoideae, the pollinia are similar to those seen in the Periplocoideae, in that an outer wall is wanting. Therefore, the statement of Kunze (1996: 576) that "the jump from sticky tetrads to well-defined pollinia could be considered to be quite large," which was used as a justification for separating the Periplocoideae and the Asclepiadoideae at the level of family, is unjustified. Thus, in reality, the Periplocoideae and the remainder of the Asclepiadaceae are separated not by the presence/absence of pollinia but by the presence of a soft, sticky, more or less amorphous viscidium versus the presence of a harder corpuscle.

It has also been said that the anthers are free from the style head in the Periplocoideae, whereas they are united to form a gynostegium in the Asclepiadaceae (Schumann, 1895; Meve \& Liede, 1994; Swarupanandan et al., 1996). In all taxa of the Periplocoideae we have investigated, the anthers are clearly postgenitally fused to the style head (and this is shown here in Figures 2-7). Therefore, this claim is entirely without foundation. We can only sur- 


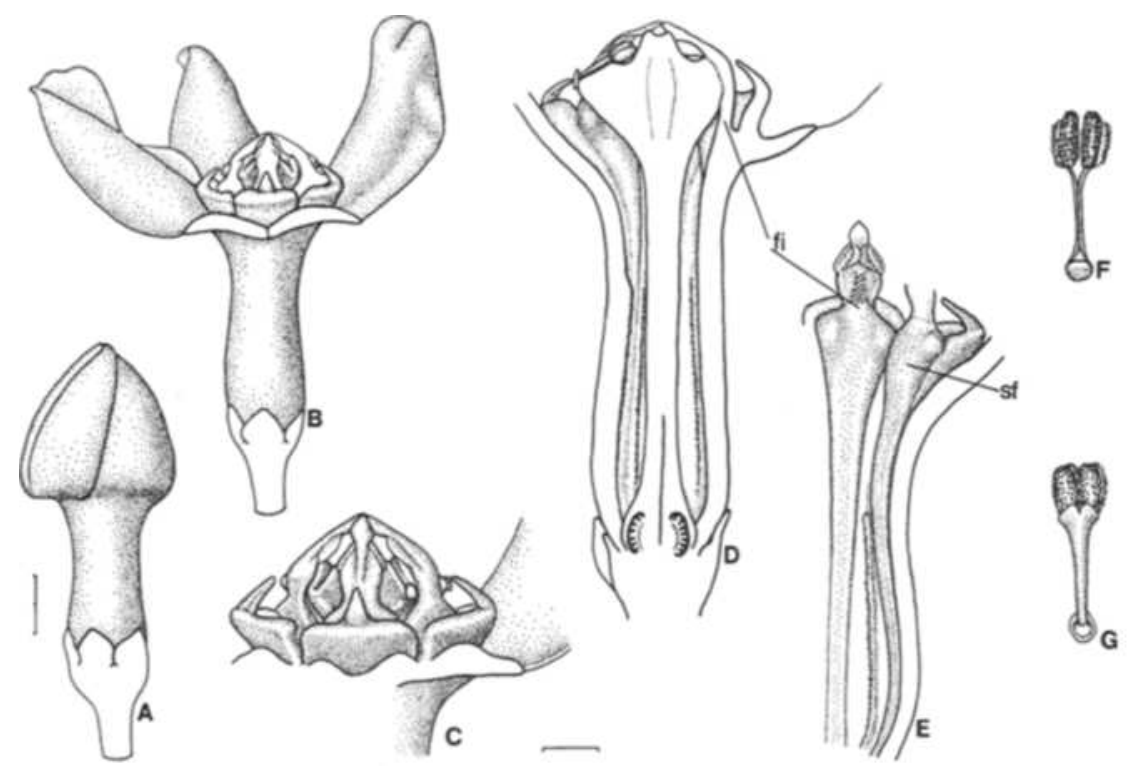

Fig. 2. Gymnanthera cunninghamii (P. I. Forster 6208): periplocoid with long corolla tube, staminal feet stretching down most of the tube but not thickening around neck of ovary. Pollen gathered into pollinia. A. Bud. B. Flower with two petals removed. C. Gynostegium. D. Half-flower. E. Style removed to show staminal feet running down tube and alternating lower down with ridges of fine hairs. F. Pollinarium from above. G. Pollinarium from rear. $f i=$ filament; $s f=$ staminal foot. Scales: A, B, $2 \mathrm{~mm}$ (at A); CE, $1 \mathrm{~mm}$ (at C); F, G, $0.5 \mathrm{~mm}$ (at F).

mise that the authors of these publications never actually looked closely at a periplocoid flower.

Another feature of the Periplocoideae is the lack of any lignified tissue in the margins of the anthers. The anthers are also not extended laterally toward the base into a swallow-tailed shape and therefore cannot form guide rails. This lack of guide rails is not matched in any other asclepiads except, to some extent, in Fockea: in Fockea the margins of the anthers are laterally closely adpressed to one another and are lignified toward the base, but they do not form a guide rail. This character is therefore somewhat equivocal for separating the Periplocoideae from the Asclepiadaceae.

A staunch proponent of recognizing the Periplocaceae as a separate family is Kunze $(1990,1996)$. Much of his reasoning is based on his interpretation of the differences in the bases of the stamens between the Periplocoideae and the Asclepiadoideae. For the Periplocoideae he described the swollen region below the filaments as the "basal tube" and interpreted it as corolline or receptacular (Kunze 1990:38). For the Asclepiadoideae he concluded that "the border between a receptacular base of the staminal column and an upper part in which the filaments are fused cannot be made out. In consequence the tubular part situated below the nectaries is interpreted [as] receptacular in the whole family" (p. 44).

In his later paper Kunze (1996: 567) stated that the filament tube in the Asclepiadoideae has evolved by "replacement of the original free filaments by new elements originating from the inward[ly] protruding base[s] of the filaments." He stated as well that these results refute 


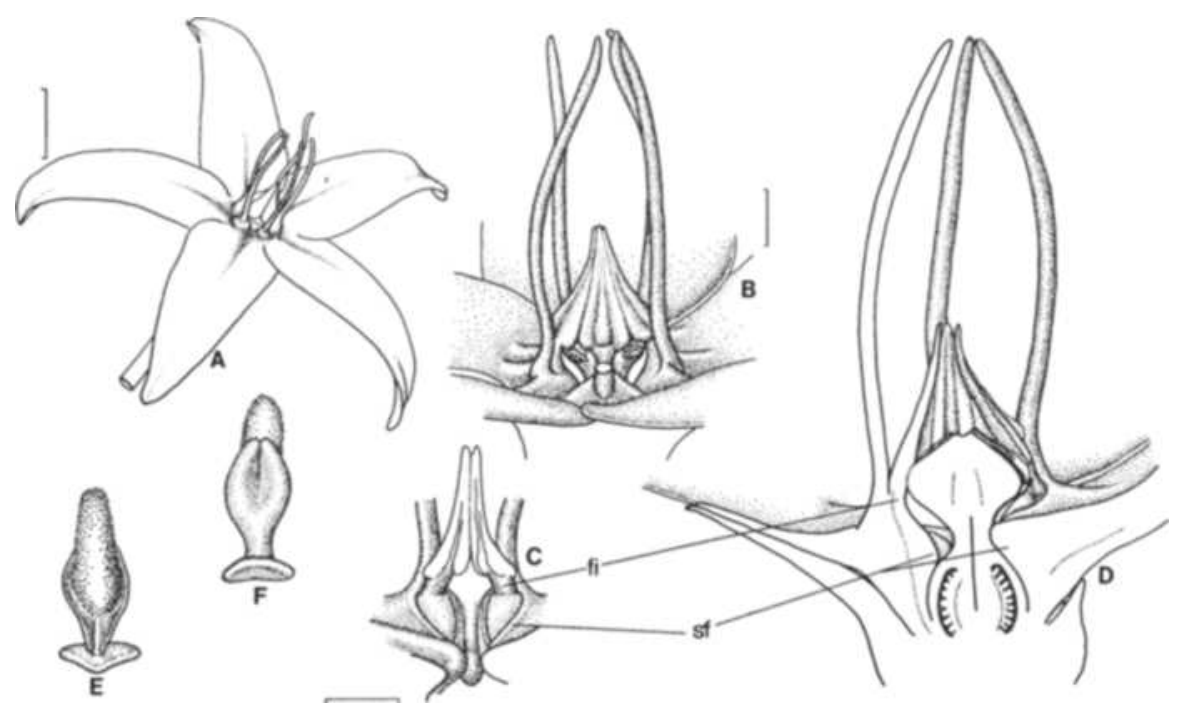

Fig. 3. Ischnolepis tuberosa (P. V. Bruyns 5963): periplocoid with more or less flat flower and corona reduced to single lobes, staminal feet conspicuous but not forming tube around style. A. Flower. B. Gynostegium. C. Two anthers, viewed from inside, with staminal feet encircling their swollen bases. D. Half-flower. E. Pollinarium from above. F. Pollinarium from rear. $\mathrm{fi}=$ filament; $\mathrm{sf}=$ staminal foot. Scales: A, 4 mm; B, $1 \mathrm{~mm}$; C, D, $1 \mathrm{~mm}$ (at C); E, F, $0.5 \mathrm{~mm}$ (at C).
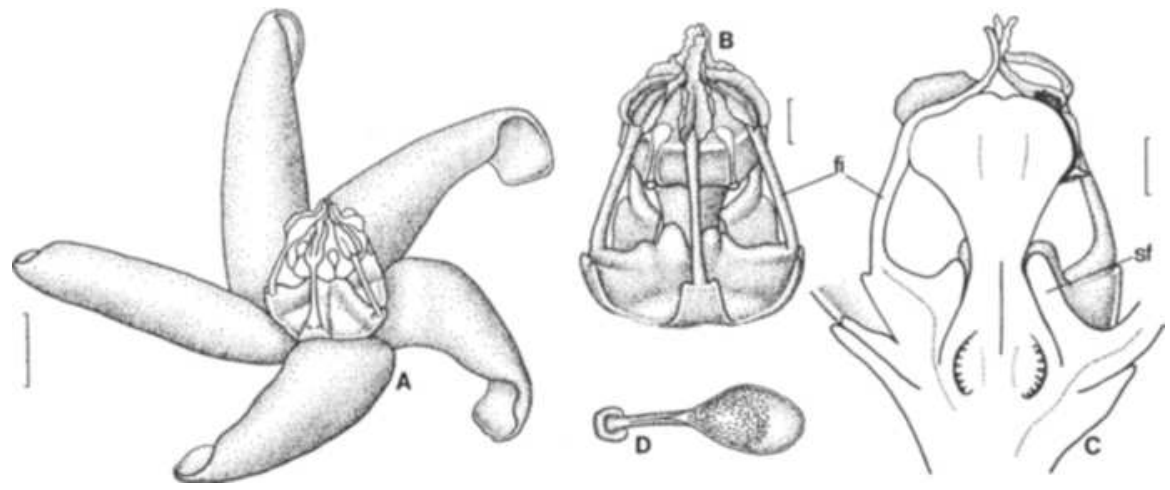

Fig. 4. Cryptolepis grayi ( $P$. Endress 9136): periplocoid with short corolla-tube, relatively long style, very long filaments arising on short staminal foot, which forms a significant tube around the base of the style. A. Flower. B. Gynostegium. C. Half-flower. D. Pollinarium. fi $=$ filament; $s f=s t a m i n a l$ foot. The staminal foot here begins to form a tube very similar to that in, e.g., Fig. 7E. Scales: A, $3 \mathrm{~mm}$; B, $1 \mathrm{~mm}$; C, $1 \mathrm{~mm} ; \mathrm{D}, 0.5 \mathrm{~mm}$ (at A). 

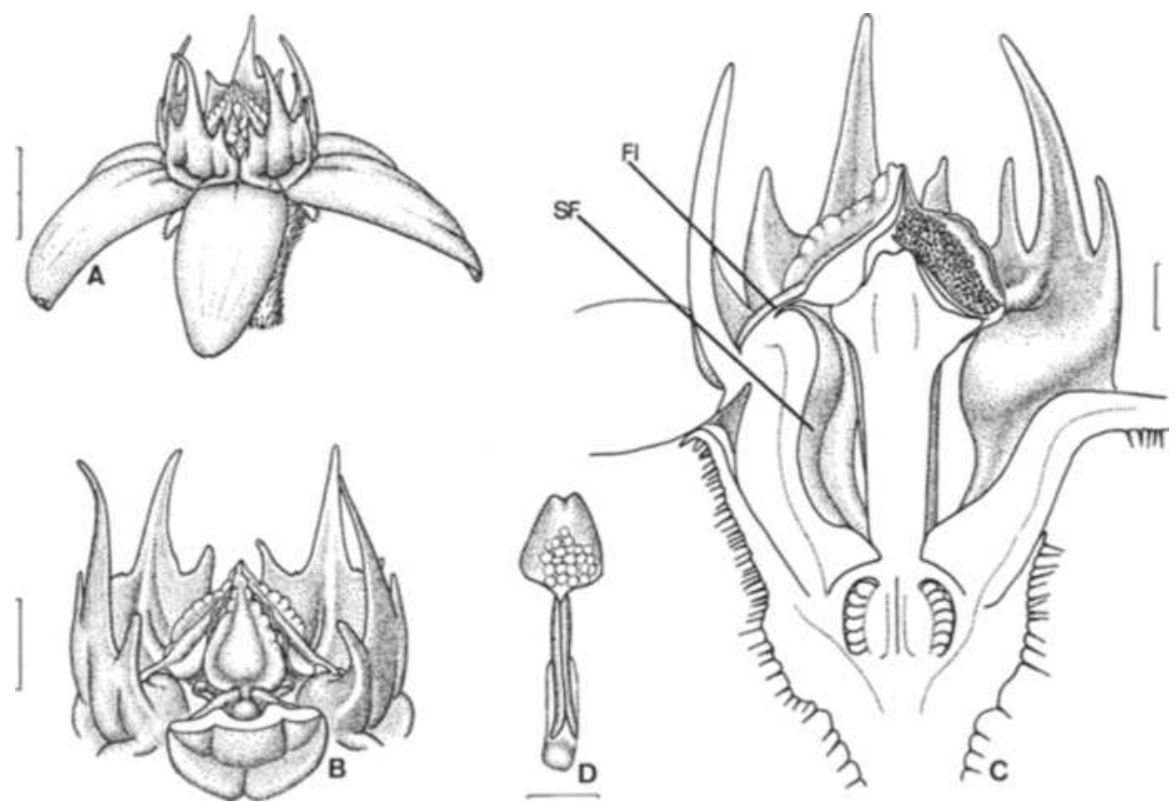

Fig. 5. Raphionacme procumbens (P. V. Bruyns 4444): periplocoid with shorter corolla-tube, staminal feet beginning to enclose top of ovary. A. Flower. B. Gynostegium with one corona lobe cut away. C. Half-flower. D. Pollinarium. FI = filament; SF = staminal foot. Scales: A, $2 \mathrm{~mm} ; \mathrm{B}, 1 \mathrm{~mm} ; \mathrm{C}, 0.5 \mathrm{~mm}$; $\mathrm{D}, 0.25 \mathrm{~mm}$.

his hypothesis that the basal part of the "asclepiad filament tube is of receptacular origin" and that, consequently, the "basal tube in the Periplocaceae and the [basal part of the] filamenttube in the Asclepiadaceae are not homologous" (p. 573). This provided him with an additional reason for recognizing the Periplocoideae as a separate family.

In the Periplocoideae the stamens each have a small, more or less cylindrical filament beneath the anther. These filaments are inserted at different heights on the corolla tube but always arise on the apex of a thickened ridge (which sometimes appears to be wrapped around the base of the filament and is usually deeply grooved below the filament). We shall term this ridge the "staminal foot," although we have found that, at the base of the stamen, it is impossible to differentiate clearly between tissues derived from the stamen and those that are corolline in origin. Nectar is secreted on the sides of this staminal foot, and in some cases the area between adjacent feet is also nectariferous. We have followed the development of this staminal foot, together with the length of the corolla tube, through several taxa in the Periplocoideae and have observed the following.

First, in species with a relatively long corolla tube, this staminal foot runs down the tube from the anthers and may fade out before the base (e.g., Gymnanthera [Fig. 2]; Raphionacme monteiroae, $R$. namibiana). It therefore does not necessarily have anything to do with the lowermost part of the tube and need not form any kind of "basal tube."

Second, in many periplocoids the corolla tube is much shorter, and in some the corolla is nearly flat (Ischnolepis [Fig. 3]). In cases where the corolla tube is shorter, the bases of these feet may become swollen around the neck of the style above the ovaries, initially just above 

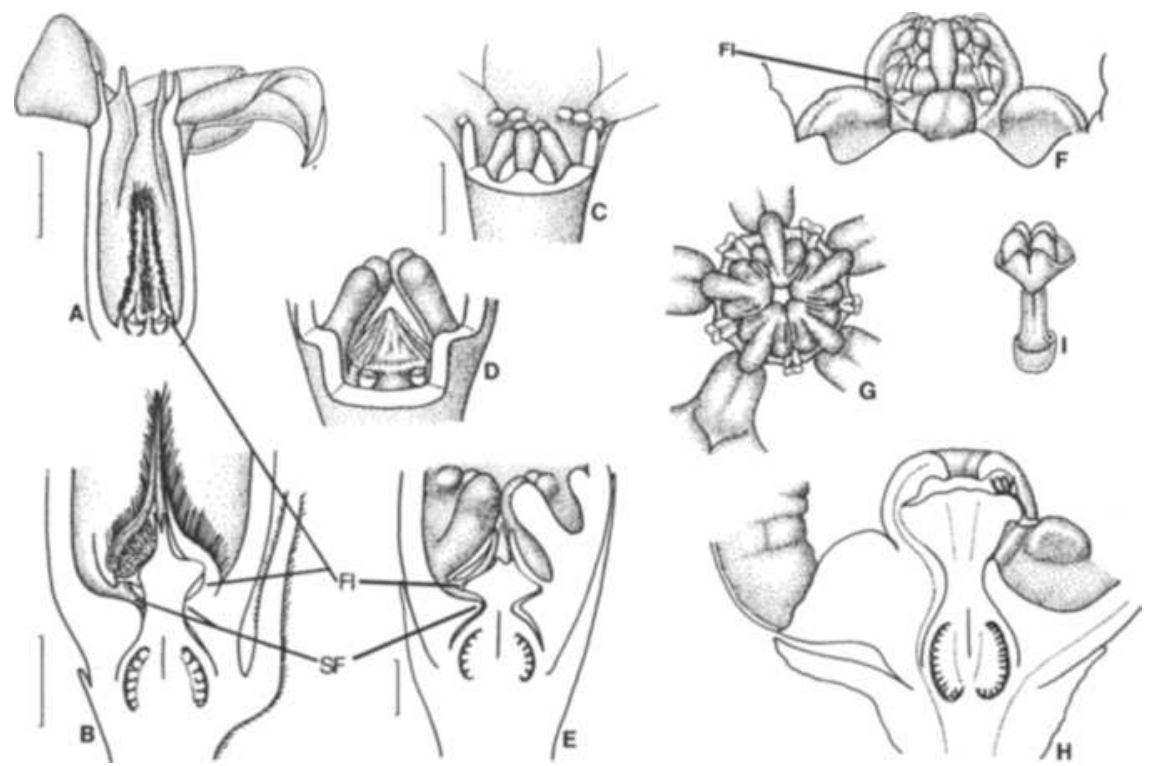

Fig. 6. Periplocoideae: the formation of the staminal tube from the staminal foot. Ectadium virgatum (P. V. Bruyns): periplocoid with separation of corolline corona at base of petals and staminal foot bearing the filaments, feet beginning to form staminal tube but still discrete. A. Dissected flower with two petals removed. B. Half-flower showing base of tube. Cryptolepis oblongifolia ( $P, V$. Bruyns): periplocoid with separation of corolline corona at base of petals and staminal foot with filaments with conspicuous corona lobes at apex of each foot. C. Dissected flower with two petals removed. D. Further dissected flower with one corona-lobe removed, showing anthers. E. Half-flower. Hemidesmus indicus (P. V. Bruyns): periplocoid with staminal feet right up against style, completely enclosing it and ovaries and forming staminal tube; anthers fused to underside of style-head. F. Gynostegium from side. G. Gynostegium from above. H. Half-flower. I. Pollinarium. FI = filament; SF = staminal foot. Scales: A, $2 \mathrm{~mm} ; \mathrm{B}, 1 \mathrm{~mm} ; \mathrm{C}, 1$ $\mathrm{mm} ; \mathrm{D}-\mathrm{H}, 0.5 \mathrm{~mm}$ (at E); I, $0.25 \mathrm{~mm}$ (at C).

the ovary (Cryptolepis grayi [Fig. 4]; Raphionacme procumbens [Fig. 5]; Stomatostemma monteiroae [Fig. 6]); then, with shorter style, they form a ring around the top of the ovary and gradually fill up the space between the ovary and the style head (Cryptolepis oblongifolia, Ectadium [Fig. 6]). The swollen bases that make up this ring are usually incompletely fused, so that the ring is undulate, with five mounds alternating with five slits (or at least epidermal surfaces) between them.

Third, in extreme cases the limb of the foot disappears, and the filaments and anthers are pushed up against the style head. The lateral zone between adjacent feet fuses into a continuous ring around the style beneath the style head. Here all traces of epidermis between the swollen bases of the feet have disappeared, and a "staminal tube" around the style has arisen (Hemidesmus indicus [Fig. 6]).

In our view, this arrangement leads directly to that found in the Secamonoideae/Asclepiadoideae, where the staminal tube has evolved further (Fig. 7D-G). In the Secamonoideae/Asclepiadoideae the anthers sit directly atop somewhat rectangular "filaments" (see Kunze, 1990: figs. 136-140; 1996: figs. 67-75). The partly to wholly fused inner, lateral margins of these "filaments" form the so-called filament tube around the ovaries and style. These 

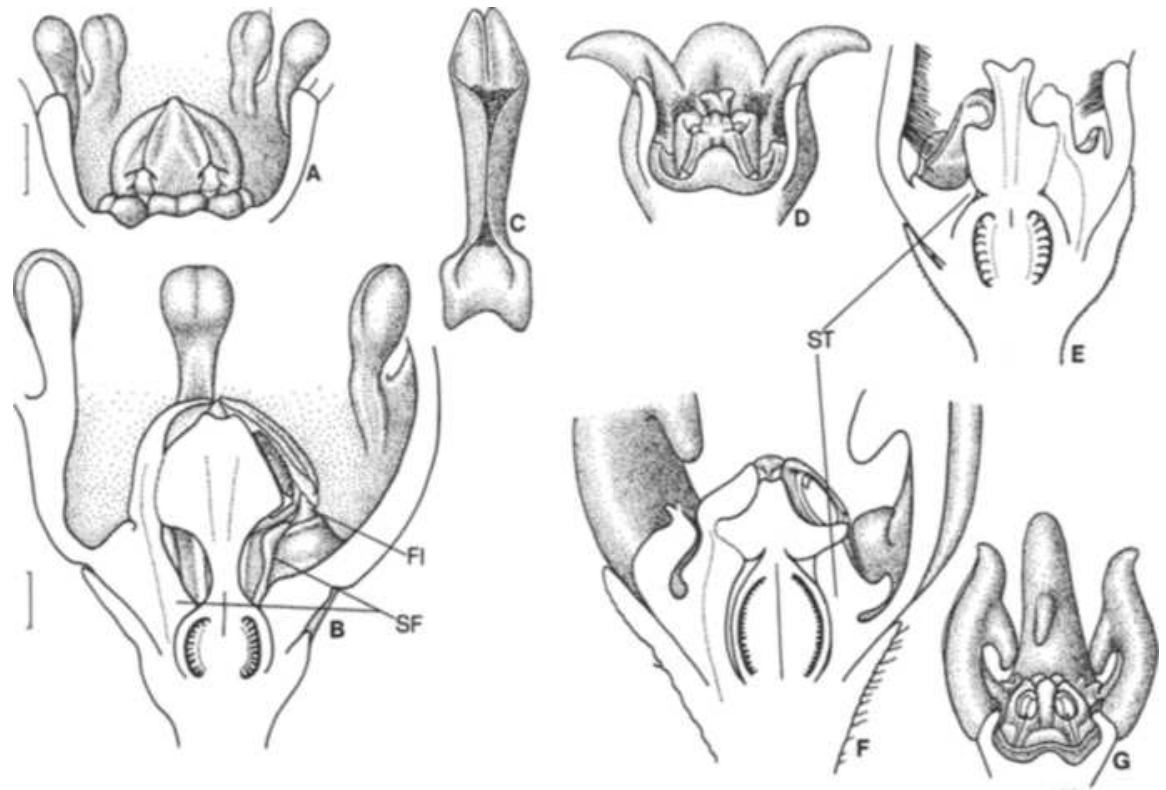

Fig. 7. Periplocoideae, Secamonoideae and Asclepiadoideae: staminal feet with filament, staminal tube without filament. Stomatostemma monteiroae ( $P . V$. Bruyns): periplocoid with staminal feet near base of tube, corolline corona left behind at base of petals, ovary only partly enclosed by base of feet. A. Base of corolla tube with two petals removed. B. Half-flower. C. Pollinarium. Secamonopsis madagascariensis ( $P . V$. Bruyns): secamonoid with staminal tube on which anthers are sessile; outer corona encircling entire gynostegium. D. Dissected flower with two petals removed. E. Half-flower. Leptadenia reticulata $(P . V$. Bruyns): asclepiadoid with staminal tube on which anthers are sessile; flowers with corolline corona and outer corona encircling gynostegium. F. Half-flower. G. Dissected flower with two petals removed. $\mathrm{FI}=$ filament; $\mathrm{SF}=$ staminal foot; $\mathrm{ST}=$ staminal tube. Scales: $\mathrm{A}, 2 \mathrm{~mm} ; \mathrm{B}, \mathrm{G}, 1 \mathrm{~mm}$ (at B); D, F, $0.5 \mathrm{~mm}$ (at B); C, E, $0.5 \mathrm{~mm}$ (at A).

filaments have a very unusual shape in comparison to those in the Periplocoideae (and the rest of the Apocynaceae). In view of the development of the staminal tube in som^ Periplocoideae and the nature of the filaments in this group, we find it altogether more plausible that in the Secamonoideae/Asclepiadoideae the filament has been lost entirely and the so-called filament and filament tube are really a further development of the "staminal tube" that has appeared already in some Periplocoideae. We therefore postulate that the Secamonoideae/Asclepiadoideae (Fig. 7) form a fourth stage in the cline outlined just above, namely:

Fourth, the staminal feet are attached to the corolla now only at a narrow base, and adjacent feet are fused into a continuous ring around the style below the style head; that is, all traces of epidermis between their swollen bases have vanished, and they form a "staminal tube." The small, cylindrical filament is lost, and the anthers are consequently sessile on this staminal tube.

Another important fact is that while the situation described in the third stage leads naturally (in our view) to that in the Asclepiadoideae, the arrangement in first stage is similar to that in various Rauvolfioideae and Apocynoideae (cf. Fig. 8). In most Rauvolfioideae and 

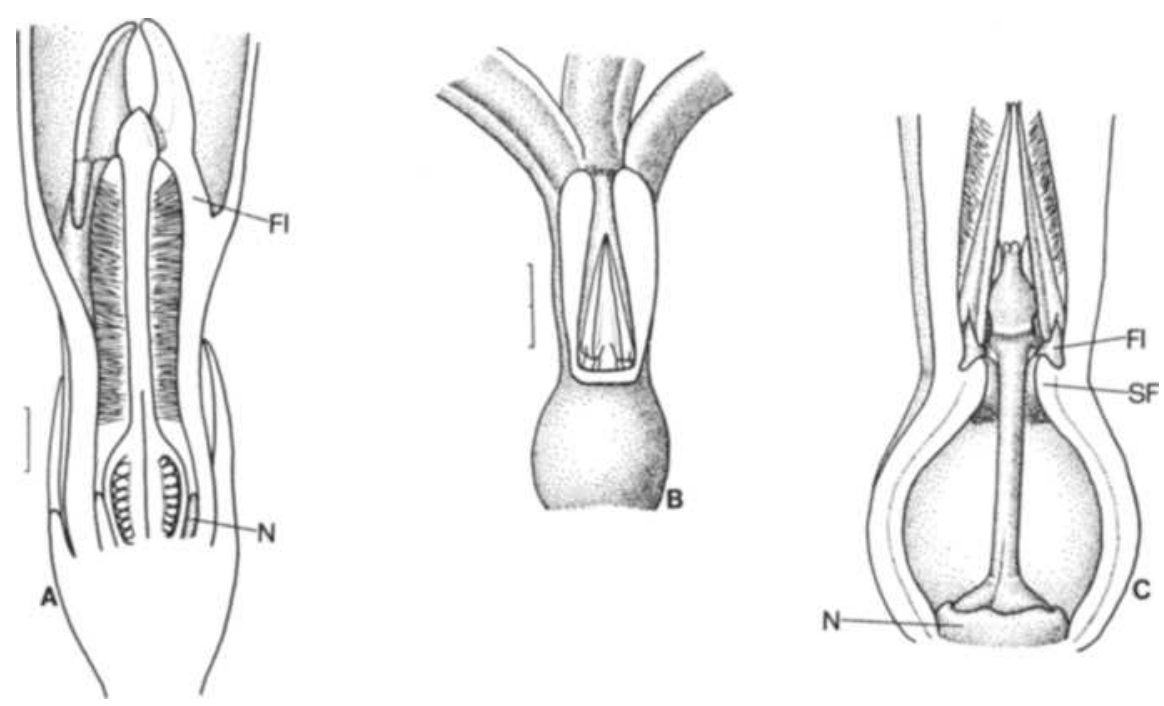

Fig. 8. Apocynoideae with filaments fused to wall of corolla tube, with corolla tube thickened beneath them. A. Half-flower of young bud of Pachypodium succulentum (cultivated material). B-C. Aganosma marginata (Fairchild Tropical Gardens). B. Part of flower with two petals excised and upper part of tube opened to expose anthers. C. Lower part of tube opened to show staminal feet and annular nectary around ovaries. In $\mathrm{C}$ a distinct staminal foot is present beneath the filament. $\mathrm{FI}=$ filament; $\mathrm{N}=$ nectary; $\mathrm{SF}=$ staminal foot. Scales: $\mathrm{A}, 1 \mathrm{~mm} ; \mathrm{b}, 2 \mathrm{~mm} ; \mathrm{C}, 1 \mathrm{~mm}$ (at $\mathrm{B})$.

Apocynoideae there is also a small, more or less cylindrical filament beneath the anther. Moreover, there are also often ridges running down beneath each anther toward the base of the corolla tube (e.g., many Tabernaemontaneae, Apocynoideae).

Further aspects lend support to the existence of a cline from the Periplocoideae to the Asclepiadoideae. One is the position of the retinacle: When the filament is present, it lifts the anther above the thickest portion of the style head, so that the five anthers are connivent above it and are fused to the style head above its thickest portion (e.g., Fig. 4C and, especially, Fig. 5C). In Hemidesmus, where the filament is particularly short, the anther is fused to the style head just beneath its thickest portion (Fig. 6H). This is typically the arrangement in the Asclepiadoideae.

The second aspect is the corona. Kunze (1990) has also further differentiated between the Periplocaceae and the Apocynaceae on one hand and the Asclepiadaceae on the other by his conclusion that "the staminal corona in Asclepiadaceae is not homologous to the corona in Periplocaceae and Apocynaceae" (1990: 45). The "corona lobe" in Raphionacme procumbens (see Fig. 5) clearly consists of three parts: a robust central lobule immediately behind the base of the filament inserted on the apex of the staminal foot, and two rather smaller lobules lateral to the central one. Kunze (1990) demonstrated clearly that these emergences are of corolline origin. However, in our view, a more important aspect is the fact that the robust, central lobule appears to be more intimately connected with the swollen staminal foot than the other two lobules and is more flexible in its position on the corolla tube than are the others.

In several other cases that we have examined (Decalepis, Cryptolepis, Ectadium, Stomatostemma [Figs. 6-7]), the apex of the staminal foot is some distance below the base of the petals. In Ectadium and Stomatostemma the corona has been left at the base of the petals, it is 
obscurely bifid (or bifid in its early stages), and there is no corona at the apex of the foot; in Cryptolepis this robust lobule arises more or less in the middle of the tube at the apex of the foot but some distance below the small pairs of corolline corona lobules. In Decalepis the robust lobule is again a little away from the base of the petals, but here no lobules are left at the base of the petals. This situation again bears considerable similarity to many coronas found in the Asclepiadoideae.

The third aspect is the nectaries. In the Periplocoideae the nectaries are located on the sides of the staminal foot and/or in troughs between them; at any rate, below the filament. In the Asclepiadoideae the primary nectaries are located behind the guide rail at the top of the socalled filament tube and above the filaments. If this purported "filament tube" has evolved from the same staminal feet of the Periplocoideae, this would explain the presence of nectaries between the bases of the anthers and would remove the need to assume that nectaries have moved from below the filaments in the Periplocoideae to above them in the Asclepiadoideae.

Taking the above data into consideration, we fird (as suggested informally by Bruyns [1994]) that there is little morphological support for the separation of the Periplocoideae from the remainder of the asclepiads at the level of family.

Relatively little systematic work has been done on the Periplocoideae. Taxonomic revisions and pollen studies for a number of African genera have been published by Venter and Verhoeven (e.g., Verhoeven \& Venter, 1988; Venter \& Verhoeven, 1993, 1994; and references therein). In addition, four Malagasy genera were revised by Klackenberg (1997b, 1998 , 1999). However, the Asian taxa remain especially poorly known.

Venter and Verhoeven (1997) published a much-needed comparative study of the Periplocoideae, and for the first time tribes were delimited for the subfamily, based mainly on floral characters. Numerous superfluous genera were reduced to synonymy, and they recognized 44 genera (for a total of about 160 species), of which 17 are monotypic and a further 10 have just two species. We have incorporated into our classification the generic synonymy that Venter and Verhoeven propose.

However, for two reasons, we have not incorporated their tribes. First, although we are familiar with relatively few of the species involved, those that do we know do not fit well into this classification. For example, in Decalepis nervosa the corolla tube is so short that the flower is more or less flat; in Camptocarpus linearis the same is true. Yet both belong to genera in the Gymnanthereae, where the corolla tube is "well-defined and broadly campanulate to cylindrical" (Venter \& Verhoeven, 1997: 710). In addition, the flowers of Ischnolepis tuberosa are almost completely flat (Fig. 3), and we have been able to find almost no differences between them and flowers of Petopentia natalensis. Yet these two monotypic genera are placed in different tribes. Klackenberg (1999) also found that species of Petopentia fall into three different tribes using the tribal classification of Venter and Verhoeven (1997) and thus doubted its value. Second, they conflict with the molecular results of Civeyrel (1996). There still seem to us to be far too many small genera. However, until detailed treatments of most of these taxa are available, it seems unlikely that any satisfactory subdivision of the subfamily can be achieved.

\section{INFRAFAMILIAL CLASSIFICATION OF THE ASCLEPIADACEAE S.STR.}

\section{Recognition of the Secamonoideae}

When Robert Brown (1810a, 1810b) separated the Asclepiadaceae from the Apocynaceae, he recognized three groups within the former: the "Asclepiadeae verae" (= Asclepiadoideae), the Periploceae, and an unnamed third group that contained only Secamone. Because it 
was unnamed, the status of this third group was ambiguous, and it was therefore subsumed in the Cynanchoideae (= Asclepiadoideae) in subsequent classifications by some authors (Bentham, 1876; Schumann, 1895). More commonly, however, it has been given equal rank (Endlicher, 1838; Decaisne, 1844; Safwat, 1962; Bruyns \& Forster, 1991; Liede \& Albers, 1994). The Secamonoideae is a rather poorly known group. Nearly 80 species belong to Secamone (Goyder, 1992; Klackenberg, 1992a, 1992b), and there are at least 60 species in Toxocarpus and 16 in Genianthus (Klackenberg, 1995b). There are also a few small genera (Klackenberg, 1995a, 1997a; Civeyrel, 1996).

Morphologically, the Secamonoideae fall somewhere between the Periplocoideae and the Asclepiadoideae and share characters with both of these subfamilies. Although the flowers may occasionally be large (up to $100 \mathrm{~mm}$ in diameter in Calyptranthera grandiflora), they are mostly very small, and the constituent parts are similarly tiny. This applies especially to the minute pollinaria. As in the Asclepiadoideae, the pollinarium consists of a corpuscle and pollinia. The corpuscle in Pervillea, Secamone, and Secamonopsis arises as a single body that is U-shaped in cross section and grows vertically above the secretory fields. When fully developed it is yellowish and somewhat waxy and soft (Omlor, 1996). This contrasts strongly with that in the higher asclepiads, where the corpuscle develops from two distinct parts, which later become fused across the base as the secretory fields themselves increase in size. In the higher asclepiads the corpuscle also has a rigid and much harder consistency.

Although the pollinia were traditionally considered to be attached directly to the corpuscle in the Secamonoideae, recent studies in Secamone (Civeyrel, 1995, 1996) have shown that in several cases there is a short caudicle between the pollinia and the corpuscle. Because the main distinction between Secamone and Secamonopsis was the absence/presence of a caudicle, this brings the distinctness of these genera somewhat into question.

Furthermore, in the Secamonoideae each anther has four locules and consequently produces four pollinia (as in the genera of the Periplocoideae that bear pollinia and unlike the Asclepiadoideae, in which each anther has only two locules). Civeyrel $(1995,1996)$ has made a number of interesting observations in the Secamonoideae, two of which suggest independent trends toward reduction from four to two pollinia per pollinarium. In the first trend the pollinia produced by one flank of an anther are closely adpressed to one another (as noted above for some Periplocoideae as well), thereby giving the impression that each anther produces only one pollinium on either side and that each corpuscle thus has only two pollinia attached to it. In the second trend, observed in Secamone, Secamonopsis, and Trichosandra, one of the pollinia produced in each locule is much smaller than the other and is much more loosely attached to the corpuscle. In these cases, each pollinarium contains only two functionally efficient pollinia, which is reminiscent of the situation in the Asclepiadoideae. However, in the Secamonoideae with functionally bisporangiate anthers, it is the two inner (ventral) ones that are reduced (Civeyrel, 1995, 1996), whereas in the Asclepiadoideae it is the two outer (dorsal) ones that have become obsolete.

A more detailed inspection of the pollinia of the Secamonoideae shows that they differ from those in the Asclepiadoideae in that they are composed of tetrads held together by crosswall fusion, without an outer wall enclosing the pollinium. This is most similar to those genera of Periplocoideae with pollinia (Civeyrel, 1996; Verhoeven \& Venter, 1998). It differs from the Asclepiadoideae, in which, in all members investigated to date, with the exception of Fockea (R. Verhoeven, pers. comm.), the pollinium comprises individual pollen grains and the whole structure is covered by a thick wall (the ectexine of Schill \& Jäckel, 1978; Dannenbaum \& Schill, 1991). Schill and Jäckel (1978) reported a thin outer wall enclosing the pollinium in Secamone ligustrifolia, but the composition of this wall was not studied in detail. Thus 
it is uncertain whether it is composed of sporopollenin, like those in the Asclepiadoideae, or of elastoviscin, which Dannenbaum and Schill (1991) found covering the tetrads in Raphionacme (Periplocoideae).

From the short discussion above, it is clear that the Secamonoideae are distinct from both the Periplocoideae and the Asclepiadoideae and deserve subfamilial status. It is by far the smallest subfamily, with only nine genera, all of which are included here in the single tribe Secamoneae.

\section{Relationships within the Asclepiadoideae}

In the Asclepiadoideae, four tribes are usually recognized: Marsdenieae, Stapelieae (here as Ceropegieae), Asclepiadeae, and Gonolobeae. Efforts have been made to refine the definitions of the tribes, especially by Woodson (1941) for the American taxa, Kunze (1995) for the Gonolobeae, Liede (1997) for the Asclepiadeae, and Omlor (1998) for the Marsdenieae. In the case of the Ceropegieae, which is probably the best known of these tribes, the difficulties were discussed at length in Bruyns and Forster (1991) and will not be repeated here. A listing of tribes and genera, which is nearly complete, was provided by Liede and Albers (1994).

One new tribe, the Fockeeae, has recently been separated from the Marsdenieae (Kunze et al., 1994). The Fockeeae was separated from the Marsdenieae by the lack of caudicles and the lack of a floor in the lower third of the corpuscle. Caudicles are lacking mostly in Genianthus and Secamone but may sometimes be present (Civeyrel, 1994; Klackenberg, 1995b), so that this seems to be a poor character on which to base a tribe. In addition, very frail corpuscles, which easily split longitudinally, are known in Eustegia, Gongronema, and Tylophora. In these genera it is the floor of the corpuscle that is weak, even though it may be present for most of the length of the corpuscle. In Eustegia (Bruyns, 1999) it has the same V-shaped profile that Kunze (1993: 117) found in Fockea and observed as well in Tylophora. Thus this character, too, is not strong. Another character given by Kunze et al. (1994: 373), namely "stamens with large apical appendages," is true for Fockea but not for Cibirhiza, so it is certainly not definitive for the tribe.

A further argument that Kunze (1993) put forward to isolate Fockea from the remaining Asclepiadaceae was the hypothesis that the "lateral adhesive pads in Fockea" (attaching the corpuscle to the guide rails) are homologous to the "caudicles of other Asclepiadaceae" and therefore are unique to Fockea (and Cibirhiza). Kunze (1994: 232) has subsequently abandoned this hypothesis and replaced it with the view that they are nonhomologous, which seems rather more plausible to us as well. In addition, Kunze (1990: 42-44) found that the corona in Fockea developed somewhat differently from that in other asclepiads. The ontogeny of the corona of Cibirhiza was never investigated, but it was claimed (Kunze et al., 1994: 373) that the basic construction of the corona is similar in both genera. Our own investigations have not confirmed Kunze's original conclusions about the differences in the development of the corona in Fockea and other Asclepiadaceae, and we have found that they follow more or less the same pattern (Fig. 9A-H).

In most features Kunze $(1990,1996)$ has demonstrated that Fockea occupies an intermediate position between Secamone and the more advanced Asclepiadoideae. Similarly, it has pollinia made up of tetrads not covered by an outer envelope (i.e., resembling those in Secamonoideae and those Periplocoideae with pollinia, rather than other Asclepiadoideae $[R$. Verhoeven, pers. comm.]).

An intermediate position for Fockea is also suggested by cladistic analyses of both morphological and molecular data in a study by Civeyrel (1996). In this study Fockea appears iso- 

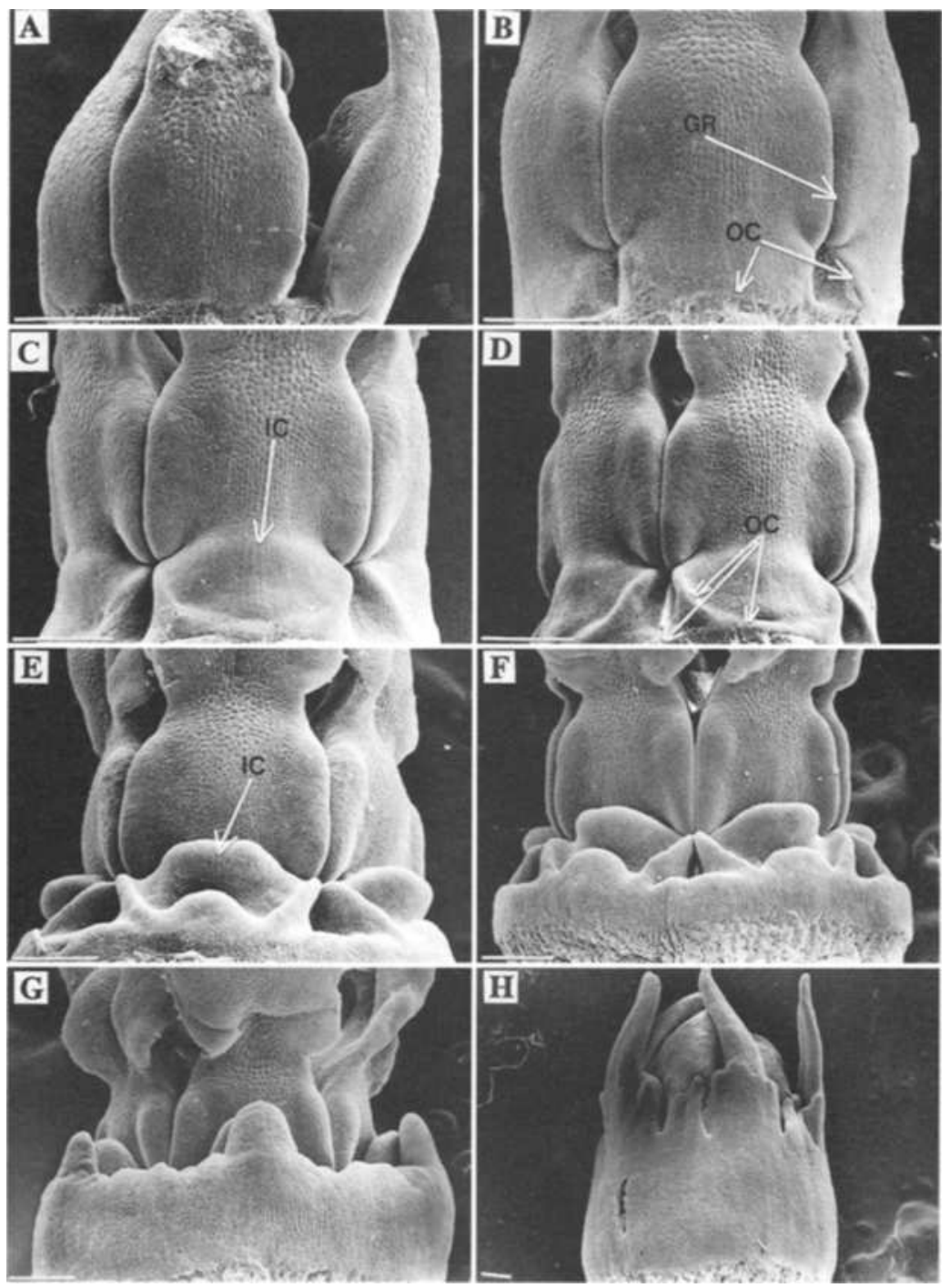

Fig. 9. Coronal ontogeny in Fockea capensis (ex hort. L. J. Hill). A. Very early stage with no corona present (one anther knocked back in preparation). B. Beneath guide rail (GR, arrowed) a small swelling has begun to appear, which forms a "bay" beneath each guide rail with vertically descending parts beneath each side of the rail and a floor well below the rail; also a swelling beneath the anther but somewhat below it. $\mathbf{C}$. The bay beneath the guide rail has increased greatly in size, and adjacent bays are connected by a low ridge; the inner corona (IC, arrowed) has begun to appear. D-F. Inner corona increases greatly in size; outer series differentiates into three different kinds of lobes: a broad one behind each inner lobe, two ascending ones rising up to touch the base of the guide-rail (derived from the vertically descending parts in B) and an enclosing lobe below the rail (arising from the floor well below the rail in B). G-H. Structures that were clear in $\mathrm{F}$ begin to be obscured once more: anthers begin to disappear inside the tube formed by the corona, which is about half its mature size. $\mathrm{GR}=$ guide rail; $\mathrm{IC}=$ inner corona; $\mathrm{OC}$ = outer corona. Scales: all $=200 \mu \mathrm{m}$. 
lated at the base of the Asclepiadoideae. This could be interpreted as support for the tribe Fockeeae. However, this seemingly isolated position could also be due to inadequate sampling, for only two other species from among the 570 or so species of the diverse tribe Marsdenieae were included. In order to assess accurately the Fockeeae it would be necessary to include more putatively basal Marsdenieae. The tribe Fockeeae is therefore abandoned, with Fockea and Cibirhiza placed once more in the Marsdenieae.

The most basal tribe of the Asclepiadoideae is the Marsdenieae. The Marsdenieae are mainly separated from the Ceropegieae by the absence of a hyaline insertion crest on the upper or outer edge of the pollinium (if present, it lies on the inner or lower edge of the pollinium), and the more or less complete absence of an outer corona (Bruyns \& Forster, 1991; Omlor, 1998). Together, the Marsdenieae and Ceropegieae are essentially separated from the Asclepiadeae by the orientation of the pollinia in the anthers: pendulous (below the corpuscle) in the Asclepiadeae; erect (above the corpuscle) in the Marsdenieae and Ceropegieae. The latter is considered to be the primitive condition (Kunze, 1993: 120). Other characters that can be useful in deciding whether a genus belongs to the Asclepiadeae rather than to the Marsdenieae or Ceropegieae are the presence of a narrow neck between the ovaries and the style head and of a constriction at the base of the sterile apical appendage of the anther, usually located opposite the corpuscles.

However, these characters do not exclusively separate these tribes. Some Ceropegieae (e.g., Orbea and Macropetalum) also possess a narrow neck between the ovaries and the style head, whereas some Asclepiadeae lack it entirely. In several Asclepiadeae the constriction at the base of the apical appendage of the anther is absent in mature flowers (e.g., Astephanus, Eustegia and Microloma), although in most cases investigated it is present in early developmental stages of the flower. In most genera this distinction is clear, and they may be placed easily in one of these tribes. In some instances, however, this distinction is blurred.

Some support for uniting the Ceropegieae and the Marsdenieae into a single tribe may be considered to be received from the molecular analysis by Sennblad and Bremer (1996). However, in their study, out of the more than 500 species of Ceropegieae, two were sampled, and of the Marsdenieae (about 570 species), three species were tested. It is difficult to see how levels of sampling as low as this can possibly be considered to represent the position in such species-rich and diverse tribes, and this is not considered to constitute serious evidence that the two tribes should be united. Once further data have been amassed, the position should be reviewed.

In the case of Tylophora, N. E. Brown (1907-1909: 765) observed some species with erect and others with pendulous pollinia, and he confessed to being unable to decide which orientation the pollinia had in yet other cases (as a consequence, he abandoned Tylophoropsis, which we follow below). With respect to its pollinaria, Tylophora therefore is in limbo between the two tribes. In Tylophora the pollinia are mostly shortly ellipsoidal to nearly spherical, the caudicles are very thin and often short, and the corpuscle is mostly very small and frail. All of these suggest that this pollinarium is unspecialized and primitive and that it is from such structures that the more advanced pollinaria in the Asclepiadeae and Marsdenieae have arisen. In the species of Tylophora that we have examined, we found a relatively long neck (short in a few cases) between the style head and the ovaries. In many there is also a horizontal incision between the anther and its apical appendage; it must be noted that this has not always been found in mature flowers (and perhaps needs to be searched for in small buds) and that it is more prominent in species with larger and more obviously pendulous pollinia. Additional characters listed by Kunze (1996) that support a position in the Asclepiadeae for Tylophora are: the lack of endothecial tissue in the guide rails, and the degree of reduction of the endo- 
thecium around the locules and in the structure of the guide rails. Thus, despite the somewhat equivocal nature of these characters for Tylophora and its somewhat intermediate position between the Marsdenieae and the Asclepiadeae, it is included here among the Asclepiadeae.

Another awkward case is Karimbolea verruculosa. Here the shortly ellipsoidal pollinia are erect. The corona contains elements beneath the guide rails (an outer corona) and extensive inner parts and seems to be fairly typical of those found in Cynanchum. Unfortunately, none of the published illustrations (Liede et al., 1993) shows the relative position of these coronas on the staminal tube; nor do they show the style head and ovaries or the anther appendages, which might assist in deciding on the systematic position of Karimbolea. Nevertheless, it seems that this species is merely an aberrant member of $C y$ nanchum (consequently belonging to the Asclepiadeae), which has retained the basal position of the pollinia. A position in the Asclepiadeae was also proposed by Liede et al. (1993) and accepted by Omlor (1998).

Marsdenia is by far the largest genus in the tribe (ca. $250 \mathrm{spp}$.) and also has the widest distribution, being found in both the Old World and the New World. Various complexes of species have sometimes been treated as separate genera. Especially industrious in creating new genera were Schlechter (see Nicholas, 1992 for an enumeration of his many papers) and Bullock (1963). Taken over the whole range, however, many of the differences break down, and for this reason several of the segregate genera are mostly not recognized today. Both Rothe (1915) and Forster (1995) recognized a very broadly circumscribed Marsdenia, and Forster's (1995) broad concept of Marsdenia is used here.

The most comprehensive survey of the Marsdenieae is the recent doctoral dissertation by Omlor (1998), which provides an overview of the tribe. In addition to the characters mentioned above that are commonly used to distinguish the Marsdenieae from the Asclepiadeae, characters of the seed coat were found to be useful (Omlor, 1998: 58-63). Of particular interest was the finding that the surface of the seed coat is smooth and hairless in the Marsdenieae. In contrast, the surface of the seed in "the Tylophora group" (including Tylophora, Merrillanthus, Pentastelma, Sphaerocodon, and Vincetoxicopsis) has clusters of hairs of the type found in some genera in the Asclepiadeae. This is yet further support for the transfer of Tylophora and these genera to the Asclepiadeae.

A second group of genera that Omlor (1998) excludes from the Marsdenieae is what he refers to as "neotropical intermediate genera." This group includes Anomotassa, Barjonia, Blepharodon. Jobinia, Nephradenia, Petalostelma, and Vailia, all of which he moved to the Asclepiadeae. W. D. Stevens (pers. comm.) is also convinced that most of these belong in the Asclepiadeae, so we have accepted this here.

The very large tribe Asclepiadeae is cosmopolitan but with particular concentrations of species in Africa and the New World. It consists of a group of genera surrounding Asclepias, which have large and conspicuously flattened pollinia (in fact the largest pollinia in the Asclepiadoideae are found here in Pachycarpus and Calotropis), where pollinia are very obviously pendulous. The African component of this group was revised by N. E. Brown (1902-1903, 1907-1909), who united most of the genera under Asclepias. It was partly revised by Bullock in the 1950s (for a listing of his relevant papers, see Dyer, 1975: 474), who tried to reorganize them into many smaller, segregate genera. Bullock gave up his attempt before it was complete. It was taken up again briefly by Kupicha (1984) but otherwise has languished in neglect, so the taxonomy of this part of the tribe is especially disorganized.

The remaining, possibly more plesiomorphic genera, appear to form a cline from the larger pollinia of the Asclepias alliance toward the state in Tylophora and the other basal genera of the other tribes, where the pollinia are small and ellipsoidal, and it can be difficult to discern whether they are pendulous or erect. Liede (1997) has made a preliminary phylogenetic study 
of the Asclepiadeae, in which she defined the subtribes and reduced numerous genera to synonymy. However, Fishbein and Levin (1997) have indicated that there is little justification at this juncture to sweep so many of these little-known genera into synonymy until they have been more thoroughly studied. Most of Liede's synonyms are not, therefore, incorporated into this classification.

The Gonolobeae are exceptionally poorly known, and even the recent survey by Vethacke (1994) fails to throw much light on how they may be separated from the other tribes. The characterization of this tribe in the key of Bruyns and Forster (1991) has been shown to be incorrect by Kunze (1995). Thus it is necessary to fall back on the characterization by Woodson (1941), which is based entirely on features of the pollinarium: the horizontal (rarely pendulous) pollinia (which are broad rather than long), with a hyaline insertion crest and usually at least one partly concave face. Kunze (1995) has shown that only this insertion crest becomes lodged in the guide rail and that growth of the pollen tubes takes place through the concave face of the pollinium. We have verified this in Gonolobus gonocarpus, but it needs to be tested more widely across the tribe. Unfortunately, in many of the cases investigated, Vethacke (1994) failed to show the natural position of the pollinia in the anthers, which, according to Woodson (1941), is one of the important features of the tribe. Another feature that Woodson mentions is the sculptured faces of the pollinia; and this, too, is not very clear in many cases illustrated by Vethacke. In the few cases we have examined, and in the few instances in which one may make this out from Vethacke's illustrations, it appears that there is a horizontal groove at the base of the anther appendage and that the style head tapers off into the ovaries as it usually (but not always) does in the Asclepiadeae. Vethacke illustrated many of the follicles, and these appear also to resemble closely some of those in the Asclepiadeae. A case could, therefore, be made for subsuming the Gonolobeae within the Asclepiadeae. Swarupanandan et al. (1996) proposed a division of the Asclepiadaceae (which excluded the Periplocaceae) into three tribes: Secamoneae, Stapelieae, and Asclepiadeae. The Marsdenieae were included in the Stapelieae; and the Gonolobeae, in the Asclepiadeae.

The Stapelieae were defined by pollinia attached to the caudicles at their bases, anther sacs not embedded in the tissue of the anther wings, anther wings always below the level of the anther sacs, and style head separated from the ovaries by a sharp constriction, with the gynoecium devoid of a "true style." In the Asclepiadeae, pollinia were said to be attached to the caudicles at their apex, anther sacs are partly embedded in the tissue of the anther wings, the anther wings form a collar around the anther sacs, and the gynoecium has "two true styles" and lacks a constriction beneath the style head (Swarupanandan et al., 1996: 362).

It is now fairly well known that the guide rails (anther wings) are basal elongations of the dorsal pollen sacs (Kunze, 1996; Omlor, 1996). Therefore, it is impossible for the anther sacs to be "embedded in the tissue of the anther-wings." We are also quite unable to establish any justification for the statement that the anther wings form a "collar" around the anther sacs, and nowhere do the authors show what they mean by this "collar."

The statement that the pollinia are attached to the caudicle at their apex is not correct for the Asclepiadeae. The many pollinaria illustrated by Kupicha (1984) demonstrate clearly how variable the position of attachment of the caudicle to the pollinium may be in the Asclepiadeae: from the apex to near the middle of the outer edge. Kunze (1995) has shown that the pollinia in the Gonolobeae are laterally elongated (i.e., broad rather than long) and are attached to the caudicle not at their apex but near the middle of the outer edge. In the Ceropegieae s.str. the caudicle is not attached at the base of the pollinium. This is often true in the Marsdenieae (e.g., in Stigmatorhynchus, Bruyns, 1995), but in the Ceropegieae the attachment is usually toward the base but below the outer edge (see also Bruyns, 1995 for examples). 
The treatment by Swarupanandan et al. (1996) of the pellucid margin (hyaline insertion crest) on the pollinium is particularly worrisome. They claim (p. 336) that it is "generally absent from the Asclepiadeae and Gonolobeae." Kupicha (1984) demonstrated that there is a hyaline insertion crest in many cases in the Asclepiadeae s.str. It is well known in the widespread and common genus Pergularia, and Kunze (1995) showed it to be present in many Gonolobeae as well. Swarupanandan et al. (1996: 336) also claim that "the Marsdenieae are devoid of the pellucid tip/margin," which ignores its widespread occurrence in the large genus Hoya. This level of inaccuracy renders any other conclusions that they may arrive at rather doubtful.

Probably the only potentially useful character to come out of the long paper by Swarupanandan et al. (1996: 343-345) is the attenuated part between the ovaries and the style head, which they term the "true style" and the "pseudostyle." The use of these two terms is not clearly justified. In addition, they make much of a constriction beneath the style head. This abscission zone, at which the style head later separates from the developing follicles, is present, in more or less conspicuous form, throughout the Asclepiadoideae. Nevertheless, the presence or absence of a "true style" is used as a new character to separate the Ceropegieae and Asclepiadeae. However, its usefulness is, in fact, very limited: in several Asclepiadeae (most notably Eustegia and Emicocarpus) the style head is sessile on the ovaries; in several Ceropegieae (Stapelieae of Swarupanandan et al., 1996) (most notably in Orbea, but also in Macropetalum, for example) there is a similarly long neck between the ovaries and the style head, and the abscission zone beneath the style head is not conspicuous.

Liede (1997) has formalized the proposal by Swarupanandan et al. (1996), reducing the Gonolobeae to a subtribe of the Asclepiadeae. The molecular study of Sennblad and Bremer (1996) show the Gonolobeae to be nested within the Asclepiadeae, but only two species of Gonolobeae (out of about 400) and eight (out of about 1,000) species of Asclepiadeae were sequenced. This is again a level of sampling that is so low as to be meaningless. More comprehensive sampling has been carried out by K. Potgieter (1999) and this once more supports the inclusion of the Gonolobeae within the Asclepiadeae. In view of the lack of clear morphological differences between the two tribes, they are placed together here.

\section{CORONAS WITHIN THE APOCYNACEAE S.L.: HOMOLOGIES AND INTERPRETATIONS}

Liede and Kunze (1993: 277) proposed a new classification of coronas in the Asclepiadaceae s.str. According to the position of these structures, they distinguished four kinds of corona: corolline $(\mathrm{Cc})$, staminal $(\mathrm{Cs})$, interstaminal $(\mathrm{Ci})$, and annular $(\mathrm{Ca})$.

We have several problems with this classification. Liede and Kunze stated that "judged from topographic as well as ontogenetic properties," $\mathrm{Ca}$ is a "second element within the corolline corona type" (Liede \& Kunze 1993: 277). It would then have been more logical to have baptized $\mathrm{Cc}$ and $\mathrm{Ca}$ as $\mathrm{Ccl}$ and $\mathrm{Cc} 2$. However, our problem with this is more fundamental; namely, that from the literature and from our own experience of these plants we can find no evidence that $\mathrm{Ca}$ is not homologous to $\mathrm{Cc}$. In particular, no cases are known to us in which $\mathrm{Ca}$ and Cc occur together. Furthermore, Kunze (1990: figs. 82, 97) illustrated the early stages of $\mathrm{Cc}$ in Hemidesmus and Leptadenia, and in both of these it is first visible as a low ridge of uniform height that spans the area below the sinuses of the lobes. In stapeliads in which $\mathrm{Ca}$ is poorly developed, it is also a low ridge below the sinuses of the lobes (e.g., Hoodia currorii [Bruyns, 1993: fig. 26A]), and only in cases in which the annulus is more highly developed does it form a continuous, ringlike structure around the mouth of the tube. There seems, therefore, to be considerable similarity between the early stages in the $\mathrm{Cc}$ and some of the poorly developed annuli $(\mathrm{Ca})$ in stapeliads. 
Kunze (1990) suggested that the Cc were homologous in the Apocynaceae s.str., Periplocoideae, and the Asclepiadaceae s.str. In his study, however, he included only one type of corolline corona for the Apocynaceae s.str. Actually, there are various types of corolline coronas in the Apocynaceae s.str., and their homology is by no means established. The great majority of coronas is found in the alternipetalous sectors of the corolla tube (i.e., the same sectors from which the stamens arise). Within this group, one can distinguish between those found in the upper portion of the corolla tube, which develop from the postgenitally fused petal primordia, and those situated lower down in the immediate region of staminal insertion, where the postgenitally fused region of the corolla meets the congenitally fused region, which is composed of the united petal and stamen primordia. (For more information on the significance of congenital and postgenital fusion in the ontogeny of the corolla tube in Apocynaceae, see Boke, 1948; Nishino, 1982.) The first type, those formed in postgenitally fused regions and involving only the petal primordia, is the type of corolline corona considered by Kunze (1990) to be homologous to that found in the Periplocoideae. Expression of this type of corona varies: flat, petaloid ligules, which may or may not be united (e.g., Melodinus, Nerium, Strophanthus, Stephanostemma, Wrightia); a small, thin flap that forms a pouch in the petal sinus (e.g., Apocynum, Beaumontia, Vinca); a thickened annulus (e.g., Kopsia, Craspidosperma); small knobs or lobules (e.g., Dyera, Diplorhynchus, Pycnobotrya).

The coronas that arise in the region near the confluence of the postgenitally and congenitally fused parts of the corolla tube are more complex. In the mature flower in this region one cannot easily distinguish between what is of staminal and what is of corolline origin, due to elongation after initiation. Detailed ontogenetic studies of this type of corona are lacking. This type of corona is usually composed of a lobule or fingerlike projection directly above each stamen, and it is especially well represented in the higher Apocynoideae (sensu Sennblad et al., 1998) (e.g., Baissea, Motandra, Prestonia, Cycladenia). In other taxa the region of the corolla confluent with and just below staminal insertion is enlarged and in some cases (e.g., Motandra, Aganosma) forms a ring, similar to that typically found in the Periplocoideae. Other taxa have outgrowths in the lower, congenitally fused region of the corolla tube below the insertion of the stamens. These may be in the form of a protuberance below the insertion of the stamen (as in Cerbera or Thevetia), forming a ledge or winglike rib that begins below the insertion of the stamen and continues for some distance down the corolla tube.

More than one type of corolline corona may be present in a particular taxon. Prestonia, for example, is characterized by having a thickened annulus in the throat at the level of the petal sinuses. But it also normally has a large fingerlike lobe lower down on the corolla tube, just above the insertion of each stamen. Baissea has small pouches in the petal sinuses and a lobule just above and behind each anther. Motandra has a lobule directly behind the anther and enlarged staminal feet, similar to those found in the Periplocoideae.

Kunze (1990) has demonstrated that the corona in Periplocoideae is corolline in origin. It normally arises in the petal sinuses and thus may be homologous to the sinal corolline corona in the Apocynaceae s.str. However, in most Periplocoideae, the flowers tend to be rotate. The upper, postgenitally fused region of the corolla tube is not developed. The petal sinuses, therefore, are almost in the same position as the insertion of the stamens. Is the corona in the Periplocoideae, thus, homologous to the sinal corona or to one of the other corona types lower down and associated with the stamens in the Apocynaceae s.str.? To confuse the issue further, there are two conflicting examples of Periplocoideae with a relatively long corolla tube. The first is Ectadium (Fig. 5), in which the corona lobes are in the petal sinuses at the top of the corolla tube. The second is Cryptostegia, in which the corona lobes sit at the base of a corolla tube about $2 \mathrm{~cm}$ long. Are the coronas in these two taxa homologous? Another problematic 
taxon is Cryptolepis oblongifolia (Fig. 5), which has a corona lobe in the petal sinus as well as one directly above each anther, associated with the staminal foot.

In the Ceropegieae, scalelike corolline coronas are known in Leptadenia, and some very unusual ones are found in Pentasachme (Bruyns \& Forster, 1991: figs. 1D-E), the nature of which is not fully understood. We suggest that the annuli found in many Ceropegieae (and possibly the Gonolobinae) could be homologous to the corolline corona of some more basal Apocynaceae. Another problem are those taxa of Apocynoideae that possess a staminal corona (e.g., Kibatalia, Vallaris).

Although these are rare, there is no doubt that they exist. Kunze (1990:34) was aware that some Apocynoideae have staminal coronas. Nevertheless, it seems that he "swept this fact under the carpet," for he then made the statements that the "development of staminal and annular coronas is autapomorphic in Asclepiadaceae" and that "the asclepiad staminal corona is a structure sui generis that cannot be homologised with coronas in Periplocaceae and Apocynaceae" (Kunze, 1990: 7, 35). Because staminal coronas exist in the Apocynoideae, these statements are incorrect. Furthermore, these coronas in the Apocynoideae are omitted from the discussion in Liede and Kunze (1993), so that in that paper one is left with the impression that they do not occur in the Apocynaceae s.str. at all.

In a few cases (e.g., Apocynum, Microloma) coronas are found in the epipetalous sectors (i.e., the sectors of the corolla tube alternating with the stamens). These are not included in Liede and Kunze's (1993) terminology. In Microloma Bruyns and Linder (1991) called these "corolline," but they are most likely not homologous to the coronas found in the staminal sectors. Nevertheless, detailed analyses are lacking.

Determining homology of these various coronas - even within one subfamily - is a daunting task and cannot be easily resolved, even with careful ontogenetic study. Trying to "prove" homology between coronal structures in the Apocynaceae s.str. and the Periplocoideae and Asclepiadoideae or Secamonoideae is an exercise in futility at this stage, because the necessary data are lacking. For students interested in this type of work, this would be an excellent opportunity to make a truly significant contribution to our understanding of this group.

Another difficulty of the corona classification of Liede and Kunze (1993) is that their exposition of the relationship between the two kinds of gynostegial coronas, $\mathrm{Ci}$ and $\mathrm{Cs}$, is confusing. In Kunze (1990: 31) the interstaminal corona ( $\mathrm{Ci}$ ) is referred to as a "ring around the basal staminal column." In Liede and Kunze (1993: 281) these gynostegial coronas are said to consist of "two fundamental elements" ( $\mathrm{Ci}$ and $\mathrm{Cs}$ ) that are "combined by means of two developmental processes. The first process is the fusion between $\mathrm{Cs}$ and $\mathrm{Ci}$, leading for example to the cup-shaped coronas [C(is)] in Cynanchum. The second process leads to a vertical separation of elements in the staminal sector, resulting in an annular corona at the base of the gynostegium combined with five separate staminal coronas." Ringlike $\mathrm{Ci}$ are not mentioned in this account. It is, however, mentioned that "the homology of similar corona types ... needs to be ascertained by ontogenetic studies" (p. 282).

Liede and Kunze (1993) presented no ontogenetic evidence for these claims; nor have we been able to locate any evidence in the literature. To investigate the veracity of these statements, we examined the ontogeny of the coronas in two species of Cynanchum ( $C$. africanum and $C$. zeyheri) in which the mature corona forms a fairly complex, cupular structure around the gynostegium. One of these is illustrated here (Fig. 10A-D). The structure starts off as five very shallow and broad bays beneath the guide rails, with the least swollen part exactly below the center of the anther. These develop into a continuous, ascending cup, with the anthers rising out of the cup on a stipe. Both this cup and the staminal stipe elongate, with progressively more complicated structures developing around the mouth of the cup. 

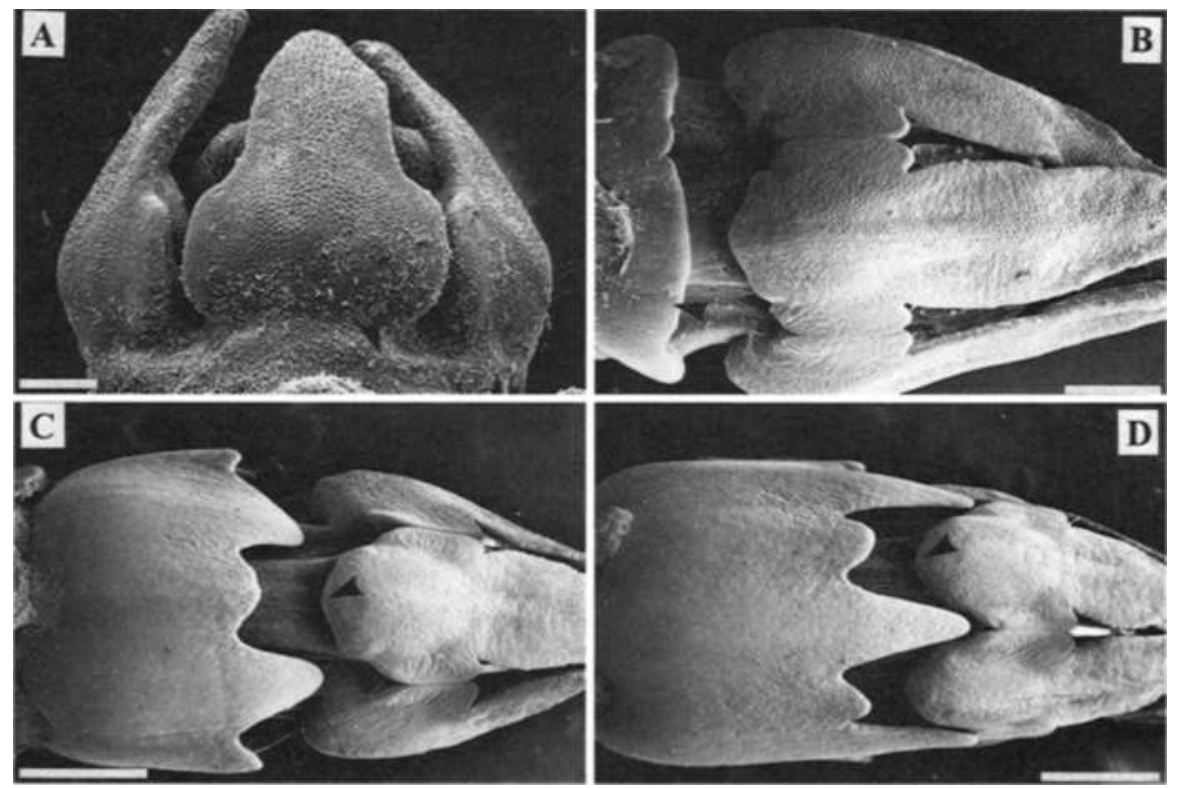

Fig. 10. Development of the gynostegial corona in Cynanchum africanum (P. V. Bruyns). (B-D are placed on their sides.) A. Outer corona just beginning to appear (arrowed) beneath guide rails. B. Outer corona forming continuous cup (arrowed) around base of gynostegium. C-D. Further development of outer corona (mature corona not shown) with increasingly complex rim; the slightly descending swellings (arrowed) on backs of anthers at the level of the base of the guide rails are probably rudiments of an inner corona. Scales (approx.): A, $100 \mu \mathrm{m} ; \mathrm{B}, 200 \mu \mathrm{m} ; \mathrm{C}-\mathrm{D}, 500 \mu \mathrm{m}$.

For comparison we have illustrated a similar ontogenetic series for the gynostegium of Sarcostemma viminale (Fig. 11 A-H). Here the first coronal structure observed is a small, baylike swelling beneath each rudimentary guide rail. This then rapidly spreads around the gynostegium to form a continuous ring, which we shall term the outer corona. At a later stage the staminal (or "inner") corona begins to appear at the base of the anther but still well above the outer ring. These two structures continue to expand until mature, with the back of the inner lobes gradually spreading downward with a ridge of tissue so as to link up partly with the outer ring.

How do these cases compare with what Liede and Kunze (1993) claimed? First, in the formation of some cupular coronas in Cynanchum there is no evidence at all that fusion between $\mathrm{Cs}$ and $\mathrm{Ci}$ has taken place. The complicated "frilly" structure that arises is a consequence of later differentiation in the structures already present. Second, it seems reasonable to conclude that the ringlike corona seen in $C$. africanum is homologous to the ringlike corona in $S$. viminale and that these are all outer (interstaminal) coronas. Third, the inner (staminal) corona, which arises somewhat later than the outer and somewhat above it (behind the anther) is absent in $C$. africanum.

Liede and Kunze (1993) described the corona of $S$. viminale in some detail (though they do not appear to have investigated its ontogeny) and gave a formula for it as "C(is) + Cs." The presence of " $\mathrm{s}$ " in the first expression suggests that the Cs played some role in forming the 

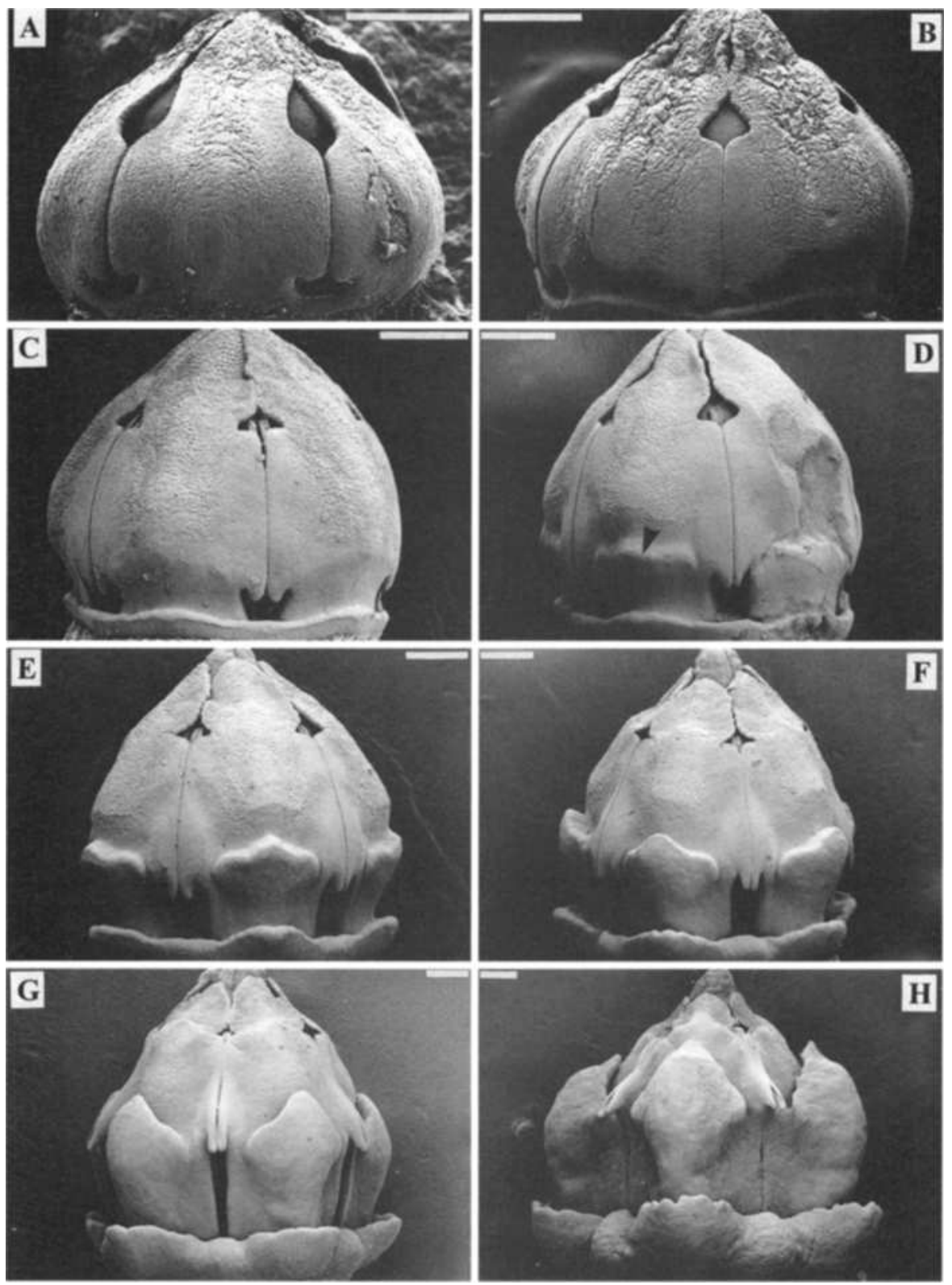

Fig. 11. Development of the gynostegial corona in Sarcostemma viminale (P. V. Bruyns 7636). A. Outer corona only present as small bumps beneath guide rails (arrowed). B-C. Outer corona spreads around gynostegium to corm continuous ring (arrowed). D. Inner corona (arrowed) appears well above outer corona at level of base of guide rail. E-H. Development of coronas to maturity, with outer remaining ringlike and inner well above it but gradually swelling dorsally to spread down to outer. Scales (approx.): A-H, $200 \mu \mathrm{m}$. 
C(is). The above ontogenetic investigation does not bear this out. In our opinion, it is far simpler to refer to a ringlike outer corona and the five discrete, swollen lobes of the inner corona behind the anthers and slightly higher up on the staminal column.

\section{Conclusion: The Apocynaceae s.l.}

The Asclepiadaceae has traditionally been separated from the Apocynaceae because of the presence of complex translators and pollinia in the former and their absence in the latter. As our discussion above shows, however, this character exhibits a continuum between the two extremes. Furthermore, when a wider selection of characters is considered, this separation is again not supported. The distribution of character states for various relevant characters is given in Table I across the whole group. This demonstrates that in many of them there is a gradation from one family to the other (Endress, 1997).

In cladistic analyses based on morphological data (Endress \& Albert, 1995), on molecular data (Sennblad \& Bremer, 1996; Sennblad, 1997; Potgieter, 1999), or on morphological and molecular data combined (Civeyrel, 1996; Sennblad et al., 1998), the taxa traditionally included in the Apocyneae and Echiteae of the Apocynoideae (Apocynaceae) are found to be more similar to those in the Periplocoideae (Asclepiadaceae) than they are to the Rauvolfioideae (Apocynaceae). The cladistic view of classification is that it should reflect phylogeny and strive to recognize only monophyletic groups. A more traditional view of classification aims to identify discontinuities in characters and to group taxa according to these discontinuities at whatever level is applicable.

From both points of view the traditional treatment of the Apocynaceae and Asclepiadaceae as separate families is unsatisfactory. Simply recognizing the Apocynaceae and the Asclepiadaceae, as traditionally defined, as their own order or suborder (as proposed by Rosatti, 1989) does not remedy the problem, because the boundary between the two families within this order would remain artificial. In order to fulfill the criterion of monophyly, Sennblad (1997) proposed that all the asclepiads be included in the Apocynoideae, an arrangement that would at least make the resultant taxon monophyletic. However, although the survey by Sennblad (1997) is one of the most comprehensive molecular studies of the group to date, it is especially weak in the region of the interface between the former families Apocynaceae and Asclepiadaceae; that is, the critical groups of higher Apocynoideae (Apocyneae, Mesechiteae, and Echiteae) and basal asclepiads (Periploceae, Secamoneae, and Marsdenieae). One of the problems is that relatively few of the relevant taxa have been sampled. Another problem is that in some cases sterile plants have been used (e.g., Baissea. Cibirhiza), and these can be very difficult to identify with certainty. For example, a cultivated plant labeled as Fockea tugelensis of the Asclepiadoideae (and even verified as such by a specialist) proved, on closer examination, to be Petopentia of the Periplocoideae. This misidentification was noticed only because of the unexpected position of Fockea tugelensis in the tree generated by molecular data (Sennblad, 1997).

In a recent paper by Civeyrel et al. (1998), which involved 15 taxa from the apocynacs and 22 taxa from the asclepiads, the three main subdivisions within the asclepiads-Periplocoideae, Secamonoideae and Asclepiadoideae-were supported. In addition, the asclepiads formed a monophyletic group. However, it is noteworthy that only two taxa that could be considered to lie close to the large subfamily Apocynoideae were included in this study. In further continuing studies, which include more taxa and additional genes, resolution at the interface is still unsatisfactory (Potgieter \& Albert, 1998b; Potgieter, 1999), and there is even some indication that the 


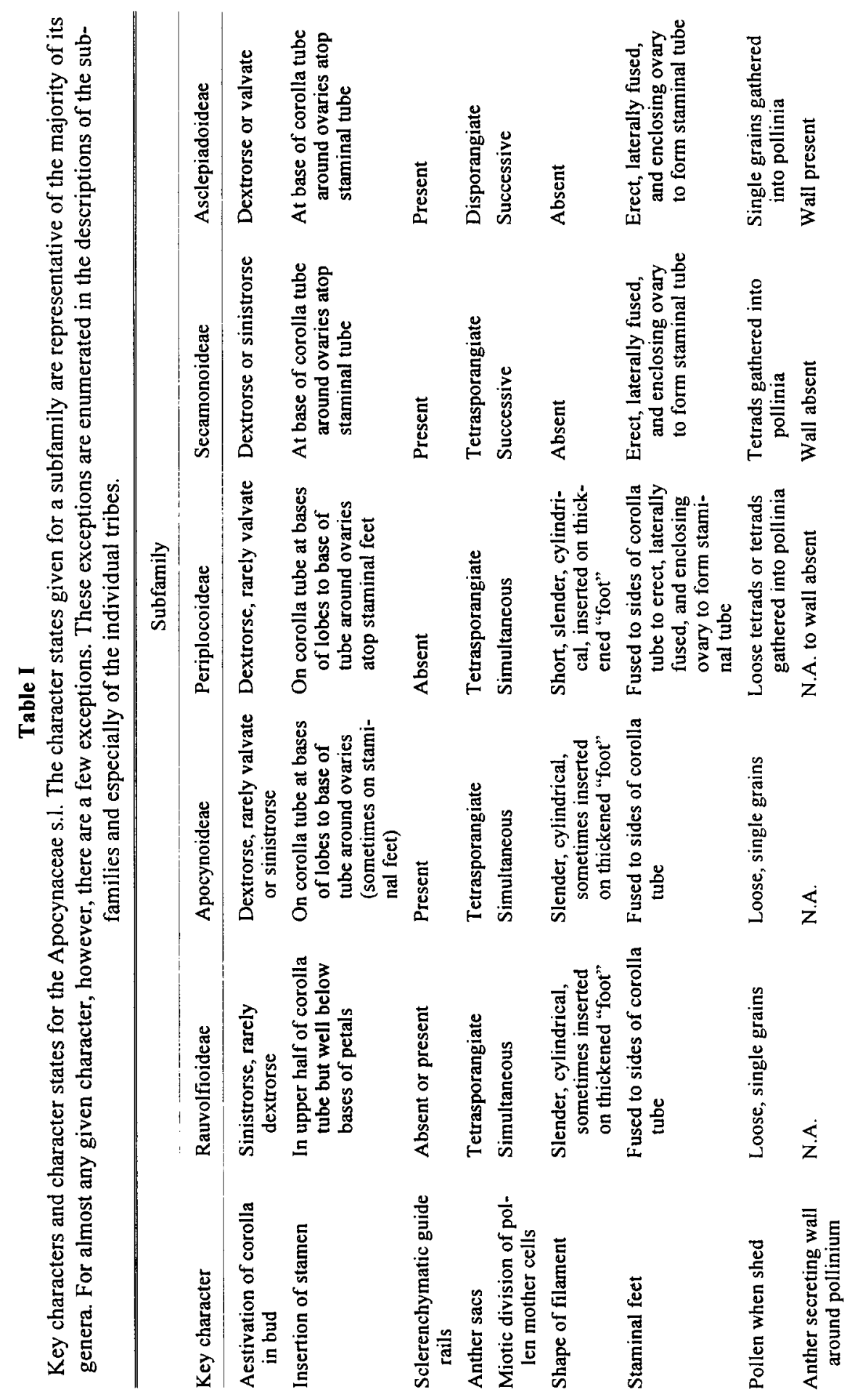




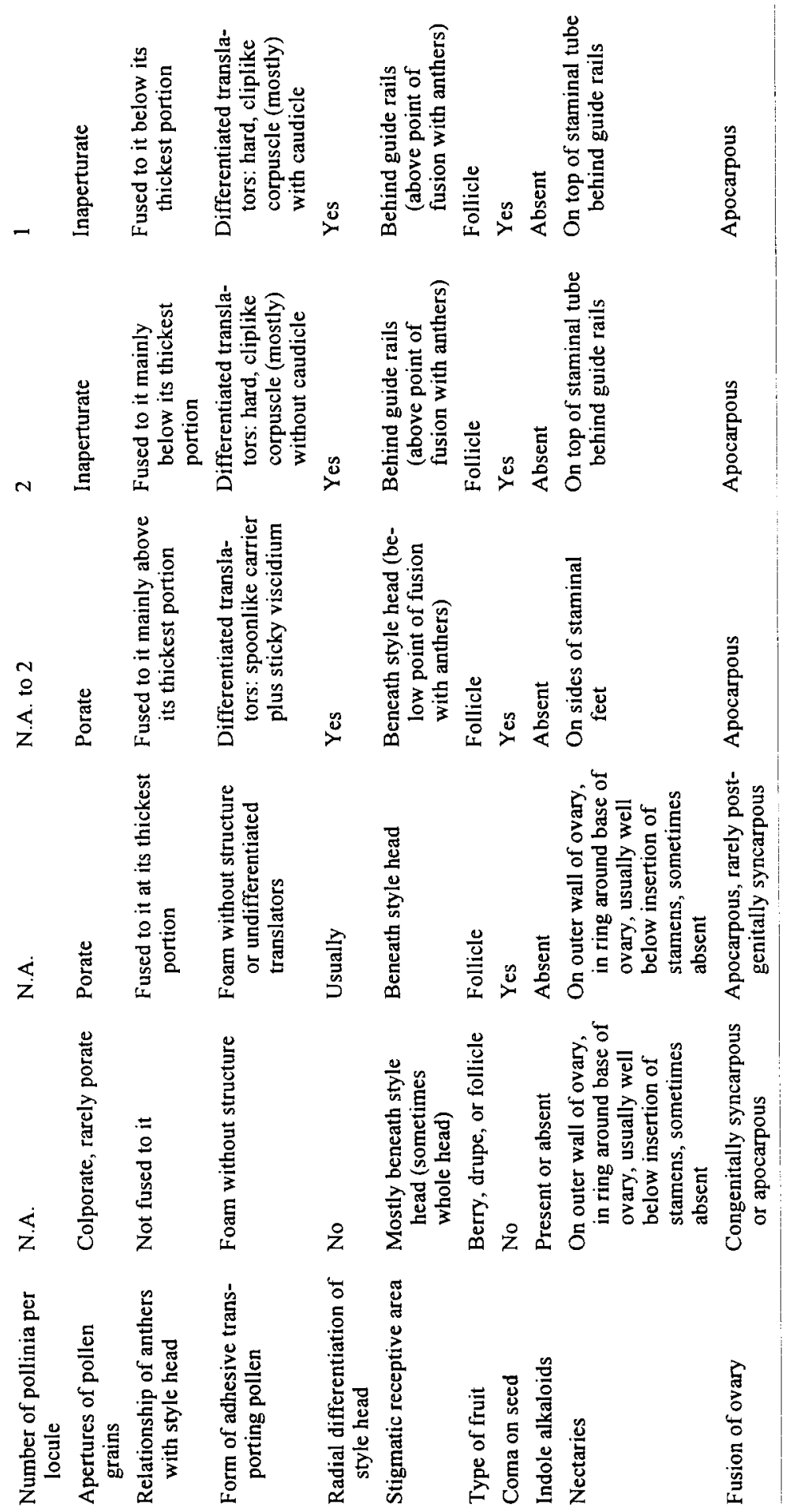


asclepiads may be biphyletic (Sennblad, pers. comm.). Thus the question of the monophyly of the asclepiads has still not been satisfactorily answered.

One of the most interesting aspects of the paper by Civeyrel et al. (1998) is the possible taxonomic solutions put forward for a new delimitation of the group, based on the results of her study and including only monophyletic groups. There are three possible solutions: it is one all-embracing family; all monophyletic units are given the rank of family; or an intermediate limit is drawn between the Apocynoideae and the Rauvolfioideae, with the Apocynoideae and asclepiads becoming the new Apocynaceae and giving the remaining polymorphic Rauvolfioideae groups the rank of family. Clearly, the most moderate of the three solutions is to make one big family. The excuse sometimes heard (e.g., Swarupanandan et al., 1996)that a combined Apocynaceae and Asclepiadaceae would result in a family too large to handle-is illogical. If the two families were combined, the resultant entity would contain 424 genera. This would make the Apocynaceae s.l. the seventh-largest angiosperm family (if size is assessed on the number of genera included), which is slightly smaller than the Apiaceae. The families Asteraceae, Orchidaceae, Fabaceae, Poaceae, and Rubiaceae all have significantly more genera (Brummitt, 1992).

In our opinion, a unified family best reflects the phylogeny of the group as we understand it and is the only acceptable form from the cladistic perspective. However, because of the lack of resolution at the interface, we believe that it would be injudicious at this stage to include all of the asclepiads in the Apocynoideae, as proposed by Sennblad (1997). A similar conclusion was reached by Potgieter (1999).

We therefore propose the following classification. As discussed above, it is based, for the most part, on morphological characters supplemented occasionally (where support was strong) by molecular results. All taxonomic categories are based on a suite of characters and only well-supported changes were made. In the Apocynaceae s.str., the tribal delimitation of the Rauvolfioideae presented here differs significantly from previous classifications. In almost all cases this is because in earlier classifications the rauvolfioid tribes were based on characters of the fruit and did not recognize convergence due to selective pressures on dispersal mechanisms. In addition, some tribes must be renamed, because the earliest validly published name has not always been used. In the Apocynaceae s.str., major changes include: redefinition of the Plumerieae to include the traditional Cerbereae, Allamandeae, and Plumeriinae; recognition of the Alstonieae as distinct from the Plumerieae and Melodineae; inclusion of the Ambelanieae and Macoubeeae within the Tabernaemontaneae; the Carisseae divided into three tribes (Willughbeieae, Hunterieae, and Carisseae); recircumscription of the Alyxieae (including Chilocarpus and Plectaneia) and their segregation from the Vinceae; separation of the Malouetieae from the Wrightieae; and recognition of the tribe Mesechiteae.

Because of the above-mentioned uncertainties in the region of the interface between the former families we wish to maintain the asclepiads as three subfamilies: Periplocoideae, Secamonoideae, and Asclepiadoideae, with the last further divided into the three tribes: Marsdenieae, Ceropegieae, and Asclepiadeae. In the "Asclepiadaceae s.str.," apart from the changes in the ranks of the groups, the only significant changes we have made is the abandonment of the tribe Fockeeae, the incorporation of its two genera, Fockea and Cibirhiza, back into the Marsdenieae, and the inclusion of the Gonolobeae in the Asclepiadeae.

We have refrained from erecting subtribes at this stage. Whereas in some tribes the relationship between the genera are clear, in others more study is needed. We view our contribution not as the final word but as a framework, which is to be modified as new results dictate. 


\section{Taxonomic Treatment}

Apocynaceae Jussieu, Gen. Pl. 143 (1789).

Woody climbers, vines, perennial herbs, trees or shrubs, more rarely annuals. Latex usually milky, sometimes clear, rarely yellow or red. Leaves simple and entire, normally petiolate, rarely sessile, usually opposite, rarely alternate or whorled; stipules absent or small and caducous, almost always with toothlike colleters in axil of leaf, sometimes on petiole, in a cluster adaxially at juncture of petiole and base of lamina or along midrib above, rarely with domatia abaxially in axils of veins. Flowers perfect, rarely functionally dioecious, actinomorphic, very rarely slightly zygomorphic, almost always 5-merous except for gynoecium of two carpels (rarely more). Calyx mostly with colleters within at base. Corolla salveriform, infundibuliform, tubular, or rotate. Petals usually contorted in bud, either dextrorse or sinistrorse, more rarely valvate. Corolline or gynostegial coronas often present. Stamens inserted on corolla tube, on staminal feet, or on staminal tube. Anthers mostly highly elaborated and with lignified guide rails and normally with apical connective appendage, mostly attached to stylehead, forming gynostegium (free from style head and mostly without guide rails in Rauvolfioideae). Pollen when shed in single grains, in tetrads, in tetrads collected into weakly cohesive pollinia or tightly bound into pollinia with waxy outer covering (ectexine). Nectar secreted in alternistaminal troughs on staminal tube or staminal feet or from disclike nectary around base of ovary, more rarely from sides of ovary or absent. Ovary mostly apocarpous, superior to subinferior; placentation marginal when ovary apocarpous, parietal or axile when syncarpous, upper part of carpels fusing postgenitally to form complex style head that produces adhesive for pollen transport, with pollen-trapping basal collar and/or pollen-presenting upper crest present in many Rauvolfioideae and Apocynoideae; stigma mostly on underside of style head, often restricted to five chambers behind guide rails, but laterally uniformly receptive in some Rauvolfioideae. Adhesive a formless, sticky foam or mucilage, or as five translators with scooplike pollen receptacle and sticky base, or as five hard clips (corpuscules), usually accompanied by five pairs of flexible arms (caudicles). Fruit mostly a pair of ventrally dehiscent follicles (often only one due to abortion) (rarely a capsule), with small seeds with a micropylar coma, rarely with a chalazal coma or ecomose (fruits in Rauvolfioideae drupes, berries, follicles, or capsules; seeds usually ecomose, naked, winged, or arillate).

\section{A. KEY TO THE SUBFAMILIES OF THE APOCYNACEAE S.L.}

1. Anthers adnate to style head; corolla-lobe aestivation in bud typically dextrorse (overlapping to the right) or valvate, rarely sinistrorse; fruit dehiscent, almost always apocarpous, a pair of follicles, sometimes reduced to one by abortion or postgenitally fused; seeds small, compressed, almost always with coma (tuft of hairs) at one end . . . . . . 2

1. Anthers free from style head; corolla-lobe aestivation in bud typically sinistrorse (overlapping to the left), rarely dextrorse; fruit dehiscent or indehiscent, syncarpous or apocarpous, a berry, drupe, follicle, or capsule; seeds naked, with wings, or arils, but almost never with coma at one end . . . . . . . . . . Rauvolfioideae 2. Nectaries, if present, in ring around base of ovary; anthers 4-locular; pollen almost always shed as monads; style head secretions for pollen transport normally a foamy adhesive or gummy, undifferentiated translators . . . . . . . Apocynoideae

2. Nectaries located in alternistaminal troughs on staminal feet or staminal tube; anthers 2-4-locular; pollen shed as tetrads or gathered into pollinia; style-head secretions for pollen transport forming differentiated translators with sticky end (viscidium) or consisting of a rigid clip (corpuscle) and two flexible

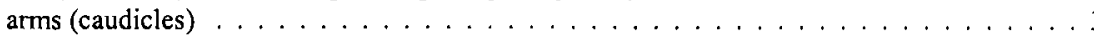


3. Anthers 4-locular, pollen shed as tetrads or, if gathered into pollinia, then

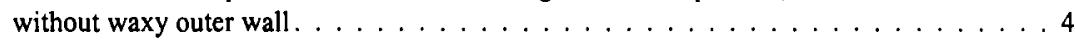

3. Anthers 2-locular, pollen enclosed in pollinia covered by waxy outer wall

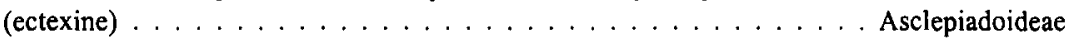

4. Translators with sticky end (viscidium), which adheres to pollinator for removal; pollen usually shed in tetrads, or occasionally in pollinia, from anthers onto spoon- or cornet-shaped receptacle of translator . . . . . . . Periplocoideae

4. Translators with hardened, cliplike corpusculum in which some part of pollinator's body becomes caught for removal; pollen gathered into 4 minute pollinia attached directly or indirectly to the corpusculum . . . Secamonoideae

\section{Rauvolfioideae Kostel., Allg. Med.-Pharm. Fl. 3:1054 (1834)}

Trees, shrubs, woody lianas or vines, rarely herbs. Latex usually milky, rarely reddish or yellowish. Leaves opposite, whorled, or alternate. Calycine colleters often lacking, when present usually in single series (but characteristically multiseriate in Tabernaemontaneae); corolla mostly salveriform, rarely with inflated throat (tubular campanulate or infundibuliform); corolla lobes mostly not inflexed in bud (except in some Tabernaemontaneae and Alyxieae); aestivation almost always sinistrorse; corona when present almost always in the staminal sector, usually of simple lobes or pouches in petal sinuses (rarely fused into annulus), sometimes lower down on corolla tube above stamen; anthers included in corolla tube, usually fertile to base (fertile in upper part only and with sterile lignified basal appendages in most Tabernaemontaneae), free from style head; ovary congenitally syncarpous or apocarpous, very rarely postgenitally syncarpous; stigma restricted to the base of the style head, or entire body of style head uniformly receptive. Nectaries surrounding base of ovary, adnate to outer ovary wall or absent. Fruit dehiscent or indehiscent; pericarp fleshy or dry; endocarp sometimes lignified, forming a stone around the seed(s); seeds generally naked or winged, testa glabrous or hairy, smooth, or pitted, ridged or rugulose, without coma (except in Haplophyton), sometimes with pronounced hilar furrow; endosperm smooth, sometimes ridged or ruminate. Pollen mostly 3-4-colporate, but typically porate and often with only 2 apertures in Alyxieae and a few Melodineae. Indole alkaloids often present, iridoid glycosides and cardenolides less frequently.

\section{Key to the tribes of the Rauvolfioideae}

1. Anthers usually sagittate at base and with lignified guide rails; fruit fleshy, either a pair of dehiscent follicles with arillate seeds or an indehiscent berry Tabernaemontaneae

1. Anthers rarely sagittate at base, without lignified guide rails; fruit fleshy or dry, berries, drupes, follicles, or capsules; arils absent (except in Chilocarpus) . . . . . . . . 2

2. Fruit indehiscent, a berry; leaves almost always opposite . . . . . . . . . . . 3

2. Fruit either indehiscent or dehiscent, but not a berry; leaves opposite,

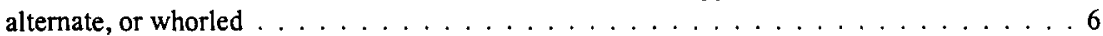

3. Ovary apocarpous, $2-5$-carpellate; pericarp fibrous . . . . . . . . . . Hunterieae

3. Ovary congenitally syncarpous, 2-carpellate (except in some Alyxieae);

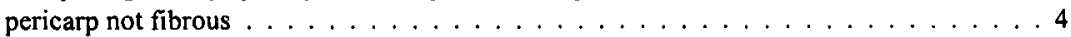

4. Placentas becoming lignified in fruit, forming woody partition; spines often present in leaf axils (Carissa); indole alkaloids absent . . . . . . . Carisseae

4. Placentas not lignified in fruit; without spines in leaf axils; indole

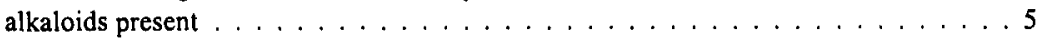
5. Corolline corona usually present; lianas without tendrils. . . . . . . Melodineae 
5. Corolline corona absent; trees, shrubs, or lianas (the latter often with tendrils), rarely rhizomatous subshrubs. . . . . . . . Willughbeieae

6. Anthers with latrorse dehiscence and often with caudate apical connective appendages . . . . . . . . . . . . . Plumerieae

6. Anthers with introrse dehiscence, normally lacking caudate apical appendages (but large, flat, apical appendages present in Vinca) . . . . . . 7

7. Pollen porate (inaperturate in Condylocarpon); corolla lobes often deeply inflexed in bud; style head without membranous basal collar; nectaries absent or indistinct from ovary; seeds not compressed (except in Plectaneia), usually with deep longitudinal hilar depression and ruminate endosperm; indole alkaloids absent . . . . . . . . Alyxieae

7. Pollen usually colporate; corolla lobes mostly not inflexed in bud; style head with or without basal collar; nectaries absent or present; seeds compressed or not; indole alkaloids present or absent. . . . . . 8 8. Seeds naked, sometimes with flattened edge, but without welldeveloped wing(s) or hairs on margin; fruit indehiscent and drupaceous or a pair of dehiscent follicles; style head mostly with basal collar; disc mostly present; herbs, shrubs, or trees. . . . . . Vinceae

8. Seeds mostly with well-developed (often membranous) wing(s) or with hairs on margin (but naked in Geissospermum, Vallesia, and Microplumeria and with coma at each end in Haplophyton); fruit usually a pair of dehiscent follicles (drupaceous in Vallesia); style head with or without basal collar; disc mostly absent or adnate; trees, shrubs, or lianas . . . . . . . . . . . . . . . . 9

9. Flowers large, showy; corolla usually $>2 \mathrm{~cm}$ long, often thick, waxy in appearance; ovary hemi-inferior in Plumeria, Himatanthus, and Mortionella; corolla tube without gaps above stamen insertion; placentas mostly lignified in fruit, forming woody partition; indole alkaloids absent. . . . . . . . . . . Plumerieae

9. Flowers small to medium sized; corolla usually $<2 \mathrm{~cm}$ long, usually thin, delicate in texture; ovary almost always superior; corolla tube sometimes with gaps above stamen insertion; placentas mostly not lignified in fruit; indole alkaloids present $\ldots \ldots 10$ 10. Corolline corona absent; anthers without apical or basal extensions; leaves often alternate or whorled, sometimes opposite; plants of the New World (except Alstonia) . . . . . Alstonieae

10. Corolline corona often present as small lobes in throat or ridges behind anthers; anthers sometimes with short, sterile apical appendages (Diplorhynchus, Dyera) or with short sterile appendages at apex and thecae bases (Pycnobotrya); leaves opposite or whorled; plants of the Old World . . . . . . . . . . . . . . . . . Melodineae

\section{a. Alstonieae G. Don, Gen. Hist. 4: 70, 86 (1838)}

Trees or shrubs. Latex usually milky, but often reddish or yellowish in Aspidosperma. Leaves alternate, whorled, or opposite. Calycine colleters absent; corolla salveriform or somewhat funnelform in Haplophyton; corolla-lobe aestivation either sinistrorse or dextrorse; corona absent; style head with or without a basal collar; ovary apocarpous or rarely syncarpous; disc absent, adnate, or inconspicuous. Fruit normally with dry pericarp and dehiscent, a pair of follicles or these rarely fused, but fruit fleshy in Geissospermum and Vallesia; endocarp usually not forming a stone (except in Vallesia); ovules several to numerous per 
carpel. Seeds various: thin and compressed with wing, or with hairs around margin, which often become longer at ends (Alstonia, Tonduzia, Laxoplumeria), or seeds not compressed and with coma at both ends (Haplophyton) or naked (Microplumeria, Vallesia). Endosperm smooth. Pollen 3-colporate. Secondary chemistry indole alkaloids. $x=10,11$. Distribution: Old World and New World, tropics, subtropics.

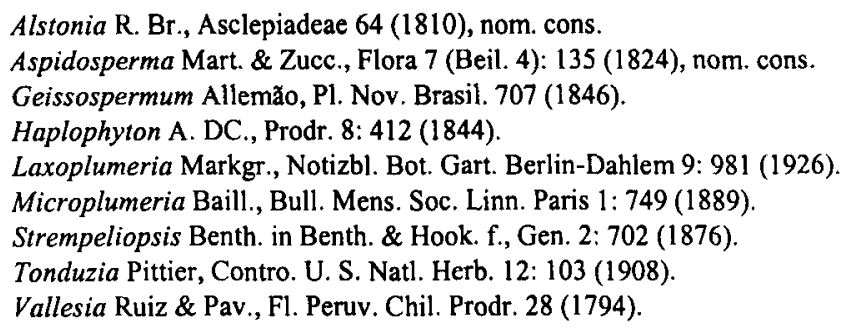

b. Vinceae Duby, Bot. Gall. 1: 324 (1828)

Trees or shrubs, more rarely lianas, vines, or herbs, with milky latex. Leaves whorled or opposite, rarely alternate. Calycine colleters absent; corolla salveriform; corolla-lobe aestivation usually sinistrorse (dextrorse in Kopsia, Neisosperma, and Ochrosia); corona absent; style head usually with stigmatic region beneath basal collar; disc normally present; ovary apocarpous (in some Rauvolfia spp. hemisyncarpous), often only one carpel maturing. Fruit either indehiscent, drupaceous with a fleshy pericarp and indurated endocarp forming a stone, or a pair of dehiscent follicles; seeds $1-4(-6)$ per carpel, rarely more, ovoid or compressed (the flat margins forming a ledge in Kopsia, Ochrosia, and Neisosperma). Endosperm usually fleshy and smooth (very thin or apparently absent in Kopsia). Pollen mostly 3-colporate. Secondary compounds indole alkaloids. $x=9,10,11,23$. Distribution: Old World and New World, tropics, subtropics, and temperate.

Amsonia Walter, Fl. Carol. 98 (1788).

Catharanthus G. Don, Gen. Hist. 4(1): 95 (1837).

Kopsia Blume, Cat. Buitenzorg 12 (1823) (nom. cons.).

Neisosperma Raf., Sylva Tellur. 162 (1838).

Ochrosia Juss., Gen. 144 (1789).

Petchia Livera, Ann. Roy. Bot. Gard. (Peradeniya) 10: 140 (1926).

Rauvolfia L., Sp. Pl. 1: 208 (1753).

Vinca L., Sp. Pl. 1: 209 (1753).

\section{c. Willughbeeae A. DC., Prodr. 8: 318 (1844)}

Trees, shrubs, or woody lianas, the last often with grappling tendrils, with milky latex. Leaves opposite; calycine colleters present or absent; corolla salveriform; corolline corona absent; corolla-lobe aestivation almost always sinistrorse; apical connective appendages of anthers often scarcely developed; style head usually with stigmatic region beneath basal collar, sometimes body uniformly receptive; ovary congenitally syncarpous; disc mostly adnate or indistinct from ovary. Fruit indehiscent, a berry with fleshy, nonfibrous pericarp and placentas usually pulpy in fruit; endocarp not forming a stone; seeds usually numerous, embedded in pulp, with or without longitudinal furrow; endosperm smooth or wrinkled longitudinally. Pollen (1-)3(-4)-colporate. Secondary chemistry indole alkaloids. $x=11$. Distribution: Old World and New World, tropics. 
Ancylobotrys Pierre, Bull. Mens. Soc. Linn. Paris, sér. 2, 1: 91 (1898).

Bousigonia Pierre, Bull. Mens. soc. Linn. Paris, sér. 2, 1: 35 (1898)

Chamaeclitandra (Stapf) Pichon, Mém. Inst. Franç. Afrique Noire 35: 202 (1953).

Clitandra Benth. in Hook., Niger Fl. 445 (1849).

Couma Aubl., Hist. Pl. Guiane Suppl. 39, t. 392 (1775).

Cyclocotyla Stapf, Bull Misc. Inform. 1908: 259 (1908).

Cylindropsis Pierre, Bull. Mens. Soc. Linn. Paris, sér. 2, 1: 38 (1898).

Dictyophleba Pierre, Bull. Mens. Soc. Linn. Paris, sér. 2, 1: 92 (1898).

Hancornia Gomes, Mem. Math. Phis. Acad. Real Sci. Lisboa 3: 51 (1812).

Lacmellea $\mathrm{H}$. Karst., Linnaea 28: 449 (1857).

Landolphia P. Beauv., Fl. Oware Bénin 1: 54 (1804), nom. cons.

Leuconotis Jack, Trans. Linn. Soc. 14: 121 (1823).

Orthopichonia H. Huber, Kew Bull. 15: 437 (1962).

Pacouria Aubl., Hist. Pl. Guiane 268, t. 105 (1775).

Parahancornia Ducke, Arch. Jard. Bot. Rio de Janeiro 3: 242 (1922).

Saba (Pichon) Pichon, Mém. Inst. Franç. Afrique Noire 35: 302 (1953).

Vahadenia Stapf in Thiselton-Dyer, Fl. Trop. Africa 4(1): 29 (1902).

Willughbeia Roxb., Pl. Coromandel 3: 77, t. 280 (1819), nom. cons.

\section{d. Tabernaemontaneae G. Don, Gen. Hist. 4:70, 87 (1838)}

Trees or shrubs, rarely lianas, with milky latex. Leaves opposite. Calycine colleters mostly present, often multiseriate; corolla salveriform or rarely funnelform; corolla lobes often inflexed in bud; aestivation almost always sinistrorse; corona mostly absent; anthers with lignified guide rails; style head with stigmatic region beneath basal collar or flange and usually with (often 5-ribbed) upper wreath or style head subglobose and without basal collar and upper wreath and body uniformly receptive; ovary apocarpous or syncarpous; disc adnate, indistinct, or free. Fruit with fleshy pericarp, either an indehiscent berry with the seeds usually embedded in pulp or a pair of dehiscent follicles with arillate seeds; seeds often with deep hilar groove on one side and longitudinal grooves on the other or testa wrinkled or pitted; endocarp not forming a stone; endosperm ruminate. Pollen 3-5-colporate. Secondary chemistry highly evolved indole alkaloids of the heynean type. $\mathrm{n}=11$. Distribution: Old World and New World, tropics.

Ambelania Aubl., Hist. Pl. Guiane 265, t. 104 (1775).

Bonafousia A. DC., Prodr. 8: 359 (1844).

Callichilia Stapf in Thiselton-Dyer, Fl. Trop. Afr. 4(1): 130 (1902).

Calocrater K. Schum. in Engler \& Prantl, Nat. Pflanzenfam. 4(2): 175 (1895)

Carvalhoa K. Schum. in Engler \& Prantl, Nat. Pflanzenfam. 4(2): 189 (1895).

Crioceras Pierre, Bull. Mens. Soc. Linn. Paris 1: 1311 (1897).

Macoubea Aubl., Hist. Pl. Guiane Suppl. 17, t. 378 (1775).

Molongum Pichon, Mém. Mus. Natl. Hist. Nat. 24: 167 (1948).

Mucoa Zarucchi, Agric. Univ. Wageningen Pap. 87(1): 40 (1988).

Neocouma Pierre, Bull. Mens. Soc. Linn. Paris, sér. 2, 1: 33 (1898).

Rhigospira Miers, Apocyn. S. Am. 67, t. 10A (1878).

Schizozygia Baill., Bull. Mens. Soc. Linn. Paris 1: 752 (1888).

Spongiosperma Zarucchi, Agric. Univ. Wageningen Pap. 87(1): 48 (1988).

Stemmadenia Benth., Bot. Voyage Sulphur 124, t. 44 (1845).

Stenosolen (Müll.-Arg.) Markgr. in Pulle, Fl. Suriname 4(1): 455 (1937).

Tabernaemontana L., Sp. Pl. 1: 210 (1753).

Tabernanthe Baill., Bull. Mens. Soc. Linn. Paris 1: 782 (1888).

Voacanga Thouars, Gen. Nov. Madag. 10 (1806).

Woytkowskia Woodson, Ann. Missouri Bot. Gard. 47 : 74 (1960). 


\section{e. Melodineae G. Don, Gen. Hist. 4: 71, 101 (1838)}

Lianas, trees, or shrubs, with milky latex. Leaves opposite or whorled. Calycine colleters usually absent; corolla salveriform; corolla-lobe aestivation sinistrorse; small corolline corona often present in petal sinuses (well developed and often annular in Melodinus); anther connective with a apical extension in Diplorhynchus and Dyera and with both apical connective extension and small sterile basal lobes in Pycnobotrya; style head mostly without basal collar or upper wreath; disc usually absent; ovary apocarpous or syncarpous, sometimes only at base (Diplorhynchus), more than half inferior in Dyera. Fruit mostly a pair of follicles with dry pericarp (fruit a capsule in Craspidospermum and a fleshy berry in Melodinus); endocarp not forming a stone; seeds usually numerous, smooth, flat, and winged, often peltately attached with long funicle (somewhat verrucose, only slightly compressed, and embedded in pulpy placenta in Melodinus). Endosperm mostly smooth. Pollen usually 3-colporate (in tetrads in some Melodinus species and porate tetrads in Craspidospermum). Secondary compounds indole alkaloids. $x=10,11$. Distribution: Old World, tropics, rarely subtropics.

Craspidospermum Bojer ex A. DC., Prodr. 8: 323 (1844).

Diplorhynchus Welw. ex Ficalho \& Hiern, Trans. Linn. Soc. London, Bot. ser. 2, 2: 22, t. 5 (1881).

Dyera Hook. f., J. Linn. Soc. Bot. 19: 293 (1882).

Gonioma E. Mey., Comment. Pl. Africae Austr. 188 (1838).

Kamettia Kostel., Allg. Med. Pharm. Fl. 3: 1062 (1834).

Melodinus J. R. \& G. Forster, Charact. Gen. 37, t. 19 (1776).

Pycnobotrya Benth. in Benth. \& Hook. f., Gen. 2: 715 (1876).

Stephanostegia Baill., Bull. Mens. Soc. Linn. Paris 1: 748 (1888).

\section{f. Hunterieae Miers, Apocyn. S. Amer. 6 (1878)}

Trees or shrubs, with milky latex. Leaves opposite. Calycine colleters mostly present, often multiseriate, rarely absent; corolla salveriform; corolla-lobe aestivation sinistrorse; corona absent; style head uniformly receptive, ovoid to narrowly clavate, with neither basal collar nor upper wreath but often with slender, elongate nonreceptive apices; ovary apocarpous, 2-5-carpellate; disc adnate or indistinct. Fruit a composite berry of 2-5 distinct mericarps with fleshy, fibrous pericarp; endocarp not forming a stone; seeds ovoid, embedded in pulp; endosperm smooth. Pollen 3-colporate. Secondary chemistry indole alkaloids. $n=11$. Distribution: Old World, tropics.

Hunteria Roxb., Fl. Indica. 2: 531 (1824).

Picralima Pierre, Bull. Mens. Soc. Linn. Paris 2: 1278 (1896).

Pleiocarpa Benth. in Benth. \& Hook. f., Gen. 2: 699 (1876).

\section{g. Plumerieae E. Mey., Comm. Pl. Afr. Austr. 2: 188 (1838)}

Trees or shrubs, the latter sometimes scrambling, with milky latex; leaves usually alternate, sometimes opposite (whorled in Allamanda). Calycine colleters absent or present; corolla salveriform or funnelform; corolla-lobe aestivation sinistrorse; corolline corona often present below the petal sinuses behind stamen (usually much dissected in Allamanda) and infrastaminal appendages generally present; anther connective often broadened and with elongate apical extension; style head mostly with basal collar or lobes (no distinct basal collar in Plumeria, Himatanthus, or Mortoniella), mostly without upper wreath (well-developed upper wreath present in Allamanda) but often with free apices conspicuously enlarged; ovary apo- 
carpous or syncarpous at the very base (postgenitally syncarpous in Allamanda), hemiinferior in Plumeria, Himatanthus, and Mortoniella; disc absent or present. Fruit mostly a dehiscent pair of follicles (a capsule in Allamanda) or indehiscent and drupaceous (samaroid in Cerberiopsis) with fleshy or dry pericarp; plancentas often lignified in fruit; endocarp sometimes forming a stone; seeds 1-4(-many) per carpel, usually with compressed, winglike margin or distinct papery wing. Endosperm smooth, mostly thin. Pollen 3-colporate. Secondary compounds cardenolides or iridoid glycosides (in Skytanthus, Skytanthus alkaloids). $\mathrm{x}=9$, 10. Distribution: Old World and New World, tropics and subtropics.

Allamanda L., Mant. 146, 214 (1771).

Anechites Griseb., F1. Brit. W. Indian Is1. 410 (1861).

Cameraria L., Sp. P1. 1: 210 (1753).

Cerbera L., Sp. Pl. 1: 208 (1753).

Cerberiopsis Viell. ex Pancher \& Sébert in Sébert, Not. Bois. Nouv. Caledonie 187 (1874).

Himatanthus Willd. ex Schult. in Roem. \& Schult., Syst. Veg. 5: 221 (1819).

Mortoniella Woodson, Ann. Missouri Bot. Gard. 26: 257 (1939).

Plumeria L., Sp. Pl. 1: 209 (1753).

Skytanthus Meyen, Reise 1: 376 (1834).

Thevetia L., Opera Varia 212 (1758), nom. cons.

h. Carisseae Dumort., Anal. Fam. Pl. 26 (1829)

Shrubs with (often branched) spines in leaf axils, with milky latex. Leaves opposite; calycine colleters present or absent; corolla salveriform; corona absent; corolla-lobe aestivation sinistrorse or dextrorse; style head scarcely differentiated, without basal collar, body uniformly receptive; ovary congenitally syncarpous; disc mostly absent or adnate to ovary. Fruit indehiscent, a berry with fleshy, nonfibrous pericarp; endocarp not forming a stone, but placentas becoming lignified in fruit forming woody partition; seeds 2-6(-12), rarely more, compressed; endosperm smooth. Pollen 3-colporate. Secondary chemistry cardenolides. $x=$ 11. Distribution: Old World, tropics and subtropics.

Acokanthera G. Don, Gen. Hist. 4(2): 485 (1838).

Carissa L., Mant. 52 (1767), nom. cons.

\section{i. Alyxieae G. Don, Gen. Syst. 4: 70, 96 (1838)}

Trees, shrubs, or vines, with milky latex. Leaves alternate, opposite, or whorled. Calycine colleters absent; corolla salveriform (sometimes throat somewhat expanded in Condylocarpon); corolla lobes often deeply inflexed in bud; aestivation sinistrorse; corona absent; style head with neither basal collar nor upper wreath, body uniformly receptive; ovary apocarpous or syncarpous (Lepiniopsis and Chilocarpus); in Plectaneia carpels free except for narrow, congenitally fused region in the center of their ventral flanks) and up to 5-carpellate in Lepinia and Lepiniopsis often stipitate; disc absent, indistinct, or adnate. Fruit mostly indehiscent, with fleshy pericarp and endocarp usually forming a stone (pericarp dry in Condylocarpon and Chilocarpus dehiscent; fruit capsular, dry, and dehiscent in Plectaneia); seeds normally not compressed, usually elongate, globular, or ovoid, longitudinally rolled with deep hilar furrow and ruminate endosperm (compressed and with wing in Plectaneia, arillate in Chilocarpus). Pollen 2-3-porate, typically barrel shaped (in tetrads and inaperturate in Condylocarpon). Neither alkaloids nor cardenolides are known to occur in the tribe. $x=9$ (known only for Alyxia). Distribution: Pacific Basin and Asia; Condylocarpon in the New World, tropics. 
Alyxia Banks ex R. Br., Prodr. 469 (1810), nom. cons.

Chilocarpus Blume, Cat. Buitenzorg 22 (1823).

Condylocarpon Desf., Mém. Mus. Hist. Nat. 8: $119(1822)$.

Lepinia Decne., Ann. Sci. Nat., Bot., sér. 3, 12: 194, t. 9 (1849).

Lepiniopsis Valeton, Ann. Jard. Bot. Buitenzorg 12: 251 (1895).

Plectaneia Thouars, Gen. Nov. Madag. 11 (1806).

Pteralyxia K. Schum. in Engler \& Prantl, Nat. Pflanzenfam. 4(2): 151 (1895).

\section{Apocynoideae Burnett, Outlines Bot. 1012, 1095, 1104 (1835)}

Woody lianas, vines, less frequently trees or shrubs, rarely perennial herbs. Latex usually milky (often clear in Echiteae and some Wrightieae). Leaves almost always opposite, sometimes with adaxial cluster of colleters at juncture of petiole apex and blade base (some Mesechiteae and Apocyneae) or domatia abaxially in axils of secondary veins with midvein (some Malouetieae, Mesechiteae, and Apocyneae). Calycine colleters normally present; corolla infundibuliform, tubular campanulate, salveriform, urceolate, tubular, or rotate; corolla lobes sometimes inflexed in bud; aestivation almost always dextrorse (sinistrorse in some Wrightieae and in Parameria); corolline corona often present, sometimes annular, often petaloid or dissected (Wrightieae), sometimes lower down in corolla tube behind stamen (Apocyneae, Echiteae), sometimes more than one kind of corona present (mainly Echiteae); rarely corona lobes on dorsal side of anther (some Malouetieae, Apocyneae); anthers included or exserted, almost always fertile only in upper part, lower part enlarged and sterile and sides elaborated into lignified guide rails (guide rails poorly developed in some Malouetieae), attached to style head (only very weakly so in some Malouetieae and Wrightieae). Style head variously shaped, epidermis sometimes radially differentiated into 5 secretory and nonsecretory zones, sometimes with collar at base and crest at the apex; stigmatic region on lower cylindrical part on underside; ovary usually apocarpous, sometimes postgenitally syncarpous; ovules mostly numerous per carpel. Nectaries usually present in ring around base of ovary, sometimes coalesced into annulus (absent in most Wrightieae). Fruit usually a pair of slender to stout, thinly to thickly woody, ventrally dehiscent follicles with dry pericarp; endocarp not forming a stone; seeds usually numerous, compressed, with coma usually on micropylar end, sometimes with a coma at the chalazal end or at both micropylar and chalazal ends (some Wrightieae and Malouetieae), rarely ecomose (some Malouetieae); endosperm thin, not ruminate. Pollen porate, most commonly with 3-4 apertures; occasionally grains 2-5aperturate or polypantoporate. Steroidal alkaloids or cardenolides often present, indole alkaloids absent.

Key to the tribes of the Apocynoideae

1. Style head spool shaped, slender in middle, greatest in diameter at base; membranous collar usually present at base; disc absent or present.

1. Style head globose with slender, elongate, conical apex or broadly ovoid to broadly fusiform, broadest at about middle and tapering at both ends or style head cylindrical with 5 vertical ribs; membranous collar absent at base; disc almost always present . . . . . . 3

2. Thecae not agglutinated to style head; anthers weakly attached to style head at one level; flat, petaloid corona segments mostly present in petal sinuses; disc almost always absent; trees, rarely lianas . . . . . . . . . . . . . . . Wrightieae

2. Thecae agglutinated to style head; anthers strongly attached to style head at two levels; corona, if present, in form of thickened annulus in mouth or thick, fingerlike segments below level of petal sinuses; disc present; almost always lianas. . . . . . . Echiteae 
3. Style head globose with slender elongate conical apex, more or less round in cross section; anthers attached (sometimes only very weakly so) at about middle of style head; thecae free; chalazal coma often present; mostly trees, sometimes lianas. . . . . . . . . . . . . . . . . . . Malouetieae

3. Style head broadly ovoid to very broadly fusiform or cylindrical with 5 prominent ridges, often pentagonal or starlike in cross section; anthers usually attached at about middle of style head or along length of vertical ridges; thecae mostly agglutinated; chalazal coma absent; lianas, vines, or perennial herbs . . . . . . . . . 4 4. Style head broadly ovoid to very broadly fusiform; stamens generally inserted near base of the corolla; ovary often semi-inferior; anthers attached to style head by slender tuft of hairs, with broader sweeping brush of hairs below

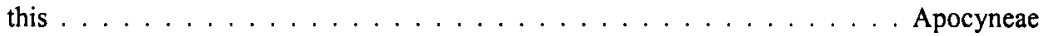

4. Style head with 5 strongly projecting ribs, at least at base; stamens mostly inserted in corolla throat; ovary superior; anthers attached to style-head ribs by very short hairs or cellular fusion

Mesechiteae

\section{a. Wrightieae G. Don, Gen. Syst. 4: 70, 85 (1838)}

Shrubs, trees, or woody climbers. Latex usually milky, sometimes clear. Leaves opposite (alternate in Adenium, whorled in Nerium). Calycine colleters few, alternisepalous, or more numerous. Corolla salveriform to infundibuliform or rarely tubular campanulate; aestivation sinistrorse in Wrightia, Pleioceras, and Stephanostemma; often with conspicuous corona of flat, petaloid segments in mouth. Stamens included to exserted; lignified guide rails often relatively short. Anthers often only weakly attached to base of style head. Style head usually with basal collar and upper wreath of longer hairs; pollen shed onto upper hair wreath; stigma located beneath basal collar. Disc almost always absent. Ovary apocarpous or, more rarely, syncarpous (secondarily syncarpous in Nerium). Follicles often rather stout, sometimes long and slender, rarely a postgenitally fused capsule (Nerium and some spp. of Wrightia); seeds with a chalazal and/or micropylar coma. Pollen 3-4-porate. Secondary compounds cardenolides. $\mathrm{x}=10,11$. Distribution: Old World, tropics, rarely subtropics (Nerium temperate).

Adenium Roem. \& Schult., Syst. Veg. 4: 35 (1819).

Isonema $\mathrm{R}$. Br., Asclepiadeae 52 (1810).

Nerium L., Sp. Pl. 1: 209 (1753).

Pleioceras Baill., Bull. Mens. Soc. Linn., Paris 1: 759 (1888).

Stephanostema K. Schum., Bot. Jahrb. Syst. 34: 325 (1904).

Strophanthus DC., Bull. Sci. Soc. Philom. Paris 3: 122 (1802).

Wrightia R. Br., Prodr. 467 (1810).

\section{b. Malouetieae Müll.-Arg., in Mart., Fl. Brasil. 6(1): 6(1860)}

Shrubs, trees, or woody climbers. Latex usually milky. Leaves opposite (alternate in Pachypodium), often with domatia abaxially in axils of secondary veins with midvein. Calycine colleters usually few, alternisepalous, sometimes several and evenly spread across base of sepal. Corolla salveriform to tubular campanulate; aestivation dextrorse; corona usually absent, but well developed in Malouetia and as inflated hump on dorsal side of anther in Kibatalia. Stamens included or exserted; lignified guide rails usually well developed (absent in Holarrhena). Anthers attached to middle of style head. Style head globose with narrowly conical upper part or broadly fusiform, usually without basal collar and upper wreath; stigmatic region on sides of lower cylindrical part below adnation of anthers; pollen shed onto sides of 
upper cone; ovary apocarpous; ovules mostly numerous per carpel; nectary disc usually well developed. Follicles mostly long and slender, sometimes stouter; seeds with chalazal and/or micropylar coma, ecomose, or entire seed testa with long hairs. Pollen quite variable: mostly 3-4-porate, but (1-)2(-4) in Mascarenhasia and Pachypodium, 2-4-porate in Malouetia and polypantoporate in Spirolobium. Secondary compounds steroids. $\mathrm{x}=11$ (9 in Pachypodium). Distribution: Old World (Malouetia also in Central America and South America), tropics.

Alafia Thouars, Gen. Nov. Madag. 11 (1806).

Allowoodsonia Markgr., Gard. Bull. Straits Settlem. 22: 23 (1967).

Carruthersia Seem., Fl. Vitiensis 155 (1866).

Farquharia Stapf, Bull. Misc. Inform. 1912: 278 (1912).

Funtumia Stapf, Proc. Linn. Soc. 1899: 2 (1899).

Holarrhena R. Br., Asclepiadeae 51 (1810).

Kibatalia G. Don, Gen. Hist. 4(1): 86 (1837).

Malouetia A. DC., Prodr. 8: 378 (1844).

Malouetiella Pichon, Bull. Jard. Bot. Etat 22: 131 (1952).

Mascarenhasia A. DC., Prodr. 8: 487 (1844).

Pachypodium Lindl., Edwards' Bot. Reg. 16: t. 1321 (1830).

Spirolobium Baill,, Bull. Mens. Soc. Linn. Paris 1: 773 (1889), nom. cons.

\section{c. Apocyneae Rchb., Fl. Germ. Excurs. 1(3): 410, 429 (1831)}

Woody climbers, rarely perennial herbs. Latex usually milky. Leaves opposite, rarely whorled or alternate, sometimes with domatia abaxially in axils of secondary veins with midvein and/or cluster of colleters adaxially at juncture of apex of petiole and base of blade. Calycine colleters few and alternisepalous or numerous and spread across base of sepal inside (rarely absent); corolla salveriform, campanulate, or urceolate; corolla-lobe aestivation dextrorse (sinistrorse in Parameria), rarely valvate; corona, if present, mostly as small pouches in petal sinuses, sometimes lower down on corolla tube behind stamens (Apocynum with alternistaminal appendages near base of corolla tube). Stamens usually inserted near the base of the corolla tube, rarely inserted on thickened staminal feet (e.g., Motandra, Aganosma); lignified guide rails long, well developed; main attachment at about middle of style head; base of thecae normally agglutinated to upper style head as well; style head broadly fusiform, broadest and often with equatorial flange at about middle, normally with neither basal collar nor upper wreath; stigmatic region usually on lower cylindrical region below adnation of anthers. Disc present; ovary apocarpous, postgenitally syncarpous in Beaumontia and Parepigynum, often semi-inferior. Follicles generally thin walled (a stout capsule in secondarily syncarpous species); seeds flat, linear to ellipsoid or ovate, the testa glabrous or hairy with micropylar (sometimes rostrate) coma. Pollen (2-)3(-4)-porate (polypantoporate in Trachelospermum, Vallariopsis, and Apocynum). Secondary compounds cardenolides or steroidal alkaloids (Elytropus). $\mathrm{x}=10,11$ (more rarely 8, 12). Distribution: Old World, tropics (Odontadenia exclusively New World and Apocynum and one sp. of Trachelospermum also New World and there temperate to subtropical).

Aganonerion Pierre ex Spire, Contr. Apoc. 43 (1905).

Aganosma (Blume) G. Don, Gen. Hist. 4(1): 77 (1837).

Anodendron A. DC., Prodr. 8: 443 (1844).

Apocynum L., Sp. Pl. 1: 213 (1753).

Baharuia Middleton, Blumea 40: 445 (1995).

Baissea A. DC., Prodr. 8: 424 (1844).

Beaumontia Wall., Tent. Fl. Napal. 14 (1824).

Chonemorpha G. Don, Gen. Hist. 4(1): 76 (1837), nom. cons. 
Cleghornia Wight, Icon. 4(2): 5, t. 3310 (1848).

Dewevrella De Wild., Mission Laurent 1: 548, 2: t. 414, 415 (1907).

Elytropus Müll.-Arg., Bot. Zeitung (Berlin) 18: 21 (1860).

Epigynum Wight, Icon. 4(2): 4 (1848).

Eucorymbia Stapf, Hook. Icon. P1. 28: t. 2764 (1903).

Forsteronia G. Mey., Prim. Fl. Esseq. 133 (1818).

Ichnocarpus R. Br., Asclepiadeae 50 (1810), nom. cons.

Ixodonerium Pit., in Lecomte, Fl. Gén. Indo-Chine 3: 1228 (1933).

Motandra A. DC., Prodr. 8: 423 (1844).

Odontadenia Benth., J. Bot. (Hooker) 3: 242 (1841).

Oncinotis Benth. in Hook., Niger Fl. 451 (1849).

Papuechites Markgr., Nova Guinea 14: 287 (1927).

Parameria Benth. in Benth. \& Hook. f., Gen. 2: 715 (1876).

Parepigynum Tsiang \& P. T. Li, Acta Phytotax. Sin. 11: 394 (1973).

Sindechites Oliv., Hook. Icon. Pl. 18: t. 1772 (1888).

Trachelospermum Lem., Jard. Fleur. 1: t. 61 (1851), com. cons. prop.

Urceola Roxb., Asiat. Res. 5: 169 (1799), nom. cons.

Vallariopsis Woodson, Philipp. J. Sci. 60: 288 (1936).

Vallaris Burm. f., Fl. Indica 51 (1768).

\section{d. Mesechiteae Miers, Apocyn. S. Amer. 10 (1878)}

Vines, woody lianas, or perennial herbs, the latter sometimes with xylopod. Latex usually milky. Leaves opposite, rarely whorled, often with cluster of colleters adaxially at base of blade (distributed along the length of midrib in some species of Mandevilla), sometimes with domatia abaxially in axils of secondary veins with the midvein. Calycine colleters mostly in alternisepalous groups or in continuous ring, more rarely solitary and episepalous; corolla usually divided into narrow lower tube and expanded upper throat, mostly infundibuliform or tubular campanulate, more rarely tubular or salveriform; corolla-lobe aestivation dextrorse; distinct corona usually absent; stamens mostly inserted at base of throat; lignified guide rails long, well developed; style head with neither basal collar nor upper wreath, with 5 arms, which usually project from lower part (arms forming long ridges for most of length of style head in Mandevilla and Macrosiphonia) to which anthers are attached; stigmatic zone confined to region on underside or lower region of style head. Disc present; ovary apocarpous. Follicles usually slender; seeds linear, testa glabrous, with micropylar coma. Pollen (2-)3-5(-6)-porate. No information on secondary compounds or chromosome numbers was found in the literature. Distribution: New World, tropics and subtropics.

Allomarkgrafia Woodson, Ann. Missouri Bot. Gard. 19: 45 (1932).

Galactophora Woodson, Ann. Missouri Bot. Gard. 19: 49 (1932).

Macrosiphonia Müll.-Arg. in Mart., Fl. Brasil. 6(1): 137 (1860).

Mandevilla Lindl., Edwards' Bot. Reg. 3: t. 7 (1840).

Mesechites Müll.-Arg. in Mart., Fl. Brasil. 6(1): 150 (1860).

Quiotania Zarucchi, Novon 1: 33 (1991).

Secondatia A. DC., Prodr. 8: 445 (1844).

Telosiphonia (Woodson) Henrickson, Aliso 14: 184 (1996).

Tintinnabularia Woodson, Ann. Missouri Bot. Gard. 23: 387, t. 7 (1936).

\section{e. Echiteae Bartl., Ord. Nat. Pl. 204 (1830)}

Vines or woody lianas, rarely erect shrubs. Latex often clear, sometimes milky. Leaves opposite, rarely whorled. Calycine colleters often one, episepalous, or several and spread across 
base of sepal, rarely absent; corolla salveriform, infundibuliform, tubular campanulate, campanulate (rotate in Parsonsia, Artia, Ecua, and Thernardia); corolla-lobe aestivation dextrorse, rarely valvate; stamens mostly inserted in upper part of corolla tube (near base in Parsonsia, Artia, Ecua, Pottsia, and Thernardia); anthers often partially to almost completely exserted, with large, lignified guide rails, attached near base of style head; style head cylindrical to narrowly fusiform, broadest and with (usually well developed, often membranous) collar at base and sometimes upper wreath as well; stigmatic zone located on underside of style head beneath collar. Disc present; ovary apocarpous (postgenitally syncarpous in Parsonsia, Artia, Thernardia, Temnadenia, and some spp. of Prestonia). Follicles typically slender (postgenitally fused in Parsonsia, Artia, Thernardia, Temnadenia, and some spp. of Prestonia, but splitting apart at maturity along suture); seeds mostly linear but broadly ovate in Parsonsia and Artia, testa glabrous, with micropylar (often rostrate) coma. Pollen 3-5(-8)porate. $x=6,7,8,9$. Secondary compounds cardenolides (known only for Pentalinon). Distribution: New World and Old World, tropics.

Amalocalyx Pierre, Bull. Mens. Soc. Linn. Paris, sér. 2, 1: 28 (1898).

Angadenia Miers, Apocyn. South Amer. 173 (1878).

Artia Guillaumin, Bull. Soc. Bot. France 88: 380 (1941).

Asketanthera Woodson, Ann. Missouri Bot. Gard. 19: 46 (1932).

Cycladenia Benth., Pl. Hartw. 322 (1849).

Echites P. Browne, Civ. Nat. Hist. Jamaica 182 (1756).

Ecua Middleton, Blumea 41: 33 (1996).

Fernaldia Woodson, Ann. Missouri Bot. Gard. 19: 48 (1932).

Hylaea F. J. Morales, Novon (1999).

Laubertia A. DC., Prodr. 8: 486 (1844).

Macropharynx Rusby, Mem. New York Bot. Gard. 7: 327, t. 6 (1927).

Neobracea Britton, in Britton \& Millsp. Bahama Fl. 335 (1920).

Parsonsia R. Br., Prodr. 465 (1810), nom. cons.

Peltastes Woodson, Ann. Missouri Bot. Gard. 19: 375 (1932).

Pentalinon Voigt, Hortus Suburb. Calcut. 523 (1845).

Pottsia Hook. \& Arn., Bot. Beechey's Voyage 198 (1837).

Prestonia R. Br., Asclepiadeae 58 (1810), nom. cons.

Rhabdadenia Müll.-Arg. in Mart., Fl. Brasil. 6(1): 173 (1860).

Salpinctes Woodson, Bull. Torrey Bot. Club 58: 453 (1931).

Stipecoma Müll.-Arg. in Mart., Fl. Brasil. 6(1): 175 (1860).

Temnadenia Miers, Apocyn. South Amer. 207 (1878).

Thenardia Kunth, Nov. Gen. 3: 209 (1819).

\section{Periplocoideae R. Br. ex Endl., Gen. Pl. 2: 587 (1838)}

Perennials, woody sometimes tuberous lianas, shrubs to small trees (Utleria), erect scrambling or twining herbs or geophytes with underground tuber. Latex milky (clear in Raphionacme namibiana). Leaves opposite, sometimes with cluster of colleters adaxially at juncture of apex of petiole and base of blade. Calyx with usually few adaxial alternisepalous colleters. Corolla rotate to tube rarely longer than lobes; lobes usually spreading, with valvate to dextrorsely imbricate aestivation; corolline corona usually present in sinuses of petals as pair of lobules or single filiform to clavate lobule (usually faintly bifid), often much reduced to rounded bumps or absent (Baroniella, Baseonema, Pentanura). Stamens inserted between base of corolla lobes and base of tube on apex of thickened, ridgelike staminal foot running down corolla tube and mostly fusing at base into solid ring around narrow neck in style above ovaries, apex of foot also sometimes with corona lobe behind point of insertion of filament, 
this corona lobe sometimes confluent with corolline corona lobes and even more or less in series with them; filaments usually inclined toward style head, usually more or less cylindrical; anthers usually exposed, 4-locular, much broader than filament, usually more or less deltoid, nearly horizontal to ascending, with membranous margins neither lignified nor fashioned into guide rails, often laterally adherent or postgenitally fused into more or less umbrellalike structure over style head, adaxially fused to style head usually above its thickest portion (rarely below: Hemidesmus); inner and outer coronal series on stamens lacking. Nectaries on sides of staminal feet or in 5 troughs between staminal feet bearing stamens. Pollen usually shed as Tshaped to rhomboidal tetrads, sometimes gathered into more or less horizontally oriented pollinia (two per locule) not surrounded by waxy outer wall (Atherolepis, Decalepis, Finlaysonia, Gongylosperma, Gymnanthera, Hemidesmus, Meladerma, Streptocaulon, and Utleria); grains porate, with few to many pores, these scattered or pairwise at the juncture of the monads. Style head broad and flat topped to tapering from broad base into narrow, often bifid apex, with thick and short to long and slender neck joining it to ovaries and 5 stigmatic zones near lower edge between anthers, with 5 vertically oriented grooves between anthers in which translator secreted; translator consisting of spoon- to cornet-shaped receptacle above (into which pollen/pollinia deposited), with small sticky viscidium at lower end projecting vertically over edge of style head or horizontally beneath it; ovary apocarpous, semi-inferior, rarely superior (Gymnanthera). Fruit a pair of slender to sometimes very swollen, fusiform, ventrally dehiscent follicles (sometimes one by abortion: Raphionacme) with dry pericarp; seeds numerous, compressed, usually narrowly elliptical in outline, without winglike margin, with micropylar coma (extended around entire margin in Finlaysonia and Raphionacme namibiana), endosperm thin. $\mathrm{x}=11$. Secondary compounds typically cardenolides. Distribution: Old World, dry temperate, subtropics, tropics.

Atherandra Decne. in A. DC., Prodr. 8: 497 (1844).

Atherolepis Hook. f. in Hook. Icon. PI. 15: 26, t. 1433 (1883).

Baroniella Costantin \& Gallaud, Ann. Sci. Nat. Bot., ser. 9, 6: 354 (1907).

Baseonema Schltr. \& Rendle, J. Bot. 34: 97 (1896).

Buckollia Venter \& R. L. Verh., S. Afr. J. Bot. 60: 97 (1994).

Camptocarpus Decne. in A. DC., Prodr. 8: 493 (1844) (nom. cons.).

Cryptolepis R. Br., Asclepiadeae 58 (1810).

Cryptosiegia R. Br., Bot. Reg. 5: t. 435 (1820).

Decalepis Wight \& Arn. in Wight, Contr. Bot. India 64 (1834).

Ectadium E. Mey., Comment PI. Africae Austr. 188 (1838).

Epistemma D. V. Field \& J. B. Hall, Kew Bull. 37: 117 (1982).

Finlaysonia Wall., Pl. Asiat. Rar. 2: 48, t. 162 (1831).

Gongylosperma King \& Gamble, J. Asiat. Soc. Bengal, pt. 2, Nat. Hist. 74: 510 (1908).

Gymnanthera R. Br., Prodr. 464 (1810).

Hemidesmus R. Br., Asclepiadeae 45 (1810).

Ischnolepis Jum. \& H. Perrier, Rev. Gén. Bot. 21: 53 (1909).

Maclaudia Venter \& R. L. Verh., Bot. J. Linn. Soc. 115: 58 (1994).

Mangenotia Pichon, Bull. Soc. Bot. France 101: 246 (1954).

Meladerma Kerr, Bull. Misc. Inform. 1938: 445 (1938).

Mondia Skeels in U.S.D.A. Bur. Pl. Industr. Bull. 223: 45 (1911).

Myriopteron Griff., Calcutta J. Nat. Hist. 4: 385 (1844).

Omphalogonus Baill., Bull. Mens. Soc. Linn. Paris 2: 812 (1889).

Pentanura Blume, Mus. Bot. 1: 125 (1850).

Pentopetia Decne. in A. DC., Prodr. 8: 500 (1844).

Periploca L., Sp. Pl. 1: 211 (1753).

Petopentia Bullock, Kew Bull. 1954: 362 (1954). 
Phyllanthera Blume, Bijdr. 1048 (1826-1827).

Raphionacme Harv., London J. Bot. 1: 22 (1842)

Sacleuxia Baill., Hist. Pl. 10: 265 (1890).

Sarcorrhiza Bullock, Hook. Icon. P1. 36: t. 3585 (1962).

Schlechterella K. Schum. in Engler \& Prantl, Nat. Pflanzenfam. Index 2-4: 462 (1899).

Stelmacrypton Baill., Bull. Mens. Soc. Linn. Paris 2: 812 (1889).

Stomatostemma N. E. Br. in Thiselton-Dyer, Fl. Trop. Afr. 4(1): 252 (1902).

Streptocaulon Wight \& Arn. in Wight, Contr. Bot. India 64 (1834).

Streptomanes K. Schum. in Schumann \& Lauterbach, Nachtr. Fl. Deutsch. Südsee, 352 (1905).

Tacazzea Decne. in A. DC., Prodr. 8: 492 (1844).

Telectadium Baill., Bull. Mens. Soc. Linn. Paris 2: 801 (1889).

Utleria Bedd. ex Benth. in Benth. \& Hook. f., Gen. 2: 743 (1876).

Zacateza Bullock, Kew Bull. 1954: 361 (1954).

Zygostelma Benth. in Benth. \& Hook. f., Gen. 2: 740 (1876).

\section{Secamonoideae Endl., Gen. Pl. 2: 589 (1838)}

Large lianas to twining perennial herbs or small erect shrubs. Latex milky. Leaves opposite, sometimes with few colleters clustered adaxially at juncture of apex of petiole and base of blade. Calyx usually with few adaxial, alternisepalous colleters. Corolla rotate to campanulate or urceolate; lobes mostly with dextrorsely contorted or valvate aestivation (but sinistrorsely contorted in Genianthus); corolline corona consisting of 5 fleshy ridges radiating out along inner surface of corolla lobes close to and nearly parallel to margins and meeting in sinuses where they sometimes form pouch. Stamens inserted on staminal tube around ovaries and adaxially fused to sides of style head (usually in its cylindrical portion); anthers 4-locular, sessile on apex of staminal tube, sometimes partly hidden by corona lobes, usually more or less deltoid, erect to more or less horizontal, rarely with elongated appendages (Calyptranthera), lateral margins, often covered with hairs or with marginal cilia, with well-developed, lignified guide rails below fertile part; staminal tube with simple to complex corona attached dorsally (rarely absent) and without clear vascularization: outer corona rarely present as small, continuous ridge running beneath guide rail and below anthers; inner corona arising at or slightly below base of anthers, sometimes consisting of two series of lobes (Genianthus). Nectaries consisting of 5 vertical alternistaminal troughs behind guide rails on staminal tube. Pollen inaperturate, gathered into minute pollinia, two per locule, not surrounded by waxy outer wall; pollinia more or less erect, forming above guide rails, more or less ellipsoidal, without insertion crest, sometimes adjacent pairs adhering to form single body. Style head very variably shaped, with thick cylindrical part just above ovaries widening slightly toward apex, narrowing above this into usually bifid apex, which is sometimes much inflated, occasionally long and slender, with 5 stigmatic zones located on sides of lower cylindrical part, probably just below thickest area behind guide rails, secreting translator just above each guide rail; translator consisting of small, porous, cliplike, brownish corpuscle with flanks and sometimes with floor, sometimes with one or two caudicles (if two then each attaching a pair of pollinia to corpuscle) (Genianthus, Secamonopsis, and some species of Secamone); ovary apocarpous, semi-inferior. Fruit a pair of slender to stout, fusiform, ventrally dehiscent follicles with dry pericarp; seeds numerous, compressed, more or less elliptical in outline, without winglike margin, with micropylar coma, endosperm thin. No information on chromosome numbers found in literature. Secondary compounds (reported only for Menabea $=$ Pervillea ) are cardenolides. Distribution: Old World, temperate to tropics.

Calyptranthera Klack., Novon 6: 27 (1996).

Genianthus Hook. f., Fl. Brit. India 4: 15 (1883). 
Goniostemma Wight, Contr. Bot. India 62 (1834).

Pervillea Decne. in A. DC., Prodr. 8: 613 (1844).

Rhynchostigma Benth. in Hook. Icon. PI. 12: 77, t. 1189 (1876).

Secamone R. Br., Prodr. 464 (1810).

Secamonopsis Jum., Compt. Rend. Hebd. Séances Acad. Sci. 147: 689 (1908).

Toxocarpus Wight \& Arn. in Wight, Contr. Bot. India 61 (1834).

Trichosandra Decne. in A. DC. Prodr. 8: 625 (1844).

\section{Asclepiadoideae R. Br. ex Burnett, Outlines Bot. 1012, 1095, 1103 (1835)}

Trees to shrubs or herbs, succulents, or small geophytes (rarely annual), with milky or clear latex. Leaves opposite (rarely whorled), sometimes reduced to small rudiment or occasionally a spine, often with cluster of colleters adaxially at juncture of apex of petiole and base of blade. Calyx usually with few to many adaxial, more or less alternisepalous colleters. Corolla rotate to tubular; lobes valvate to imbricate; corolline corona rare in sinuses of lobes (except in some Ceropegieae and Gonolobinae, where present as annulus). Stamens inserted on staminal tube around ovaries and adaxially fused to style head below its thickest portion near its base; anthers 2-locular, sessile on apex of staminal tube, spreading, erect, or horizontal (rarely descending), deltoid, subquadrate, with or without sterile, membranous, apical appendage, lateral margins sometimes becoming membranous after dehiscence, with welldeveloped, lignified guide rails alongside or below fertile part; staminal tube with simple to complex corona attached dorsally (rarely absent) and without clear vascularization: outer corona frequently present at or near base, of 5 free lobes to fused into tube; inner corona usually present at or just below bases of anthers at apex of staminal tube, usually of 5 free lobes. Nectaries consisting of 5 vertical alternistaminal troughs behind guide rails on staminal tube. Pollen gathered into pollinia, one per locule, with waxy outer wall, often with hyaline insertion crest. Style head broad, often with flat or concave apex (rarely conical to slenderly conical), sessile on top of ovaries to tapering gradually with narrow neck into them, with 5 stigmatic zones located on sides of lower cylindrical part behind guide rails, secreting translator just above each guide rail; translator consisting of hard, cliplike, brown to black corpuscle, mostly with flanks and floor, with two flexible, translucent caudicles (rarely absent in some Marsdenieae), each of which attaches one pollinium to corpuscle; ovary apocarpous, mostly superior. Fruit a pair (often one by abortion) of slender to stout fusiform, more or less obclavate (rarely very stout to more or less spherical), ventrally dehiscent follicles with dry pericarp; seeds numerous, compressed, more or less elliptical in outline, often with winglike margin, mostly with micropylar coma (rarely absent or present around seed margin), endosperm thin. $x=11$ (rarely 10,9). Distribution: cosmopolitan, temperate to tropics.

Key to the tribes of the Asclepiadoideae

1. Pollinium developing in part of anther below position of corpuscle . . . . . . . Asclepiadeae

1. Pollinium developing in part of anther above position of corpuscle . . . . . . . . . 2

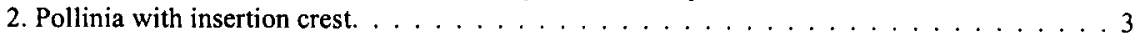

2. Pollinia without insertion crest $\ldots \ldots \ldots \ldots \ldots \ldots \ldots$

3. Insertion crest on inner or lower edge of pollinium; coronal elements absent beneath guide rails . . . . . . . . . . . . . . . . Marsdenieae

3. Insertion crest on upper or outer edge of pollinium; coronal elements present beneath guide rails. . . . . . . . . . . . . . . . Ceropegieae 4. Ovaries narrowing gradually into slender neck below style head; anther appendages with basal horizontal slit. Asclepiadeae 
4. Style head sessile on ovaries that lack slender neck; anther appendages without basal horizontal slit . . . . . . . . . . . . . . . Marsdenieae

Note: In this key and in the descriptions below, the parts of the pollinium (e.g., inner side, outer side) are labeled relative to the anther in which the pollinium has arisen.

\section{a. Marsdenieae Benth., Fl. Austral. 4: 325, 333 (1868)}

Herbs, vines, lithophytes, or epiphytes (these usually leaf succulents), rarely stem succulents, with milky, yellow, or clear latex. Corolla rotate to urceolate; lobes with valvate to dextrorsely imbricate aestivation; corolline corona rare (e.g., Sarcolobus, Marsdenia), consisting of ridges near sinuses of petals running down corolla tube to near base. Anthers erect to more or less horizontal, often with apical appendage, but this never constricted at base, with guide rails below fertile part (more or less poorly developed in Fockea). Outer corona near base of staminal tube, rarely ringlike or cupular around whole column (Gunnessia), mostly absent; inner corona usually of 5 free small to large entire lobes, rarely absent (Rhyssolobium). Pollinia erect to horizontal, mostly more or less ellipsoidal, occasionally with hyaline insertion crest along inner or lower edge (Micholitzia) through which pollen tubes emerge. Style head broad, with thick convex to conical apex, sessile on top of ovaries; corpuscle usually with flanks and floor (occasionally very fragile and lacking floor: Cibirhiza, Fockea, Gongronema); caudicles normally present (more or less absent in Cibirhiza, Fockea). Follicles (often only one by abortion) slender to fusiform obclavate (rarely nearly spherical), occasionally ornamented with longitudinal ridges on exterior; seeds without winglike margin, with coma (absent in some Sarcolobus, right around seed in Fockea sinuata). $\mathrm{x}=11$. Characteristic secondary compounds are "Asclepiadaceae bitter principles" (glycosides). Distribution: cosmopolitan, mainly subtropical to tropical.

Absolmsia Kuntze, Rev. Gen. 2: 417 (1891).

Anatropanthus Schltr., Bot. Jahrb. Syst. 40, Beibl. 92: 18 (1908).

Anisopus N. E. Br., Bull. Misc. Inform. 1895: 259 (1895).

Asterostemma Decne., Ann. Sci. Nat., Bot., sér. 2, 9: 371, t. 10 (1838).

Campestigma Pierre ex Costantin in Lecomte, Fl. Gén. Indo-Chine 4: 117 (1912).

Cathetostemma Blume, Rumphia 4: 30 (1849).

Cibirhiza Bruyns, Notes Roy. Bot. Gard. Edinburgh 45: 51 (1988).

Clemensiella Schltr., Repert. Spec. Nov. Regni Veg. 13: 566 (1915).

Cosmostigma Wight, Contr. Bot. India 41 (1834).

Dischidia R. Br., Prodr. 461 (1810).

Dolichopetalum Tsiang, Acta Bot. Sin. 15: 137 (1973).

Fockea Endl. in Endl. \& Fenzl, Nov. Stirp. Decades 17 (1839).

Gongronema (Endl.) Decne. in A. DC. Prodr. 8: 624 (1844).

Gunnessia P. I. Forst., Austrobaileya 3: 282 (1990).

Heynella Backer, Blumea 6: 381 (1950).

Hoya R. Br., Prodr. 459 (1810).

Lygisma Hook. f., Hook. Icon. Pl. 15: 18, t. 1423 (1883).

Madangia P. I. Forster, D. J. Liddle \& I. M. Liddle, Austrobaileya 5: 53 (1997).

Marsdenia R. Br., Prodr. 460 (1810), nom. cons.

Micholitzia N. E. Br., Bull. Misc. Inform. 1909: 358 (1909).

Oreosparte Schltr., Beih. Bot. Centralbl. 34: 16 (1916).

Pseusmagennetus Ruschenb., Rep. Cundurango 15 (1873).

Pycnorhachis Benth. in Benth. \& Hook., Gen. 2: 737 (1876).

Rhyssolobium E. Mey., Comment. Pl. Africae Austr. 217 (1838).

Sarcolobus R. Br., Asclepiadeae 23 (1810). 
Spirella Costantin in Lecomte, Fl. Gén. Indo-Chine 4: 78 (1912).

Stigmatorhynchus Schltr., Bot. Jahrb. Syst. 51: 141 (1913).

Telosma Coville, Contr. U.S. Natl. Herb. 9: 384 (1905).

Treutlera Hook. f., Hook. Icon. P1. 15: 20, t. 1425 (1883).

b. Ceropegieae Orb., Dict. Univ. Hist. Nat. 3: 339 (1843)

Herbs (rarely annuals: Conomitra), vines, or geophytes with subterranean tubers or stem succulents, with clear latex, rarely milky (especially Heterostemma). Leaf frequently reduced to minute, scalelike structure or spine, rarely with few colleters at juncture of apex of petiole and base of blade (Ceropegia, Heterostemma). Corolla rotate to variously tubular (urceolate to cylindrical; e.g., Ceropegia, Echidnopsis, Stapeliopsis), often fleshy, frequently with fleshy annulus around mouth of tube, often ornamented with papillae, hairs, or cilia; lobes with valvate aestivation, sometimes remaining fused at apices; corolline corona rarely present in sinuses of corolla lobes (Leptadenia). Anthers mostly hidden by corona lobes, erect to horizontal (rarely descending), sometimes lateral margins becoming membranous after dehiscence (rarely with membranous apical appendage: Caralluma), with guide rails below fertile part. Outer corona from 5 free-spreading lobes to partially or entirely fused into cup around column; inner corona usually of 5 free-ascending to erect lobes. Secondary nectaries sometimes on corona lobes. Pollinia erect to horizontal (rarely descending toward center of flower, e.g., Tavaresia), nearly spherical, ellipsoidal to D-shaped in outline and then strongly dorsiventrally flattened, with hyaline insertion crest along upper or outer margin through which pollen tubes emerge. Style head broad, with flat to concave (rarely convex or beaked) apex, usually much broader than tall, mostly sessile with ovaries somewhat embedded into indented base but occasionally tapering below via narrow neck into ovaries (e.g., Orbea, Macropetalum); corpuscle with flanks and floor and two spreading lateral wings to underside of which caudicles are attached. Follicles (sometimes only one by abortion) slender to stout fusiform; seeds usually surrounded by winglike margin; coma present. $\mathrm{x}=11$. Characteristic secondary compounds are "Asclepiadaceae bitter principles" (glycosides). Distribution: Old World, arid temperate, subtropics, tropics.

Anisotoma Fenzl, Linnaea 17: 330 (1844).

Brachystelma Sims, Bot. Mag. 49: ad t. 2343 (1822) (nom. cons.).

Caralluma R. Br., Asclepiadeae 14 (1810).

Ceropegia L., Sp. Pl. 1: 211 (1753).

Conomitra Fenzl in Endlicher \& Fenzl, Nov. Stirp. Decades 65 (1839).

Desmidorchis Ehrenb., Abh. Koenigl. Akad. Wiss. Berlin 1829: 31 (1832).

Dittoceras Hook. f., Hook. Icon. Pl. 15: t. 1422 (1883).

Duvalia Haw., Syn. Pl. Succ. 44 (1812).

Duvaliandra M. G. Gilbert, Cact. Succ. J. Gr. Brit. 42: 101 (1980).

Echidnopsis Hook. f., Bot. Mag. 97: t. 5930 (1871).

Edithcolea N. E. Br., Bull. Misc. Inform. 1895: 220 (1895).

Emplectanthus N. E. Br. in Thiselton-Dyer, Fl. Cap. 4 (1): 771 (1908).

Frerea Dalz., J. Linn. Soc., Bot. 8: 10, t. 3 (1864).

Heterostemma Wight \& Arn. in Wight, Contr. Bot. India 42 (1834).

Hoodia Sweet ex Decne. in A. DC., Prodr. 8: 664 (1844).

Huernia R. Br., Asclepiadeae 11 (1810).

Lavrania Plowes, Cact. Succ. J. (Los Angeles) 58: 122 (1986).

Leptadenia $\mathrm{R}$. Br., Asclepiadeae 23 (1810).

Macropetalum Burch. ex Decne. in A. DC., Prodr. 8: 626 (1844).

Neoschumannia Schltr., Bot. Jahrb. Syst. 38: 38 (1905). 
Notechidnopsis Lavranos \& Bleck, Cact. Succ. J. (Los Angeles) 57: 255 (1985).

Ophionella Bruyns, Cact. Succ. J. Gr. Brit. 43: 70 (1981).

Orbea Haw., Syn. Pl. Succ. 37 (1812).

Orthanthera Wight in Wight, Contr. Bot. India 48 (1834).

Pectinaria Haw., Suppl. PI. Succ. 14 (1819), nom. cons.

Pentasachme Wall. ex Wight in Wight, Contr. Bot. India 60 (1834).

Piaranthus R. Br., Asclepiadeae 12 (1810).

Pseudolithos P. R. O. Bally, Candollea 20: 41 (1965).

Quaqua N. E. Br., Gard. Chron., ser. 2, 12:8 (1879).

Rhytidocaulon P. R. O. Bally, Candollea 18: 335 (1962) (nom. cons.).

Riocreuxia Decne. in A. DC., Prodr. 8: 640 (1844).

Sisyranthus E. Mey., Comment. Pl. Africae Austr. 197 (1838).

Stapelia L., Sp. P1. 1: 217 (1753).

Stapelianthus Choux ex A. C. White \& B. Sloane, Stapelieae 71 (1933).

Stapeliopsis Pillans, S. African Gard. 18: 32 (1928).

Tavaresia Welw, Ann. Cons. Ultramarino, ser. 1: 79 (1854).

Tenaris E. Mey., Comment Pl. Africae Austr. 198 (1838).

Tridentea Haw., Syn. Pl. Succ. 34 (1812).

Tromotriche Haw., Syn. Pl. Succ. 36 (1812).

White-sloanea Chiov., Malpighia 34: 541 (1937).

\section{c. Asclepiadeae (R. Br.) Duby, Bot. Gall. 1: 323 (1828)}

Herbs, trees (up to $6 \mathrm{~m}$, Calotropis), vines, geophytes with subterranean tubers, occasionally succulents, with milky (rarely clear or yellow) latex. Leaves often with cluster of colleters adaxially at juncture of apex of petiole and base of leaf blade. Corolla rotate to occasionally tubular; lobes with valvate to imbricate aestivation; corolline corona rare, in sinuses of lobes (Araujia sericifera) or annular in Gonolobinae. Anthers generally erect to spreading, with deltoid apical appendage distinctly constricted at base, with guide rails alongside fertile part (rarely below: Karimbolea, some species of Tylophora, most Gonolobinae). Outer corona from 5 to 20 (Eustegia, Emicocarpus) minute, free, spreading to erect lobes to partially or entirely fused into cup, together with or free from inner lobes around column or annular (Gonolobinae), rarely absent; inner corona usually of 5 massive, free, often channeled lobes, often with additional lobules on adaxial surface (rarely partially fused with corolla, Parapodium) to small and adpressed to backs of anthers or absent (Pleurostelma, Stephanus, Microloma). Pollinia pendulous or rarely erect (Karimbolea), more or less horizontal (some species of Tylophora), small and more or less ellipsoidal to long narrow and dorsiventrally flattened, rarely with hyaline insertion crest along inner edge, Pergularia; on upper margin near attachment of caudicles, Gonolobinae; upper edge in some Schizoglossum or with caudicles attenuated into small apical spike (Oncinema), pollen tubes emerging through inner, upper edge or one concave face (Gonolobinae). Style head broad, with flat to concave (sometimes conical to slenderly conical) apex, tapering below into narrow neck above ovaries (more or less sessile in Eustegia, Emicocarpus); caudicles frequently with projecting hooks and ridges assisting in insertion of pollinium in guide rail; ovary apocarpous, mostly superior. Follicle (usually one by abortion) often extremely swollen (Araujia, Calotropis), rarely spherical, more usually fusiform obclavate, frequently ornamented with spinelike processes or protuberances or longitudinal ridges on exterior; seeds more or less elliptical in outline, without winglike margin, with coma (absent in Emicocarpus). $\mathrm{x}=11$ (rarely 10,9). Secondary compounds are "Asclepiadaceae bitter principles" (glycosides), more rarely cardenolides. Distribution: cosmopolitan, temperate to tropics. 
Acrocoryne Turcz., Bull. Soc. Imp. Naturalistes Moscou 25: 316 (1852).

Adelostemma Hook. f., Hook. Icon. Pl. 15, t. 1427 (1883).

Aidomene Stopp, Bot. Jahrb. Syst. 87: 21 (1967).

Amblyopetalum (Griseb.) Malme, Ark. Bot. 21 A: 17 (1927).

Amblystigma Benth. in Benth. \& Hook. f., Gen. 2: 748 (1876).

Ampelamus Raf., Amer. Monthly Mag. \& Crit. Rev. 4: 192 (1819).

Anomotassa K. Schum., Bot. Jahrb. Syst. 25: 730 (1898).

Araujia Brot., Trans. Linn. Soc. London 12: 62, t. 4-5 (1817).

Asclepias L. Sp. Pl. 1: 214 (1753).

Aspidoglossum E. Mey., Comment Pl. Africae Austr. 200 (1838).

Aspidonepsis Nicholas \& Goyder, Bothalia 22: 24 (1992).

Astephanus R. Br., Asclepiadeae 43 (1810).

Barjonia Decne. in A. DC. Prodr. 8: 512 (1844).

Biondia Schltr., Bot. Jahrb. Syst. 36, Beibl. 82: 91 (1905).

Blepharodon Decne. in A. DC., Prodr. 8: 603 (1844).

Blyttia Am. in Jardine \& Johnston, Mag. Zool. Bot. 2: 420 (1838).

Bustelma E. Fourn. in Martius, Fl. Brasil. 6(4): 287 (1885).

Calathostelma E. Foum. in Martius, Fl. Brasil. 6(4): 219 (1885).

Calostigma Decne., Ann. Sci. Nat., Bot. sér. 2, 9: 343, t. 12 (1838).

Calotropis R. Br., Asclepiadeae 28 (1810).

Cordylogyne E. Mey., Comment. Pl. Afticae Austr. 218 (1838).

Corollonema Schltr., Repert. Spec. Nov. Regni Veg. 13: 441 (1914).

Cyathella Decne., Ann. Sci. Nat., Bot. sér. 2, 9: 332 (1838)

Cyathostelma E. Fourn. in Martius, Fl. Brasil. 6(4): 219 (1885).

Cynanchum L., Sp. PI. 1: 212 (1753).

Dactylostelma Schltr., Oesterr. Bot. Z. 45: 452 (1895).

Dicarpophora Speg., Physis (Buenos Aires) 8: 269 (1926).

Dictyanthus Decne in A. DC., Prodr. 8: 604 (1844).

Diploglossum Meisn., PI. Vasc. Gen. 1: 269 (1840).

Diplolepis R. Br., Asclepiadeae 30 (1810).

Diplostigma K. Schum. in Engler, Pflanzenwelt Ost-Afrikas C 324 (1895).

Ditassa R. Br., Asclepiadeae 41 (1810).

Emicocarpus K. Schum. \& Schltr., Bot. Jahrb. Syst. 29, Beibl. 66: 21 (1900).

Eustegia R. Br., Asclepiadeae 40 (1810).

Fanninia Harv., Gen. S. African Pl., ed. 2: 235 (1868).

Fischeria DC., Cat. Horti Monspel. 112 (1813).

Folotsia Costantin \& Bois, Compt. Rend. Hebd. Séances Acad. Sci. 147: 258 (1908).

Funastrum E. Fourn., Ann. Sci. Nat. Bot., sér. 6, 14: 388 (1882).

Glossonema Decne., Ann. Sci. Nat., Bot. sér. 2, 9: 335 (1838).

Glossostelma Schltr., J. Bot. 33: 321 (1895).

Gomphocarpus R. Br., Asclepiadeae 26 (1810).

Gonioanthela Malme, Ark. Bot. 21A: 6 (1927).

Gonolobus Michx., Fl. Bor. Amer. 1: 119 (1803).

Goydera Liede, Novon 3: 265 (1993).

Graphistemma (Champ. ex Benth.) Champ. ex Benth. in Benth. \& Hook. f., Gen. 2: 760 (1876).

Grisebachiella Lorentz, Bot. Centralbl. 2: 1339 (1880).

Hemipogon Decne. in A. DC., Prodr. 8: 509 (1844).

Hickenia Lillo, Physis (Buenos Aires) 4: 422 (1919).

Holostemma R. Br., Asclepiadeae 31 (1810).

Husnotia E. Fourn. in Martius, Fl. Brasil. 6(4): 211 (1885).

Hypolobus E. Fourn. in Martius, Fl. Brasil. 6(4) 311 (1885).

Ibatia Decne in A. DC., Prodr. 8: 599 (1844).

Jobinia E. Fourn. in Martius, Fl. Brasil. 6(4): 327 (1885).

Kanahia R. Br., Asclepiadeae 28 (1810). 
Karimbolea Descoings, Cactus 15: 77 (1960).

Kerbera E. Fourn. in Martius, Fl. Brasil. 6(4): 290 (1885).

Labidostelma Schltr., Bull. Herb. Boissier, ser. 2, 6: 843 (1906).

Lachnostoma Kunth in Humboldt, Bonpl. \& Kunth, Nov. Gen. Sp. 3, ed. fol. 155; ed. qu. 198, t. 232 (1819).

Lagenia E. Fourn. in Martius, Fl. Brasil. 6(4): 293 (1885).

Lagoa T. Durand, Index Gen. Phan. 269 (1888).

Lorostelma E. Foum. in Martius, Fl. Brasil. 6(4): 220 (1885).

Lugonia Wedd., Chlor. Andina 2: 49 (1859).

Macroditassa Malme, Ark. Bot. 21A: 9 (1927).

Macroscepis Kunth in Humboldt, Bonpl. \& Kunth, Nov. Gen. Sp. 3, ed. 4: 198 (1819).

Mahawoa Schltr., Beih. Bot. Centralbl. 34: 2 (1916).

Margaretta Oliv., Trans. Linn. Soc. London 29: 111 (1875).

Matelea Aubl., Hist. Pl. Guiane 277, t. 109 (1775).

Melinia Decne. in A. DC., Prodr. 8: 588 (1844).

Meresaldia Bullock, Kew Bull. 19: 203 (1965).

Merrillanthus Chun \& Tsiang, Sunyatsenia 6: 105 (1941).

Metalepis Griseb., Cat. Pl. Cub. 179 (1866).

Metaplexis R. Br., Asclepiadeae 37 (1810).

Metastelma R. Br., Asclepiadeae 41 (1810).

Microloma R. Br., Asclepiadeae 42 (1810).

Miraglossum Kupicha, Kew Bull. 38: 625 (1984).

Mitostigma Decne. in A. DC., Prodr. 8: 507 (1844).

Morrenia Lindl., Edwards' Bot. Reg. 24: 71 (1838).

Nautonia Decne. in A. DC., Prodr. 8: 509 (1844).

Nematostemma Choux, Compt. Rend. Hebd. Séances Acad. Sci. 172: 1310 (1921).

Nematuris Turcz., Bull. Soc. Imp. Naturalistes Moscou 21: 254 (1848).

Nephradenia Decne. in A. DC., Prodr. 8: 604 (1844).

Odontanthera Wight, Madras J. Lit. Sci. 7: 143 (1838).

Odontostelma Rendle, J. Bot. 32: 161, 1895: 250 (1895).

Oncinema Arn., Edinburgh New Philos. J. 17: 261 (1834).

Orthosia Decne. in A. DC., Prodr. 8: 526 (1844).

Oxypetalum R. Br., Asclepiadeae 30 (1810), nom. cons.

Oxystelma R. Br., Prodr. 462 (1810).

Pachycarpus E. Mey., Comment. Pl. Africae Austr. 209 (1838).

Pachyglossum Decne., Ann. Sci. Nat., Bot., sér. 2, 9: 345 (1838).

Parapodium E. Mey., Comment. Pl. Africae Austr. 221 (1838).

Pentabothra Hook. f., Fl. Brit. India 4: 18 (1883).

Pentacyphus Schltr., Bot. Jahrb. Syst. 37: 605 (1906).

Pentarrhinum E. Mey., Comment. Pl. Africae Austr. 199 (1838).

Pentastelma Tsiang \& P. T. Li in Chun \& al., Fl. Hainan. 3: 577 (1974).

Pentatropis R. Br. ex Wight \& Arn. in Wight, Contr. Bot. India: 52 (1834).

Peplonia Decne. in A. DC., Prodr. 8: 545 (1844).

Pergularia L., Syst. Nat., ed. 12, 2: 135 (1767).

Petalostelma E. Fourn. in Martius, Fl. Brasil. 6(4): 328 (1885).

Pherotrichis Decne. Ann. Sci. Nat. (Paris), sér. 2, 9: 322 (1838).

Philibertia Kunth. in Humboldt, Bonpl. \& Kunth, Nov. Gen. Sp. 3, ed. fol. 152; ed. qu. 195, t. 230 (1819).

Platykeleba N. E. Br., Bull. Misc. Inform. 1895: 250 (1895).

Pleurostelma Baill., Hist. P1. 10: 266 (1890).

Podandra Baill., Hist. P1. 10: 265 (1890).

Polystemma Decne. in A. DC., Prodr. 8: 602 (1844).

Prosthecidiscus Donnell-Smith, Bot. Gaz. 25: 149 (1898).

Pycnostelma Bunge ex Decne. in A. DC., Prodr. 8: 512 (1844). 
Raphistemma Wall., Pl. Asiat. Rar. 2: 50 (1831).

Rhyncharrhena F. Muell., Fragm. 1: 128 (1859).

Rhyssostelma Decne. in A. DC., Prodr. 8: 590 (1844).

Rojasia Malme, Ark. Bot. 4: 10, t. 2 (1905).

Sarcostemma R. Br., Prodr. 463 (1810).

Sattadia E. Fourn. in Martius, Fl. Brasil. 6(4): 231 (1885).

Schistogyne Hook. \& Arn., J. Bot. (Hooker) 1: 292 (1834).

Schistonema Schltr., Bot. Jahrb. Syst. 37: 604 (1906).

Schizoglossum E. Mey., Comment. Pl. Africae Austr. 218 (1838).

Schizostemma Decne., Ann. Sci. Nat., Bot., sér. 2, 9: 344 (1838).

Schubertia Mart., Nov. Gen. Sp. 1: 55, t. 33 (1824), nom. cons.

Scyphostelma Baill., Hist. Pl. 10: 252 (1890).

Seshagiria Ansari \& Hemadri, Indian Forester 97: 126 (1971).

Seutera Rchb., Consp. 131 (1828).

Solenostemma Hayne, Getr. Darstellung Arzneyk. Gewächse 9, t. 38 (1825).

Sphaerocodon Benth. in Benth. \& Hook. f., Gen. 2: 772 (1876).

Stathmostelma K. Schum., Bot. Jahrb. Syst. 17: 129 (1893).

Steleostemma Schltr., Bot. Jahrb. Syst. 37: 603 (1906).

Stelmagonum Baill., Hist. Pl. 10: 287 (1890).

Stelmation E. Fourn. in Martius, Fl. Brasil. 6(4): 226 (1885).

Stelmatocodon Schltr., Bot. Jahrb. Syst. 37: 617 (1906).

Stenomeria Turcz., Bull. Soc. Imp. Naturalistes Moscou 25: 312 (1852).

Stenostelma Schltr., Bot. Jahrb. Syst. 18, Beibl. 45: 6 (1894).

Stuckertia Kuntze in Post \& Kuntze, Lex. 541 (1903).

Tassadia Decne. in A. DC., Prodr. 8: 579 (1844).

Telminostelma E. Fourn. in Martius, FI. Brasil. 6(4): 218 (1885).

Tetraphysa Schltr., Bot. Jahrb. Syst. 37: 616 (1906).

Trachycalymma (K. Schum.) Bullock, Kew Bull. 1953: 348 (1953).

Trichosacme Zucc., Abh. Math.-Phys. Cl. Koenigl. Bayer., Akad. Wiss. 4(2): 11 (1846).

Turrigera Decne. in A. DC., Prodr. 8: 590 (1844).

Tweedia Hook. \& Arn., J. Bot. (Hooker) 1: 291 (1834).

Tylophora R. Br., Prodr. 460 (1810).

Urostelma Bunge, Enum. PI. 44 (1833).

Vailia Rusby, Bull. Torrey Bot. Club 25: 500 (1898).

Vincetoxicopsis Costantin in Lecomte, Fl. Gén. Indo-Chine 4: 103 (1912).

Vincetoxicum Wolf, Gen. 130 (1776).

Widgrenia Malme, Kongl. Svenska Vetenskapsakad. Handl. 34: 69 (1900).

Woodia Schltr., Bot. Jahrb. Syst. 18, Beibl. 45: 30 (1894).

Xysmalobium R. Br., Asclepiadeae 27 (1810).

\section{Acknowledgments}

We thank Paul Forster, David Goyder, Toon Leeuwenberg, and David Middleton for providing valuable comments on the manuscript and Laure Civeyrel, Mark Fishbein, Jens Klackenberg, Gilberto Morillo, Jorge Fontella Pereira, Doug Stevens, Johan Venter, and Rudi Verhoeven for critically reviewing the lists of taxa. We also wish to thank Kurt Potgieter for providing unpublished molecular data, especially with regard to the "Plumerieae," and Siwert Nilsson for providing unpublished information on the pollen of Microplumeria. Much of the data for this classification were obtained using fixed flowers kindly donated by many colleagues over the years. These include: Paul Berry, Laure Civeyrel, Petra De Block, Larry Dorr, Urs Eggli, Valerio Ferreira, Paul Forster, Bill Haber, T.-C. Huang, Luiza Kinoshita, Henning Kunze, Toon Leeuwenberg, Sigrid Liede, David Lorence, Dave Neill, Gustavo Ro- 
mero, Roger Sanders, Jim Solomon, Shirley Tucker, Johan Venter, Rudi Verhoeven, Jim Zarucchi, and Scott Zona. We gratefully acknowledge their generosity.

\section{Literature Cited}

Allorge, L. 1975. Rattachement de la tribu des Allamandées aux Echitoïdées (Apocynacées). Adansonia, sér. 2, 15: 273-276.

Armbruster, W.S. 1996. Exaptation, adaptation, and homoplasy: Evolution of ecological traits in Dalechampia vines. Pp. 227-243 in M. J. Sanderson \& L. Hufford (eds.), Homoplasy: The recurrence of similarity in evolution. Academic Press, San Diego.

Bentham, G. 1876. Apocynaceae \& Asclepiadaceae. Pp. 681-785 in G. Bentham \& J. D. Hooker (eds.), Gen. Pl., vol. 2, part 2. L. Reeve, London.

Boke, N. H. 1948. Development of the perianth in Vinca rosea L. Amer. J. Bot. 35: 413-423.

Brown, N. E. 1902-1903. Asclepiadaceae. Pp. 231-503 in W. T. Thiselton-Dyer (ed.), Fl. Trop. Afr. 4(1). L. Reeve, London.

. 1907-1909. Asclepiadaceae. Pp. 518-1036 in W. T. Thiselton-Dyer (ed.), Fl. Cap. 4(1): L. Reeve, London.

Brown, R. 1810a. Prodromus Florae Novae Hollandiae et Insulae van Diemen. London. Reprinted in C.

G. D. Nees von Esenbeck (ed., 1827), Robert Brown's vermischte botanische Schriften 3, issued 1828 as a separate work, Nuremberg.

. $1810 \mathrm{~b}$. On the Asclepiadeae, a natural order of plants separated from the Apocineae of Jussieu. [Preprint of Mem. Wern. Nat. Hist. Soc. 1: 12-78 (1811)].

Brummitt, R. K. 1992. Vascular plant families and genera. Royal Botanic Gardens, Kew.

Bruyns, P. V. 1993. A revision of Hoodia and Lavrania (Asclepiadaceae-Stapelieae). Bot. Jahrb. Syst. 115: $145-270$.

1994. A note on Raphionacme namibiana. Aloe 31: 63-67.

1995. New records and new species of Asclepiadaceae from Namibia. Bothalia 25: 155-172.

1999. The systematic position of Eustegia. Bot. Jahrb. Syst. 121: 19-44.

\& P. I. Forster. 1991. Recircumscription of the Stapelieae (Asclepiadaceae). Taxon 40: $381-391$.

\& H. P. Linder. 1991. A revision of Microloma R. Br. (Asclepiadaceae-Asclepiadeae). Bot. Jahrb. Syst. 112: 453-527.

Bullock, A. A. 1956. Notes on African Asclepiadaceae--VIII. Kew Bull. 1956: 503-522. . 1963. Periplocaceae, Asclepiadaceae. Pp. 80-103 in J. Hutchinson \& J. M. Dalziel (eds.), Fl. W. Trop. Afr. Ed. 2. Millbank, London.

Civeyrel, L. 1994. Variation et évolution des types polliniques du genre Secamone (Secamonoideae, Asclepiadaceae). C. R. Acad. Sci., Paris, 317: 1159-1165.

1995. Pollen morphology and ultrastructure of the genus Secamone in Africa. 2d Symposium on African Palynology, Tervuren (Belgium), 1995, Publ. Occas. CIFEG, Orléans, CIFEG: 207215.

. 1996. Phylogenie des Asclepiadaceae: Approche palynologique et moleculaire. Ph.D. diss., Montpellier.

___ A. Le Thomas, K. Ferguson \& M. Chase. 1998. Critical reexamination of palynological characters used to delimit Asclepiadaceae in comparison to the molecular phylogeny obtained from plastid matK sequences. Molec. Phylogen. Evol. 9: 517-127.

Coppen, J. J. W. \& A. I. Cobb. 1983. The occurrence of iridoids in Plumeria and Allamanda. Phytochem. 22: 125-128.

Dannenbaum, C. \& R. Schill. 1991. Die Entwicklung der Pollentetraden und Pollinien bei den Asclepiadaceae. Biblioth. Bot. 141: 1-138.

Decaisne, J. 1844. Asclepiadaceae. Pp. 940-665 in A. P. De Candolle (ed.), Prodr. (DC.) 8. Paris.

De Kruif, A. P. M. 1981. A Revision of Holarrhena R. Br. (Apocynaceae). Meded. Landbouwhogeschool 81(2): 1-36.

Demeter, K. 1922. Vergleichende Asclepiadeenstudien. Flora 115: 130-176. 
Dyer, R. A. 1975. The genera of southern African flowering plants. 1. Dicotyledons. Govt. Printer, Pretoria.

Endlicher, S. L. 1838. Gen. P1. 8: 577-599 (Apocynaceae \& Asclepiadaceae). F. Beck, Vienna.

Endress, M. E. 1997. Key characters at the interface of the apocynacs and the asclepiads. Amer. J. Bot. 84 (6, Abstracts): 189.

\& V. A. Albert. 1995. A morphological cladistic study of Apocynaceae: Trends in character evolution within a broadened familial circumscription. Amer. J. Bot. 82 (6, Abstracts): 127.

, M. Hesse, S. Nilsson, A. Guggisberg \& J.-P. Zhu. 1990. The systematic position of the Holarrheninae (Apocynaceae). Pl. Syst. Evol. 171: 157-185.

- B. Sennblad, S. Nilsson, L. Civeyrel, M. Chase, S. Huysmans, E. Grafström \& B. Bremer, 1996. A phylogenetic analysis of Apocynaceae s.str. and some related taxa in Gentianales: A multidisciplinary approach. Opera Bot. Belg. 7: 59-102.

Endress, P. K. 1996. Homoplasy in angiosperm flowers. Pp. 303-325 in M. J. Sanderson \& L. Hufford (eds.), Homoplasy: The recurrence of similarity in evolution. Academic Press, San Diego.

Fallen, M. E. 1983a. A systematic revision of Anechites (Apocynaceae). Brittonia 25: 222-231.

. 1983b. A taxonomic revision of Condylocarpon (Apocynaceae). Ann. Missouri Bot. Gard. 70: 149-169.

1985. The gynoecial development and systematic position of Allamanda (Apocynaceae). Amer. J. Bot. 72: 572-579.

1986. Floral structure in the Apocynaceae: Morphological, functional, and evolutionary aspects. Bot. Jahrb. Syst. 106: 245-286.

Fishbein, M. \& R. Levin. 1997. Metastelma mexicanum (Asclepiadaceae): A new combination and reevaluation of the status of Basistelma Bartlett. Madrõno 44: 268-276.

Forster, P. I. 1991. The correct publication dates for some genera and species of Asclepiadaceae described by Robert Brown. Asklepios 52: 78-79.

-1995. Circumscription of Marsdenia (Asclepiadaceae: Marsdenieae), with a revision of the genus in Australia and Papuasia. Austral. Syst. Bot. 8: 703-933.

Goyder, D. J. 1992. Secamone (Asclepiadaceae subfam. Secamonoideae) in Africa. Kew Bull. 47: 437-474.

Hallier, H. 1905. Provisional scheme of the natural (phylogenetic) system of flowering plants. New Phytol. 4: 151-162.

Huber, H. 1973. Apocynaceae, Periplocaceae and Asclepiadaceae. Pp. 1-57 in B. A. Abeywickrama (ed.), A revised handbook to the flora of Ceylon, vol. 1, pt. 1. University of Sri Lanka Press, Colombo.

Hufford, L. 1997. The roles of ontogenetic evolution in the origins of floral homoplasies. Int. J. P1. Sci. 158 (Suppl. 6): S65-S80.

Hutchinson, J. 1973. The families of flowering plants. Ed. 3. Clarendon Press, Oxford.

Judd, W. S., R. W. Sanders \& M. J. Donoghue. 1994. Angiosperm family pairs: Preliminary phylogenetic analyses. Harvard Pap. Bot. 5: 1-51.

Jussieu, A. L. de. 1789. Genera Plantarum. Herissant, Paris.

Klackenberg, J. 1992a. Taxonomy of Secamone (Asclepiadaceae) in Asia and Australia. Kew Bull. 47: $595-612$.

1992b. Taxonomy of Secamone s. lat. (Asclepiadaceae) in the Madagascar Region. Opera Bot. 112: 5-127.

1995a. Malagasy Asclepiadaceae: Reinstatement of the genus Pervillea and two new combinations. Phytologia 78: 189-191.

- 1995b. Taxonomy and phylogeny of the SE Asian genus Genianthus (Asclepiadaceae). Bot. Jahrb. Syst. 117: 401-467.

1997a. Revision of the Malagasy genus Calyptranthera (Asclepiadaceae). Adansonia, sér. 3, 19: 21-37.

. 1997b. Revision of the genus Baroniella Costantin \& Gallaud (Asclepiadaceae, Periplocoideae). Candollea 52: 383-407.

. 1998. Taxonomy and phylogeny of the genus Camptocarpus s.l. Bot. Jahrb. Syst. 120: 45-85.

. 1999. Revision of the Malagasy genera Pentopetia and Ischnolepis (Apocynaceae s.l., Periplocoideae). Candollea 54: 257-339. 
Kunze, H. 1990. Morphology and evolution of the corona in Asclepiadaceae and related families. Trop. Subtrop. Pflanzenwelt 76: 1-51.

- 1993. Evolution of the translator in Periplocaceae and Asclepiadaceae. Pl. Syst. Evol. 185: 99-122.

1994. Ontogeny of the transiator in Asclepiadaceae s. str. Pl. Syst. Evol. 193: 223-242.

1995. Floral morphology of some Gonolobeae (Asclepiadaceae). Bot. Jahrb. Syst. 117:211-238.

.1996. Morphology of the stamen in the Asclepiadaceae and its systematic relevance. Bot. Jahrb. Syst. 118: 547-579.

, U. Meve \& S. Liede. 1994. Cibirhiza albersiana, a new species of Asclepiadaceae, and establishment of the tribe Fockeeae. Taxon 43: 367-376.

Kupicha, F. K. 1984. Studies in African Asclepiadaceae. Kew Bull. 38: 599-672.

Leeuwenberg, A. J. M. 1983. Some remarks on the taxonomy of the Plumerioideae (Apocynaceae). Bothalia 14: 799-801.

-. 1988. The Nerieae (Apocynaceae-Apocynoideae). Monogr. Syst. Bot. Missouri Bot. Gard. 25: $157-160$.

1991. A revision of Tabernaemontana: The Old World species. Whitstable Litho, Whitstable.

. 1994. Taxa of the Apocynaceae above the genus level. Series of revisions of Apocynaceae, XXXVIII. Wageningen Agric. Univ. Papers 94(3): 45-60.

. 1997. Series of revisions of Apocynaceae XLIV. Craspidospermum Boj. ex A. DC., Gonioma E. Mey., Mascarenhasia A. DC., Petchia Livera, Plectaneia Thou., and Stephanostegia Baill. Wageningen Agric. Univ. Papers 97(2): 1-124.

Liede, S. 1997. Subtribes and genera of the tribe Asclepiadeae (Apocynaceae, Asclepiadoideae)-A synopsis. Taxon 46: 233-247.

\& F. Albers. 1994. Tribal disposition of Asclepiadaceae genera. Taxon 43: 201-231.

\& H. Kunze, 1993. A descriptive system for corona analysis in the Asclepiadaceae. Pl. Syst. Evol. 185: 99-284.

- U. Meve \& P. G. Mahlberg. 1993. On the position of the genus Karimbolea Descoings. Amer. J. Bot. 80: 215-221.

Lý, T. D. 1986. Die Familie Apocynaceae Juss. in Vietnam. Teil 1. Allgemeiner Teil. Feddes Repert. 97: 235-273.

Mabberley, J. 1985. Jupiter Botanicus-Robert Brown of the British Museum. J. Cramer, Braunschweig.

Markgraf, F. 1974. Morphologische Kleinigkeiten mit grösseren Folgen. Phyton (Austria) 16: 105 116.

Meve, U. \& S. Liede. 1994. Floral biology and pollination in stapeliads-New results and a literature review. Pl. Syst. Evol. 192: 99-116.

Middleton, D. J. 1994. A revision of Urceola (Apocynaceae) in Thailand. Kew Bull. 49: 757-767.

. 1995. Baharuia: A new genus of Apocynaceae from Malesia. Blumea 40: 443-447.

- 1997a. A revision of Parsonsia R. Br. (Apocynaceae) in Malesia. Blumea 42: 191-248.

- 1997b. A revision of Carruthersia Seemann (Apocynaceae). Blumea 42: 489-498.

Nicholas, A. 1992. The asclepiadaceous works of Rudolf F. Schlechter (1872-1925). Willdenowia 22: 215-264.

\& H. Baijnath. 1994. A consensus classification for the order Gentianales with additional details on the suborder Apocynineae. Bot. Rev. (Lancaster) 60:440-482.

Nilsson, S. 1986. The significance of pollen morphology in the Apocynaceae. Pp. 359-374 in S. Blackmore \& I. K. Ferguson (eds.), Pollen and Spores: Form and Function. Academic Press, London. . 1990. Taxonomic and evolutionary significance of pollen in Apocynaceae. PI. Syst. Evol. Suppl. 5: 91-102.

- M. E. Endress \& E. Grafström. 1993. On the relationship of the Apocynaceae and Periplocaceac. Grana, Suppl. 2: 3-20.

Nishino, E. 1982. Corolla tube formation in six species of Apocynaceae. Bot. Mag. (Tokyo) 95: 1-17.

Omlor, R. 1996. Do Menabea venenata and Secamonopsis madagascariensis represent missing links between Periplocaceae, Secamonoideae and Marsdenieae (Asclepiadaceae)? Kew Bull. 51 : 695715. 
1998. Generische Revision der Marsdenieae (Asclepiadaceae). Ph.D. diss., Universităt Kaiserslautern.

Pichon, M. 1948a. Classification des Apocynacées. I. Carissées et Ambelaniées. Mém. Mus. Natl. Hist. Nat., sér. B, Bot. 24: 111-181.

1948b. Classification des Apocynacées. V. Cerbéroïdées. Not. Syst. Paris 13: 212-229.

- 1948c. Classification des Apocynacées. XIX. Le rétinacle des Echitoïdées. Bull. Soc. Bot. France 95: 211-216.

1949. Classification des Apocynacées. IX. Rauvolfiées, Alstoniées, Allamandées et Tabernaémontanoidées. Mém. Mus. Natl. Hist. Nat. 27: 153-251.

1950a. Classification des Apocynacées. XXV. Echitoidées. Mém. Mus. Natl. Hist. Nat., Sér. B, Bot. 1: 1-143.

- 1950b. Classification des Apocynacées. XXVIII. Supplément aux Plumérioïdées. Mém. Mus. Natl. Hist. Nat., Sér. B, Bot. 1: 145-173.

Potgieter, K. 1999. Phylogenetic study of Apocynaceae Juss. and Aspidosperma Mart. \& Zucc. Ph.D. diss., University of Illinois at Urbana-Champaign.

\&. V. A. Albert. 1997. Preliminary phylogenetic study of the genus Aspidosperma (Apocynaceae) and closely related genera using ITS and $t r n \mathrm{~L}-\mathrm{F}$ sequence data. Amer. J. Bot. 84 (6, Abstracts): 223.

- \& 1998a. Aspidosperma evolution based on cladistic analyses of morphological and molecular (ITS, trnL-F) sequence data. Amer. J. Bot. 85 (6, Abstracts): 151.

- $\&$ 1998b. Non-floral morphological correlates of the Apocynaceae s.s.-PeriplocaceaeAsclepiadaceae transition (i.e., dispersal traits) mapped onto a trnL-F derived consensus tree. Amer. J. Bot. 85 (6, Abstracts): 152.

Rosatti, T. J. 1989. The genera of suborder Apocynineae (Apocynaceae and Asclepiadaceae) in the southeastern United States. J. Arnold Arbor. 70: 307-401.

Rothe, W. 1915. Über die Gattung Marsdenia R. Br. und die Stammpflanze der Condurangorinde. Bot. Jahrb. Syst. 52: 354-434.

Safwat, F. M. 1962. The floral morphology of Secamone and the evolution of the pollinating apparatus in Asclepiadaceae. Ann. Missouri Bot. Gard. 49: 95-129.

Schill, R. \& U. Jäckel. 1978. Beitrag zur Kenntnis der Asclepiadaceen-Pollinarien. Trop. Subtrop. Pflanzenwelt 22: 1-122.

Schlechter, F. R. R. 1905. Periplocaceae \& Asclepiadaceae. Pp. 351-369 in K. Schumann \& K. Lauterbach (eds.), Nachtrăge zur Flora des Deutschen Südseegebiets. Borntraeger, Leipzig.

Schumann, K. 1895. A pocynaceae \& Asclepiadaceae. Pp. 109-305 in A. Engler \& K. Prantl (eds.), Nat. Pflanzenfam. 4(2). Engelmann, Leipzig.

Sennblad, B. 1997. Phylogeny of the Apocynaceae s.l. (Ph.D. dissertation summary). Acta Universitas Uppsaliensis. Comprehensive Summaries Uppsala Dissertations, Faculty of Science and Technology $295.18 \mathrm{pp}$. Uppsala.

\& B. Bremer. 1996. The familial and subfamilial relationships of Apocynaceae and Asclepiadaceae evaluated with $r b c \mathrm{~L}$ data. Pl. Syst. Evol. 202: 153-175.

, M. E. Endress \& B. Bremer. 1998. Morphology and molecular data in phylogenetic fraternity - The tribe Wrightieae (Apocynaceae) revisited. Amer. J. Bot. 85: 1143-1158.

Stapf, O. 1902. Apocynaceae. Pp. 24-231 in W. T. Thiselton-Dyer (ed.), Fl. Trop. Afr. 4(1). L. Reeve, London.

Stebbins, G. L. 1974. Flowering plants: Evolution above the species level. Belknap Press of Harvard University Press, Cambridge, MA.

Stevens, W. D. 1976. A revision of Matelea subg. Dictyanthus (Apocynaceae, sensu lato). Ph.D. diss., Michigan State University.

Struwe, L., V. A. Albert \& B. Bremer. 1994. Cladistics and family level classification of Gentianales. Cladistics 10: 175-206.

Swarupanandan, K., J. K. Mangaly, T. K. Sonny, K. Kishorekumar \& S. Chand Basha. 1996. The subfamilial and tribal classification of the family Asclepiadaceae. J. Linn. Soc., Bot. 120: 327-369.

Takhtajan, A. 1997. Diversity and classification of flowering plants. New York.

Thorne, R. F. 1976. A phylogenetic classification of the Angiospermae. Evol. Biol. 9: 35-106. 
1992. An updated phylogenetic classification of the flowering plants. Aliso 13: 365-389.

Tsiang, Y. 1934. Notes on Asiatic Apocynales. II. Sunyatsenia 2: 90-202.

Venter, H. J. T. \& R. L. Verhoeven. 1993. A taxonomic account of Stomatostemma (Periplocaceae). S. Afr. J. Bot. 59: 50-56.

1994. Buckollia, a new genus in the Periplocaceae. S. Afr. J. Bot. 60: 93-98.

1997. A tribal classification of the Periplocoideae (Apocynaceae). Taxon 46: 705-720.

Verhoeven, R. L. \& H. J. T. Venter. 1988. Pollen morphology of Raphionacme (Periplocaceae). S. Afr. J. Bot. 54: 123-132.

\& 1998. Pollinium structure in Periplocoideae (Apocynaceae). Grana 37: 1-14.

Vethacke, M. U. 1994. Systematische Untersuchungen an Gattungen der Tribus Gonolobeae (Asclepiadaceae). Diplomarbeit, Westfălische Wilhelms-Universität, Münster.

Woodson, R. E., Jr. 1930. Studies in the Apocynaceae. I. A critical study of the Apocynoideae (with special reference to the genus Apocynum). Ann. Missouri Bot. Gard. 17: 1-213.

1941. The North American Asclepiadaceae. 1. Perspective of the genera. Ann. Missouri Bot. Gard. 28: 193-244.

1951. Studies in the Apocynaceae. VIII. An interim revision of the genus Aspidosperma Mart. \& Zucc. Ann. Missouri Bot. Gard. 38: 119-207.

Zhu, J.-P., A. Guggisberg, M. Kalt-Hadamowsky \& M. Hesse. 1990. Chemotaxonomic study of the genus Tabernaemontana (Apocynaceae) based on their indole alkaloid content. P1. Syst. Evol. 172: 13-34. 